\title{
Single-step Synthesis of Pyrimidine Derivatives
}

\author{
Mohammad Movassaghi* and Matthew D. Hill \\ Massachusetts Institute of Technology, Department of Chemistry, Massachusetts 02139
}

\section{Contents:}

General Procedures $\quad$ S1

\begin{tabular}{ll} 
Materials & $\mathrm{S} 1$ \\
\hline
\end{tabular}

\begin{tabular}{ll} 
Instrumentation & $\mathrm{S} 2$ \\
\hline
\end{tabular}

Synthesis of pyrimidine derivatives: Table 2, entries 1-21 $\quad$ S3-S24

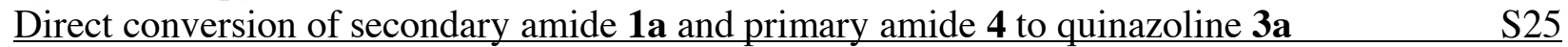

Reat-IR monitoring of the conversion of amide 1a and nitrile 2a to quinazoline 3a $\quad$ S26-S27

\begin{tabular}{lll}
${ }^{1} \mathrm{H}$ and ${ }^{19} \mathrm{~F}$ NMR monitoring of the conversion of amide 1a and nitrile 2a to quinazoline 3a & S28-S29 \\
\hline
\end{tabular}

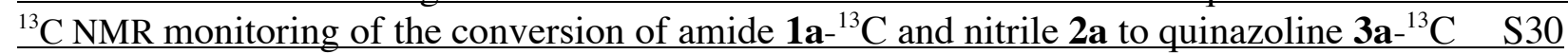

\begin{tabular}{ll} 
Additional notes on the mechanism (Scheme S1) & S30 \\
\hline
\end{tabular}

\section{Supporting Information}

General Procedures. All reactions were performed in oven-dried or flame-dried round bottomed flasks, modified Schlenk (Kjeldahl shape) flasks, or glass pressure vessels. The flasks were fitted with rubber septa and reactions were conducted under a positive pressure of argon. Stainless steel syringes or cannulae were used to transfer air- and moisture-sensitive liquids. Flash column chromatography was performed as described by Still et al. using silica gel (60- ̊ pore size, $32-63 \mu \mathrm{m}$, standard grade, Sorbent Technologies) or non-activated alumina gel (80-325 mesh, chromatographic grade, EM Science). ${ }^{1}$ Analytical thin-layer chromatography was performed using glass plates pre-

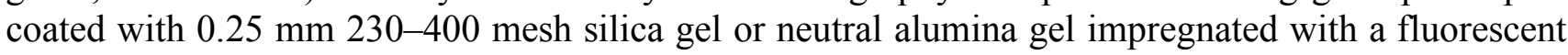
indicator $(254 \mathrm{~nm})$. Thin layer chromatography plates were visualized by exposure to ultraviolet light and/or by exposure to an ethanolic phosphomolybdic acid (PMA), an acidic solution of $p$ anisaldehyde (anis), an aqueous solution of ceric ammonium molybdate (CAM), an aqueous solution of potassium permanganate $\left(\mathrm{KMnO}_{4}\right)$ or an ethanolic solution of ninhydrin followed by heating $(<1$ min) on a hot plate $\left(\sim 250{ }^{\circ} \mathrm{C}\right)$. Organic solutions were concentrated on Büchi R-200 rotary evaporators at $\sim 10$ Torr (house vacuum) at $25-35^{\circ} \mathrm{C}$, then at $\sim 0.5$ Torr (vacuum pump) unless otherwise indicated.

Materials. Commercial reagents and solvents were used as received with the following exceptions: Dichloromethane, diethyl ether, tetrahydrofuran, acetonitrile, and toluene were purchased from J.T. Baker (Cycletainer ${ }^{\mathrm{TM}}$ ) and were purified by the method of Grubbs et al. under positive argon pressure. ${ }^{2}$ 2-chloropyridine was distilled from calcium hydride and stored sealed under an argon atmosphere. The starting amides were prepared by acylation of the corresponding anilines ${ }^{3}$ or via previously reported copper-catalyzed $\mathrm{C}-\mathrm{N}$ bond-forming reactions. ${ }^{4,5}$

\footnotetext{
${ }^{1}$ Still, W. C.; Kahn, M.; Mitra, A. J. Org. Chem. 1978, 43, 2923-2925.

${ }^{2}$ Pangborn, A. B.; Giardello, M. A.; Grubbs, R. H.; Rosen, R. K.; Timmers, F. J. Organometallics 1996, 15, 1518-1520.

${ }^{3}$ For a general procedure, see: DeRuiter, J.; Swearingen, B. E,; Wandrekar, V.; Mayfield, C. A. J. Med. Chem. 1989, 32, $1033-1038$.

${ }^{4}$ For the general procedure used for the synthesis of all $N$-vinyl amides, see: Jiang, L.; Job, G. E.; Klapars, A.; Buchwald, S. L. Org. Lett. 2003, 5, 3667-3669.

${ }^{5}$ For related reports, see: (a) Wolfe, J. P.; Wagaw, S.; Marcoux, J.-F.; Buchwald, S. L. Acc. Chem. Res. 1998, 31, 805-818. (b) Hartwig, J. F. Acc. Chem. Res. 1998, 31, 852-860. (c) Muci, A. R.; Buchwald, S. L. Top. Curr. Chem. 2002, 219, 131-209. (d) Beletskaya, I. P.; Cheprakov, A. V. Coordin. Chem. Rev. 2004, 248, 2337-2364. (e) Dehli, J. R.; Legros, J.; Bolm, C. Chem. Commun. 2005, $973-986$.
} 
Instrumentation. All reaction conducted at $140{ }^{\circ} \mathrm{C}$ were performed in a CEM Discover Lab Mate microwave reactor. Proton nuclear magnetic resonance $\left({ }^{1} \mathrm{H}\right.$ NMR) spectra were recorded with a Varian inverse probe 500 INOVA spectrometer. Chemical shifts are recorded in parts per million from internal tetramethylsilane on the $\delta$ scale and are referenced from the residual protium in the NMR solvent $\left(\mathrm{CHCl}_{3}: \delta 7.27, \mathrm{C}_{6} \mathrm{HD}_{5}: \delta 7.16, \mathrm{CHDCl}_{2}: \delta 5.32\right)$. Data is reported as follows: chemical shift [multiplicity ( $\mathrm{s}=$ singlet, $\mathrm{d}=$ doublet, $\mathrm{q}=$ quartet, $\mathrm{m}=$ multiplet), coupling constant(s) in Hertz, integration, assignment]. Carbon-13 nuclear magnetic resonance spectra were recorded with a Varian 500 INOVA spectrometer and are recorded in parts per million from internal tetramethylsilane on the $\delta$ scale and are referenced from the carbon resonances of the solvent $\left(\mathrm{CDCl}_{3}: \delta 77.2\right.$, benzene- $d_{6}: \delta$ 128.0, DMF- $\left.d_{7}: \delta 163.2, \mathrm{CD}_{2} \mathrm{Cl}_{2}: \delta 54.0\right)$. Data is reported as follows: chemical shift [multiplicity $(\mathrm{s}=$ singlet, $\mathrm{d}=$ doublet, $\mathrm{q}=$ quartet, $\mathrm{m}=$ multiplet), coupling constant(s) in Hertz, assignment]. Fluorine19 nuclear magnetic resonance spectra were recorded with a Varian 300 INOVA spectrometer and are recorded in parts per million on the $\delta$ scale and are referenced from the fluorine resonances of trifluoroacetic acid $\left(\mathrm{CD}_{2} \mathrm{Cl}_{2}: \delta-76.6\right)$. Data is reported as follows: chemical shift [multiplicity ( $\mathrm{s}=$ singlet, $\mathrm{d}=$ doublet, $\mathrm{q}=$ quartet, quint $=$ quintet, $\mathrm{m}=$ multiplet), coupling constant(s) in Hertz, assignment]. Infrared data were obtained with a Perkin-Elmer 2000 FTIR and are reported as follows: [frequency of absorption $\left(\mathrm{cm}^{-1}\right)$, intensity of absorption $(\mathrm{s}=$ strong, $\mathrm{m}=$ medium, $\mathrm{w}=\mathrm{weak}$, br $=$ broad), assignment]. In situ IR reaction monitoring was performed on an ASI ReactIR 1000 spectrometer. Chiral HPLC analysis was performed on an Agilent 1100 Series HPLC with a Chiralpak AD-H column. We thank Dr. Li Li at the Massachusettes Institute of Technology Department of Chemistry instrumentation facility for obtaining mass spectroscopic data. 

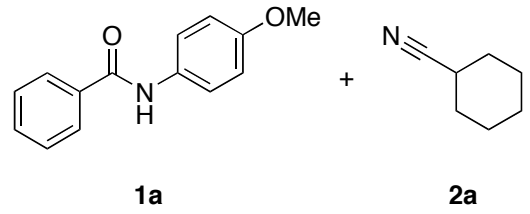

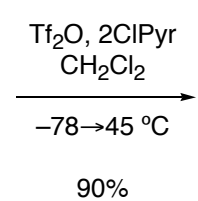

$90 \%$

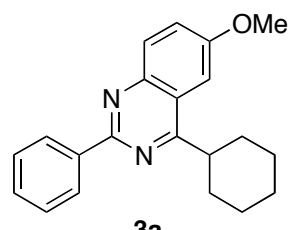

$3 a$

\section{4-Cyclohexyl-6-methoxy-2-phenyl-quinazoline (3a, Table 2, entry 1):}

Trifluoromethanesulfonic anhydride $(92 \mu \mathrm{L}, 0.56 \mathrm{mmol}, 1.1$ equiv) was added via syringe over $1 \mathrm{~min}$ to a stirred mixture of amide $1 \mathrm{a}(115 \mathrm{mg}, 0.506 \mathrm{mmol}, 1$ equiv) and 2-chloropyridine (58 $\mu \mathrm{L}, 0.61 \mathrm{mmol}, 1.2$ equiv) in dichloromethane $(1.7 \mathrm{~mL})$ at $-78^{\circ} \mathrm{C}$. After $5 \mathrm{~min}$, the reaction mixture was placed in an ice-water bath and warmed to $0{ }^{\circ} \mathrm{C}$, the nitrile $2 \mathbf{a}(61 \mathrm{mg}, 0.56 \mathrm{mmol}, 1.1$ equiv) was added via syringe, and the resulting solution was allowed to warm to ambient temperature for 5 minutes before the reaction vessel was placed into a preheated oil bath at $45^{\circ} \mathrm{C}$ and maintained at that temperature. After $16 \mathrm{~h}$, the reaction mixture was allowed to cool to ambient temperature and aqueous sodium hydroxide solution $(1 \mathrm{~mL}, 1 \mathrm{~N})$ was introduced to neutralize the trifluoromethanesulfonate salts. Dichloromethane $(5 \mathrm{~mL})$ was added to dilute the mixture and the layers were separated. The organic layer was washed with brine $(2 \mathrm{~mL})$, was dried over anhydrous sodium sulfate, and was filtered. The volatiles were removed under reduced pressure and the residue was purified by flash column chromatography (eluent: $7.5 \%$ EtOAc in hexanes; $\mathrm{SiO}_{2}: 15 \times 1.5 \mathrm{~cm}$ ) on neutralized silica gel to give the quinazoline product 3a as a white solid (145 $\mathrm{mg}, 90 \%)$.

${ }^{1} \mathrm{H}$ NMR $\left(500 \mathrm{MHz}, \mathrm{CDCl}_{3}, 20^{\circ} \mathrm{C}\right) \delta:$

${ }^{13} \mathrm{C}$ NMR $\left(125 \mathrm{MHz}, \mathrm{CDCl}_{3}, 20^{\circ} \mathrm{C}\right) \delta$ :

FTIR (neat) $\mathrm{cm}^{-1}$ :

HRMS (ESI):

TLC (15\% EtOAc/hexanes), $R_{\mathrm{f}}$ :
8.67-8.63 (m, 2H, ArH), $8.02(\mathrm{~d}, 1 \mathrm{H}, J=9.1 \mathrm{~Hz}, \operatorname{ArH})$, 7.56-7.46 (m, 4H, ArH), 7.37 (d, 1H, $J=2.6 \mathrm{~Hz}, \operatorname{ArH})$, $4.00\left(\mathrm{~s}, 3 \mathrm{H}, \mathrm{OCH}_{3}\right), 3.49(\mathrm{tt}, 1 \mathrm{H}, J=11.1,3.3 \mathrm{~Hz}$, $\left.{ }^{c} \mathrm{C}_{6} \mathbf{H}_{11}\right), 2.09-1.84\left(\mathrm{~m}, 7 \mathrm{H},{ }^{c} \mathrm{C}_{6} \mathbf{H}_{11}\right), 1.64-1.52(\mathrm{~m}, 2 \mathrm{H}$, ${ }^{c} \mathrm{C}_{6} \mathbf{H}_{11}$ ), 1.45 (qt, $1 \mathrm{H}, J=12.7,2.8 \mathrm{~Hz},{ }^{c} \mathrm{C}_{6} \mathbf{H}_{11}$ ).

$173.0,158.6,157.9,147.2,139.0,131.3,130.1,128.6$, $128.4,125.4,122.6,102.3,55.9,41.7,32.1,26.8,26.4$.

3064 (w), 2931 (m), 2852 (w), $1622(\mathrm{w}), 1567$ (w), 1546 (s), $1222(\mathrm{~s})$.

calcd for $\mathrm{C}_{21} \mathrm{H}_{23} \mathrm{~N}_{2} \mathrm{O}[\mathrm{M}+\mathrm{H}]^{+}$: 319.1810, found: 319.1807 .

0.50 (UV, CAM). 

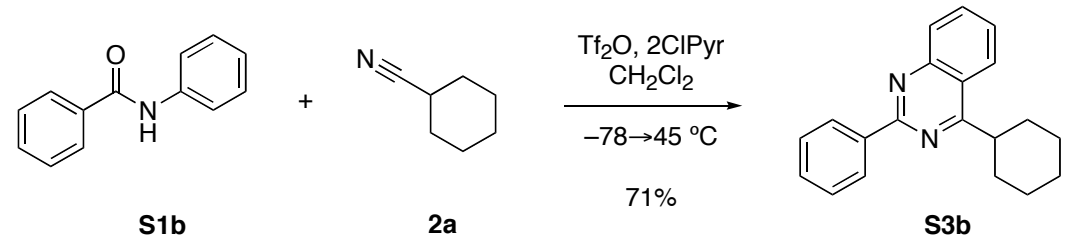

\section{4-Cyclohexyl-2-phenyl-quinazoline (S3b, Table 2, entry 2):}

Trifluoromethanesulfonic anhydride $(92 \mu \mathrm{L}, 0.56 \mathrm{mmol}, 1.1$ equiv) was added via syringe over $1 \mathrm{~min}$ to a stirred mixture of amide S1b (100 mg, $0.507 \mathrm{mmol}, 1$ equiv) and 2-chloropyridine $\left(57 \mu \mathrm{L}, 0.61 \mathrm{mmol}, 1.2\right.$ equiv) in dichloromethane $(1.7 \mathrm{~mL})$ at $-78^{\circ} \mathrm{C}$. After $5 \mathrm{~min}$, the reaction mixture was placed in an ice-water bath and warmed to $0{ }^{\circ} \mathrm{C}$, the nitrile $2 \mathbf{2 a}(61 \mathrm{mg}, 0.56 \mathrm{mmol}, 1.1$ equiv) was added via syringe, and the resulting solution was allowed to warm to ambient temperature for 5 minutes before the reaction vessel was placed into a preheated oil bath at $45^{\circ} \mathrm{C}$ and maintained at that temperature. After $16 \mathrm{~h}$, the reaction mixture was allowed to cool to ambient temperature and aqueous sodium hydroxide solution $(1 \mathrm{~mL}, 1 \mathrm{~N})$ was introduced to neutralize the trifluoromethanesulfonate salts. Dichloromethane $(5 \mathrm{~mL})$ was added to dilute the mixture and the layers were separated. The organic layer was washed with brine $(2 \mathrm{~mL})$, was dried over anhydrous sodium sulfate, and was filtered. The volatiles were removed under reduced pressure and the residue was purified by flash column chromatography (eluent: $5 \%$ EtOAc in hexanes; $\mathrm{SiO}_{2}: 15 \times 1.5 \mathrm{~cm}$ ) on neutralized silica gel to give the quinazoline product $\mathbf{S 3 b}$ as a white solid (104 $\mathrm{mg}, 71 \%$ ).

${ }^{1} \mathrm{H}$ NMR $\left(500 \mathrm{MHz}, \mathrm{CDCl}_{3}, 20{ }^{\circ} \mathrm{C}\right) \delta$ :

${ }^{13} \mathrm{C}$ NMR $\left(125 \mathrm{MHz}, \mathrm{CDCl}_{3}, 20^{\circ} \mathrm{C}\right) \delta$ :

FTIR (neat) $\mathrm{cm}^{-1}$ :

HRMS (ESI):

TLC (15\% EtOAc/hexanes), $R_{\mathrm{f}}$ :
8.72-8.67 (m, 2H, ArH), $8.18(\mathrm{dd}, 1 \mathrm{H}, J=8.3,1.3 \mathrm{~Hz}$, ArH), 8.10 (dd, $1 \mathrm{H}, J=8.5,1.3 \mathrm{~Hz}, \mathrm{ArH}), 7.86$ (ddd, $1 \mathrm{H}, J=8.3,6.9,1.3 \mathrm{~Hz}, \operatorname{ArH}), 7.61-7.48$ (m, 4H, ArH), 3.60 (tt, $\left.1 \mathrm{H}, J=11.2,3.4 \mathrm{~Hz},{ }^{c} \mathrm{C}_{6} \mathbf{H}_{11}\right), 2.09-1.84(\mathrm{~m}, 7 \mathrm{H}$, $\left.{ }^{c} \mathrm{C}_{6} \mathbf{H}_{11}\right), 1.62-1.52\left(\mathrm{~m}, 2 \mathrm{H},{ }^{c} \mathrm{C}_{6} \mathbf{H}_{11}\right), 1.45$ (qt, $1 \mathrm{H}, J=$ $\left.12.8,3.0 \mathrm{~Hz},{ }^{c} \mathrm{C}_{6} \mathbf{H}_{11}\right)$.

$174.9,160.2,151.2,138.9,133.3,130.5,129.8,128.8$, $128.7,126.8,124.3,121.9,41.7,32.3,26.8,26.4$.

3066 (w), 2933 (s), 2852 (s), 1615 (m), 1570 (s), 1546 (s), 1497 (s), 1344 (s), 1027 (m).

calcd for $\mathrm{C}_{20} \mathrm{H}_{21} \mathrm{~N}_{2}[\mathrm{M}+\mathrm{H}]^{+}$: 289.1705, found: 289.1704 .

$0.56(\mathrm{UV}, \mathrm{CAM})$. 

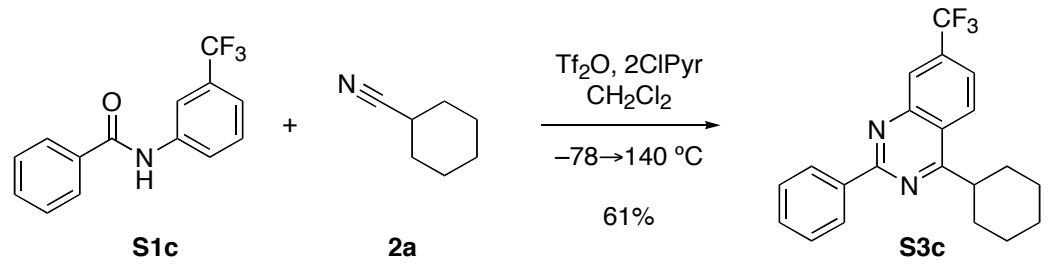

4-Cyclohexyl-2-phenyl-7-trifluoromethyl-quinazoline (S3c, Table 2, entry 3):

Trifluoromethanesulfonic anhydride $(82 \mu \mathrm{L}, 0.50 \mathrm{mmol}, 1.1$ equiv) was added via syringe over $1 \mathrm{~min}$ to a stirred mixture of amide $\mathbf{S 1 c}$ (120 $\mathrm{mg}, 0.450 \mathrm{mmol}, 1$ equiv) and 2-chloropyridine (51 $\mu \mathrm{L}, 0.54 \mathrm{mmol}, 1.2$ equiv) in dichloromethane $(1.5 \mathrm{~mL})$ at $-78^{\circ} \mathrm{C}$. After $5 \mathrm{~min}$, the reaction mixture was placed in an ice-water bath and warmed to $0{ }^{\circ} \mathrm{C}$, the nitrile $2 \mathrm{a}(54 \mathrm{mg}, 0.50 \mathrm{mmol}, 1.1$ equiv) was added via syringe, and the resulting solution was allowed to warm to ambient temperature for 5 minutes before the reaction vessel was placed into a microwave reactor and heated to $140^{\circ} \mathrm{C}$. After $20 \mathrm{~min}$, the reaction vessel was removed from the microwave reactor and allowed to cool to ambient temperature before aqueous sodium hydroxide solution $(1 \mathrm{~mL}, 1 \mathrm{~N})$ was introduced to neutralize the trifluoromethanesulfonate salts. Dichloromethane $(5 \mathrm{~mL})$ was added to dilute the mixture and the layers were separated. The organic layer was washed with brine $(2 \mathrm{~mL})$, was dried over anhydrous sodium sulfate, and was filtered. The volatiles were removed under reduced pressure and the residue was purified by flash column chromatography (eluent: $5 \%$ EtOAc in hexanes; $\mathrm{SiO}_{2}: 15 \times 1.5 \mathrm{~cm}$ ) on neutralized silica gel to give the quinazoline product $\mathbf{S 3 c}$ as a white solid $(97 \mathrm{mg}, 61 \%)$.

${ }^{1} \mathrm{H} \mathrm{NMR}\left(500 \mathrm{MHz}, \mathrm{CDCl}_{3}, 2{ }^{\circ} \mathrm{C}\right) \delta$ :

${ }^{13} \mathrm{C}$ NMR $\left(125 \mathrm{MHz}, \mathrm{CDCl}_{3}, 20{ }^{\circ} \mathrm{C}\right) \delta$ :

FTIR (neat) $\mathrm{cm}^{-1}$ :

HRMS (ESI):

TLC (20\% EtOAc/hexanes), $R_{\mathrm{f}}$ :

nOe data:
8.72-8.69 (m, 2H, ArH), 8.40 (s, 1H, ArH), $8.29(\mathrm{~d}, 1 \mathrm{H}$, $J=8.7 \mathrm{~Hz}, \operatorname{ArH}), 7.74(\mathrm{~d}, 1 \mathrm{H}, J=8.7 \mathrm{~Hz}, \operatorname{ArH}), 7.59$ $7.54(\mathrm{~m}, 3 \mathrm{H}, \mathrm{ArH}), 3.60(\mathrm{tt}, 1 \mathrm{H}, J=11.4,3.4 \mathrm{~Hz}$, $\left.{ }^{c} \mathrm{C}_{6} \mathbf{H}_{11}\right), 2.10-1.86\left(\mathrm{~m}, 7 \mathrm{H},{ }^{c} \mathrm{C}_{6} \mathbf{H}_{11}\right), 1.64-1.53(\mathrm{~m}, 2 \mathrm{H}$, $\left.{ }^{c} \mathrm{C}_{6} \mathbf{H}_{11}\right), 1.45$ (qt, $1 \mathrm{H}, J=12.7,3.0 \mathrm{~Hz},{ }^{c} \mathrm{C}_{6} \mathbf{H}_{11}$ ).

175.4, 161.3, 150.6, 138.1, $134.8(\mathrm{q}, J=33 \mathrm{~Hz}), 131.1$, $131.0,128.9,128.8,127.7$ (q, $J=4.3 \mathrm{~Hz}), 125.7,123.8$ $(\mathrm{q}, J=271 \mathrm{~Hz}), 123.1,122.3(\mathrm{q}, J=4.1 \mathrm{hz}), 42.0,32.3$, 26.7, 26.3.

2929 (s), 2857 (m), 1575 (s), 1549 (s), 1499 (m), 1344 (s), $1126(\mathrm{~s})$.

calcd for $\mathrm{C}_{21} \mathrm{H}_{20} \mathrm{~F}_{3} \mathrm{~N}_{2}[\mathrm{M}+\mathrm{H}]^{+}$: 357.1579, found: 357.1587 .

0.74 (UV, CAM).

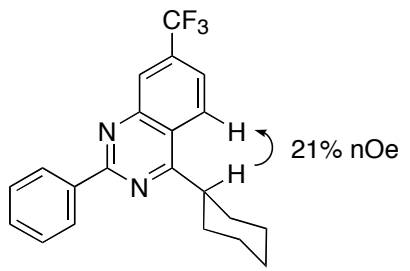



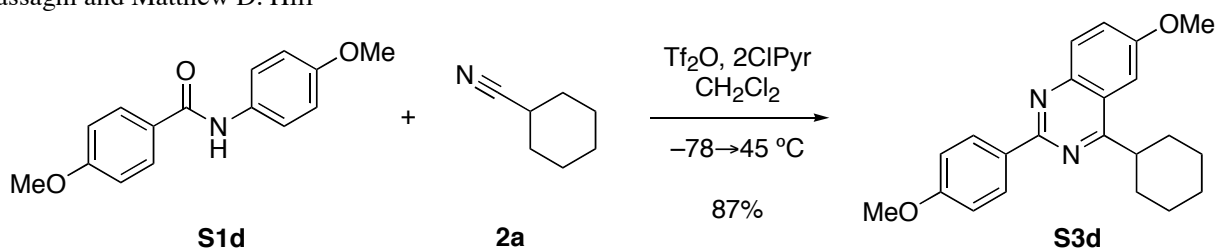

\section{4-Cyclohexyl-6-methoxy-2-(4-methoxy-phenyl)-quinazoline (S3d, Table 2, entry 4):}

Trifluoromethanesulfonic anhydride $(71 \mu \mathrm{L}, 0.43 \mathrm{mmol}, 1.1$ equiv) was added via syringe over $1 \mathrm{~min}$ to a stirred mixture of amide S1d (100 $\mathrm{mg}, 0.389 \mathrm{mmol}, 1$ equiv) and 2-chloropyridine (44 $\mu \mathrm{L}, 0.47 \mathrm{mmol}, 1.2$ equiv) in dichloromethane $\left(1.3 \mathrm{~mL}\right.$ ) at $-78^{\circ} \mathrm{C}$. After $5 \mathrm{~min}$, the reaction mixture was placed in an ice-water bath and warmed to $0{ }^{\circ} \mathrm{C}$, the nitrile $\mathbf{2 a}(47 \mathrm{mg}, 0.43 \mathrm{mmol}, 1.1$ equiv) was added via syringe, and the resulting solution was allowed to warm to ambient temperature for 5 minutes before the reaction vessel was placed into a preheated oil bath at $45^{\circ} \mathrm{C}$ and maintained at that temperature. After $18 \mathrm{~h}$, the reaction mixture was allowed to cool to ambient temperature and aqueous sodium hydroxide solution $(1 \mathrm{~mL}, 1 \mathrm{~N})$ was introduced to neutralize the trifluoromethanesulfonate salts. Dichloromethane $(5 \mathrm{~mL})$ was added to dilute the mixture and the layers were separated. The organic layer was washed with brine $(2 \mathrm{~mL})$, was dried over anhydrous sodium sulfate, and was filtered. The volatiles were removed under reduced pressure and the residue was purified by flash column chromatography (eluent: $10 \%$ EtOAc in hexanes; $\mathrm{SiO}_{2}: 15 \times 1.5 \mathrm{~cm}$ ) on neutralized silica gel to give the quinazoline product S3d as a white solid (118 $\mathrm{mg}, 87 \%)$.

${ }^{1} \mathrm{H}$ NMR $\left(500 \mathrm{MHz}, \mathrm{CDCl}_{3}, 20{ }^{\circ} \mathrm{C}\right) \delta: \quad 8.62-8.58(\mathrm{~m}, 2 \mathrm{H}, \mathrm{ArH}), 7.97(\mathrm{~d}, 1 \mathrm{H}, J=9.1 \mathrm{~Hz}, \mathrm{ArH})$, $7.50(\mathrm{dd}, 1 \mathrm{H}, J=9.1,2.7 \mathrm{~Hz}, \operatorname{ArH}), 7.35(\mathrm{~d}, 1 \mathrm{H}, J=2.7$ $\mathrm{Hz}, \mathrm{ArH}), 7.06-7.03$ (m, 2H, ArH), 3.99 (s, 3H, OCH $)_{3}$, $3.91\left(\mathrm{~s}, 3 \mathrm{H}, \mathrm{OCH}_{3}\right), 3.46(\mathrm{tt}, 1 \mathrm{H}, J=11.2,3.2 \mathrm{~Hz}$, $\left.{ }^{c} \mathrm{C}_{6} \mathbf{H}_{11}\right), 2.08-1.84\left(\mathrm{~m}, 7 \mathrm{H},{ }^{c} \mathrm{C}_{6} \mathbf{H}_{11}\right), 1.62-1.51(\mathrm{~m}, 2 \mathrm{H}$, $\left.{ }^{c} \mathrm{C}_{6} \mathbf{H}_{11}\right), 1.45$ (qt, $1 \mathrm{H}, J=12.7,3.2 \mathrm{~Hz},{ }^{c} \mathrm{C}_{6} \mathbf{H}_{11}$ ).

${ }^{13} \mathrm{C}$ NMR $\left(125 \mathrm{MHz}, \mathrm{CDCl}_{3}, 20^{\circ} \mathrm{C}\right) \delta:$

FTIR (neat) $\mathrm{cm}^{-1}$ :

HRMS (ESI):

TLC (20\% EtOAc/hexanes), $R_{\mathrm{f}}$ :
$172.9,161.4,158.4,157.6,147.2,131.7,131.0,129.9$, $125.3,122.2,113.9,102.4,55.8,55.5,41.7,32.0,26.8$, 26.4 .

$3001(\mathrm{w}), 2932$ (s), 2852 (w), 1623 (m), 1545 (s), 1515 (s), $1250(\mathrm{~s}), 1223$ (s), 1167(s).

calcd for $\mathrm{C}_{22} \mathrm{H}_{25} \mathrm{~N}_{2} \mathrm{O}_{2}[\mathrm{M}+\mathrm{H}]^{+}$: 349.1916, found: 349.1913.

0.45 (UV, CAM). 

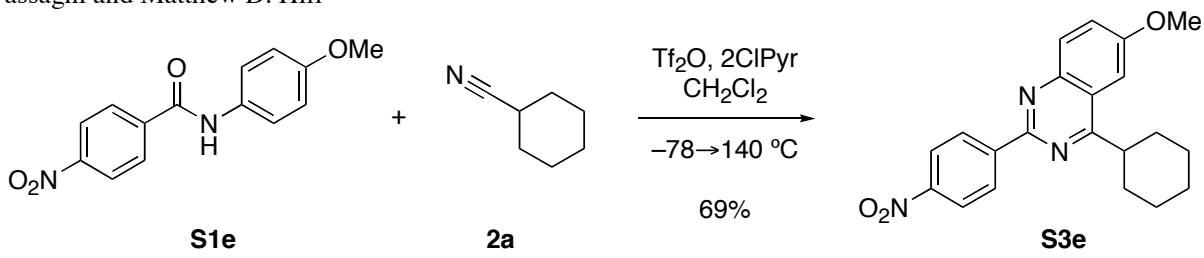

\section{4-Cyclohexyl-6-methoxy-2-(4-nitro-phenyl)-quinazoline (S3e, Table 2, entry 5):}

Trifluoromethanesulfonic anhydride $(80 \mu \mathrm{L}, 0.49 \mathrm{mmol}, 1.1$ equiv) was added via syringe over $1 \mathrm{~min}$ to a stirred mixture of amide S1e (120 mg, $0.440 \mathrm{mmol}, 1$ equiv) and 2-chloropyridine (50 $\mu \mathrm{L}, 0.53 \mathrm{mmol}, 1.2$ equiv) in dichloromethane $(1.5 \mathrm{~mL})$ at $-78^{\circ} \mathrm{C}$. After $5 \mathrm{~min}$, the reaction mixture was placed in an ice-water bath and warmed to $0{ }^{\circ} \mathrm{C}$, the nitrile $2 \mathbf{a}(53 \mathrm{mg}, 0.49 \mathrm{mmol}, 1.1 \mathrm{equiv})$ was added via syringe, and the resulting solution was allowed to warm to ambient temperature for 5 minutes before the reaction vessel was placed into a microwave reactor and heated to $140{ }^{\circ} \mathrm{C}$. After $20 \mathrm{~min}$, the reaction vessel was removed from the microwave reactor and allowed to cool to ambient temperature before aqueous sodium hydroxide solution $(1 \mathrm{~mL}, 1 \mathrm{~N})$ was introduced to neutralize the trifluoromethanesulfonate salts. Dichloromethane $(5 \mathrm{~mL})$ was added to dilute the mixture and the layers were separated. The organic layer was washed with brine $(2 \mathrm{~mL})$, was dried over anhydrous sodium sulfate, and was filtered. The volatiles were removed under reduced pressure and the residue was purified by flash column chromatography (eluent: $10 \%$ EtOAc in hexanes; $\mathrm{SiO}_{2}: 15 \times 1.5 \mathrm{~cm}$ ) on neutralized silica gel to give the quinazoline product S3e as a yellow solid (111 $\mathrm{mg}, 69 \%)$.

${ }^{1} \mathrm{H}$ NMR $\left(500 \mathrm{MHz}, \mathrm{CDCl}_{3}, 20{ }^{\circ} \mathrm{C}\right) \delta: \quad 8.84-8.81(\mathrm{~m}, 2 \mathrm{H}, \mathrm{ArH}), 8.38-8.35(\mathrm{~m}, 2 \mathrm{H}, \operatorname{ArH}), 8.05$ $(\mathrm{d}, 1 \mathrm{H}, J=9.1 \mathrm{~Hz}, \operatorname{ArH}), 7.57(\mathrm{dd}, 1 \mathrm{H}, J=9.1,2.6 \mathrm{~Hz}$, $\operatorname{ArH}), 7.39$ (d, $1 \mathrm{H}, J=2.7 \mathrm{~Hz}, \operatorname{ArH}), 4.02$ (s, 3H, $\left.\mathrm{OCH}_{3}\right), 3.51\left(\mathrm{tt}, 1 \mathrm{H}, J=11.4,3.4 \mathrm{~Hz},{ }^{c} \mathrm{C}_{6} \mathbf{H}_{11}\right), 2.09$ $1.86\left(\mathrm{~m}, 7 \mathrm{H},{ }^{c} \mathrm{C}_{6} \mathbf{H}_{11}\right), 1.64-1.53\left(\mathrm{~m}, 2 \mathrm{H},{ }^{c} \mathrm{C}_{6} \mathbf{H}_{11}\right), 1.46$ (qt, $\left.1 \mathrm{H}, J=12.5,3.1 \mathrm{~Hz},{ }^{c} \mathrm{C}_{6} \mathbf{H}_{11}\right)$.

${ }^{13} \mathrm{C} \mathrm{NMR}\left(125 \mathrm{MHz}, \mathrm{CDCl}_{3}, 20^{\circ} \mathrm{C}\right) \delta:$

FTIR (neat) $\mathrm{cm}^{-1}$ :

HRMS (ESI):

TLC (30\% EtOAc/hexanes), $R_{\mathrm{f}}$ :
$173.5,158.8,156.2,148.9,147.0,144.9,131.5,129.1$, $126.1,123.8,123.1,102.3,56.0,41.8,32.1,26.7,26.3$.

2929 (s), 2851 (m), $1621(\mathrm{w}), 1595$ (w), 1544 (m), 1512 (s), $1339(\mathrm{~s}), 1256$ (m), 1223 (m).

calcd for $\mathrm{C}_{21} \mathrm{H}_{21} \mathrm{~N}_{3} \mathrm{NaO}_{3}[\mathrm{M}+\mathrm{Na}]^{+}$: 386.1481 , found: 386.1459 .

0.58 (UV, CAM). 

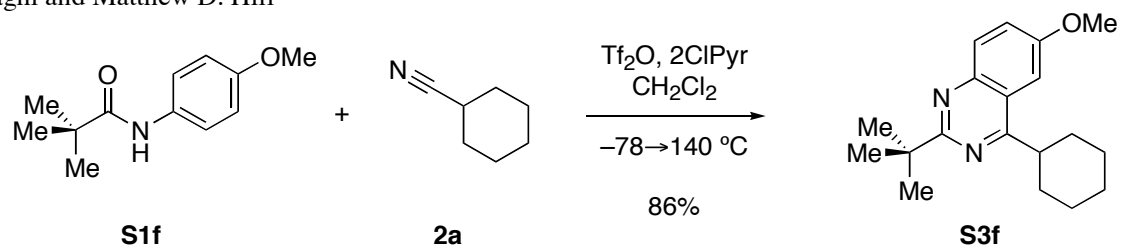

\section{2-tert-Butyl-4-cyclohexyl-6-methoxy-quinazoline (S3f, Table 2, entry 6):}

Trifluoromethanesulfonic anhydride $(88 \mu \mathrm{L}, 0.53 \mathrm{mmol}, 1.1$ equiv) was added via syringe over $1 \mathrm{~min}$ to a stirred mixture of amide $\mathbf{S 1 f}(100 \mathrm{mg}, 0.480 \mathrm{mmol}, 1$ equiv) and 2-chloropyridine (55 $\mu \mathrm{L}, 0.58 \mathrm{mmol}, 1.2$ equiv) in dichloromethane $(1.6 \mathrm{~mL})$ at $-78^{\circ} \mathrm{C}$. After $5 \mathrm{~min}$, the reaction mixture was placed in an ice-water bath and warmed to $0{ }^{\circ} \mathrm{C}$, the nitrile $2 \mathrm{a}(58 \mathrm{mg}, 0.53 \mathrm{mmol}, 1.1$ equiv) was added via syringe, and the resulting solution was allowed to warm to ambient temperature for 5 minutes before the reaction vessel was placed into a microwave reactor and heated to $140^{\circ} \mathrm{C}$. After $20 \mathrm{~min}$, the reaction vessel was removed from the microwave reactor and allowed to cool to ambient temperature before aqueous sodium hydroxide solution $(1 \mathrm{~mL}, 1 \mathrm{~N})$ was introduced to neutralize the trifluoromethanesulfonate salts. Dichloromethane $(5 \mathrm{~mL})$ was added to dilute the mixture and the layers were separated. The organic layer was washed with brine $(2 \mathrm{~mL})$, was dried over anhydrous sodium sulfate, and was filtered. The volatiles were removed under reduced pressure and the residue was purified by flash column chromatography (eluent: $5 \%$ EtOAc in hexanes; $\mathrm{SiO}_{2}: 15 \times 1.5 \mathrm{~cm}$ ) on neutralized silica gel to give the quinazoline product $\mathbf{S 3 f}$ as a pale yellow solid (124 $\mathrm{mg}, 86 \%)$.

${ }^{1} \mathrm{H}$ NMR $\left(500 \mathrm{MHz}, \mathrm{CDCl}_{3}, 20^{\circ} \mathrm{C}\right) \delta$ :

${ }^{13} \mathrm{C}$ NMR $\left(125 \mathrm{MHz}, \mathrm{CDCl}_{3}, 20{ }^{\circ} \mathrm{C}\right) \delta$ :

FTIR (neat) $\mathrm{cm}^{-1}$ :

HRMS (ESI):

TLC (20\% EtOAc/hexanes), $R_{\mathrm{f}}:$ $7.91(\mathrm{~d}, 1 \mathrm{H}, J=9.1 \mathrm{~Hz}, \operatorname{ArH}), 7.46(\mathrm{dd}, 1 \mathrm{H}, J=9.1,2.7$ $\mathrm{Hz}, \operatorname{ArH}), 7.32(\mathrm{~d}, 1 \mathrm{H}, J=2.7 \mathrm{~Hz}, \operatorname{ArH}), 3.97$ (s, 3H, $\left.\mathrm{OCH}_{3}\right), 3.40$ (tt, $\left.1 \mathrm{H}, J=11.4,3.2 \mathrm{~Hz},{ }^{c} \mathrm{C}_{6} \mathbf{H}_{11}\right), 1.98-$ $1.80\left(\mathrm{~m}, 7 \mathrm{H},{ }^{c} \mathrm{C}_{6} \mathbf{H}_{11}\right), 1.58-1.50\left(\mathrm{~m}, 2 \mathrm{H},{ }^{c} \mathrm{C}_{6} \mathbf{H}_{11}\right), 1.49$ (s, $\left.9 \mathrm{H}, \mathrm{C}\left(\mathrm{CH}_{3}\right)_{3}\right), 1.40$ (qt, $\left.1 \mathrm{H}, J=12.7,3.1 \mathrm{~Hz},{ }^{c} \mathrm{C}_{6} \mathbf{H}_{11}\right)$.

$172.2,170.9,157.5,146.5,130.9,124.6,121.6,102.1$, $55.8,41.5,39.6,32.0,29.9,26.7,26.4$.

2948 (w), 2912 (m), 2848 (m), $1619(\mathrm{w}), 1556(\mathrm{~m})$, $1497(\mathrm{~m}), 1221(\mathrm{~s})$.

calcd for $\mathrm{C}_{19} \mathrm{H}_{27} \mathrm{~N}_{2} \mathrm{O}[\mathrm{M}+\mathrm{H}]^{+}:$299.2123, found: 299.2121 .

$0.60(\mathrm{UV}, \mathrm{CAM})$ 

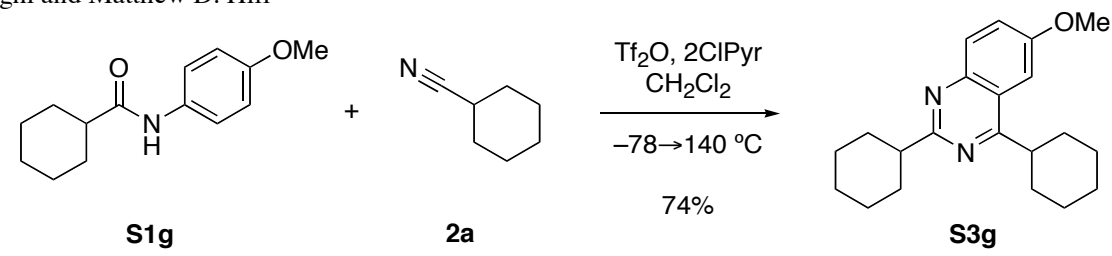

2,4-Dicyclohexyl-6-methoxy-quinazoline (S3g, Table 2, entry 7):

Trifluoromethanesulfonic anhydride $(90 \mu \mathrm{L}, 0.54 \mathrm{mmol}, 1.1$ equiv) was added via syringe over $1 \mathrm{~min}$ to a stirred mixture of amide $\mathbf{S 1 g}$ (115 mg, $0.493 \mathrm{mmol}, 1$ equiv) and 2-chloropyridine (56 $\mu \mathrm{L}, 0.59 \mathrm{mmol}, 1.2$ equiv) in dichloromethane $(1.6 \mathrm{~mL})$ at $-78^{\circ} \mathrm{C}$. After $5 \mathrm{~min}$, the reaction mixture was placed in an ice-water bath and warmed to $0{ }^{\circ} \mathrm{C}$, the nitrile $2 \mathrm{a}(59 \mathrm{mg}, 0.54 \mathrm{mmol}, 1.1$ equiv) was added via syringe, and the resulting solution was allowed to warm to ambient temperature for 5 minutes before the reaction vessel was placed into a microwave reactor and heated to $140{ }^{\circ} \mathrm{C}$. After $20 \mathrm{~min}$, the reaction vessel was removed from the microwave reactor and allowed to cool to ambient temperature before aqueous sodium hydroxide solution $(1 \mathrm{~mL}, 1 \mathrm{~N})$ was introduced to neutralize the trifluoromethanesulfonate salts. Dichloromethane $(5 \mathrm{~mL})$ was added to dilute the mixture and the layers were separated. The organic layer was washed with brine $(2 \mathrm{~mL})$, was dried over anhydrous sodium sulfate, and was filtered. The volatiles were removed under reduced pressure and the residue was purified by flash column chromatography (eluent: 5\% EtOAc in hexanes; $\mathrm{SiO}_{2}: 15 \times 1.5 \mathrm{~cm}$ ) on neutralized silica gel to give the quinazoline product $\mathbf{S 3 g}$ as a white solid (119 $\mathrm{mg}, 74 \%$ ).

${ }^{1} \mathrm{H}$ NMR $\left(500 \mathrm{MHz}, \mathrm{CDCl}_{3}, 20{ }^{\circ} \mathrm{C}\right) \delta: \quad 7.89(\mathrm{~d}, 1 \mathrm{H}, J=9.1 \mathrm{~Hz}, \mathrm{ArH}), 7.47(\mathrm{dd}, 1 \mathrm{H}, J=9.1,2.9$ $\mathrm{Hz}, \operatorname{ArH}), 7.32$ (d, 1H, J=2.9 Hz, ArH), 3.97 (s, 3H, $\left.\mathrm{OCH}_{3}\right), 3.44\left(\mathrm{tt}, 1 \mathrm{H}, J=11.5,3.2 \mathrm{~Hz},{ }^{c} \mathrm{C}_{6} \mathbf{H}_{11}\right), 2.95(\mathrm{tt}$, $\left.1 \mathrm{H}, J=11.7,3.5 \mathrm{~Hz},{ }^{c} \mathrm{C}_{6} \mathbf{H}_{11}\right), 2.08-1.72(\mathrm{~m}, 14 \mathrm{H}$, $\left.{ }^{c} \mathrm{C}_{6} \mathbf{H}_{11},{ }^{c} \mathrm{C}_{6} \mathbf{H}_{11}\right), 1.58-1.34\left(\mathrm{~m}, 6 \mathrm{H},{ }^{c} \mathrm{C}_{6} \mathbf{H}_{11},{ }^{c} \mathrm{C}_{6} \mathbf{H}_{11}\right)$.

${ }^{13} \mathrm{C}$ NMR $\left(125 \mathrm{MHz}, \mathrm{CDCl}_{3}, 20^{\circ} \mathrm{C}\right) \delta$ :

FTIR (neat) $\mathrm{cm}^{-1}$ :

HRMS (ESI):

TLC (20\% EtOAc/hexanes), $R_{\mathrm{f}}:$ :
$172.9,168.4,157.4,146.7,130.5,125.0,122.1,102.2$ $55.8,47.9,41.5,32.2,32.0,26.7,26.6,26.4,26.3$.

2927 (s), 2852 (m), 1623 (w), 1556 (m), 1449 (m), 1222 (s).

calcd for $\mathrm{C}_{21} \mathrm{H}_{29} \mathrm{~N}_{2} \mathrm{O}[\mathrm{M}+\mathrm{H}]^{+}$: 325.2280, found: 325.2274 .

0.56 (UV, CAM). 


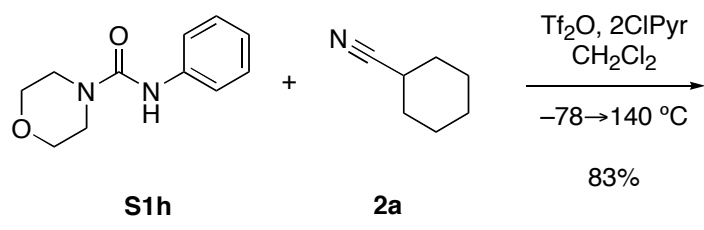

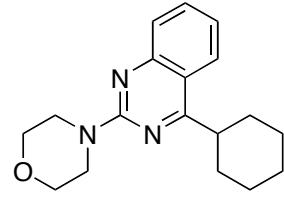

S3h

\section{4-Cyclohexyl-2-morpholin-4-yl-quinazoline (S3h, Table 2, entry 8):}

Trifluoromethanesulfonic anhydride $(97 \mu \mathrm{L}, 0.59 \mathrm{mmol}, 1.1$ equiv) was added via syringe over $1 \mathrm{~min}$ to a stirred mixture of amide $\mathbf{S 1 h}(110 \mathrm{mg}, 0.530 \mathrm{mmol}, 1$ equiv), nitrile $\mathbf{2 a}(64 \mathrm{mg}, 0.59$ mmol, 1.1 equiv) and 2-chloropyridine $(61 \mu \mathrm{L}, 0.64 \mathrm{mmol}, 1.2$ equiv) in dichloromethane $(1.8 \mathrm{~mL})$ at $-78^{\circ} \mathrm{C}$. After $5 \mathrm{~min}$, the reaction mixture was placed in an ice-water bath for 5 minutes and warmed to $0{ }^{\circ} \mathrm{C}$. The resulting solution was allowed to warm to ambient temperature for 5 minutes before the reaction vessel was placed into a microwave reactor and heated to $140{ }^{\circ} \mathrm{C}$. After $20 \mathrm{~min}$, the reaction vessel was removed from the microwave reactor and allowed to cool to ambient temperature before aqueous sodium hydroxide solution $(1 \mathrm{~mL}, 1 \mathrm{~N})$ was introduced to neutralize the trifluoromethanesulfonate salts. Dichloromethane $(5 \mathrm{~mL})$ was added to dilute the mixture and the layers were separated. The organic layer was washed with brine $(2 \mathrm{~mL})$, was dried over anhydrous sodium sulfate, and was filtered. The volatiles were removed under reduced pressure and the residue was purified by flash column chromatography (eluent: $10 \%$ EtOAc in hexanes; $\mathrm{SiO}_{2}: 15 \times 1.5 \mathrm{~cm}$ ) on neutralized silica gel to give the quinazoline product $\mathbf{S 3 h}$ as a white solid (131 $\mathrm{mg}, 83 \%)$.

${ }^{1} \mathrm{H}$ NMR $\left(500 \mathrm{MHz}, \mathrm{CDCl}_{3}, 20{ }^{\circ} \mathrm{C}\right) \delta$ :

${ }^{13} \mathrm{C}$ NMR $\left(125 \mathrm{MHz}, \mathrm{CDCl}_{3}, 20^{\circ} \mathrm{C}\right) \delta$ :

FTIR (neat) $\mathrm{cm}^{-1}$ :

HRMS (ESI):

TLC (20\% EtOAc/hexanes), $R_{\mathrm{f}}:$ : $7.92(\mathrm{~d}, 1 \mathrm{H}, J=8.3 \mathrm{~Hz}, \operatorname{ArH}), 7.65-7.58(\mathrm{~m}, 2 \mathrm{H}, \operatorname{ArH})$, 7.21 (ddd, 1H, $J=8.2,6.4,1.6 \mathrm{~Hz}, \operatorname{ArH}), 3.97$ (t, 4H, $J$ $\left.=4.7 \mathrm{~Hz}, \mathrm{OCH}_{2} \mathrm{CH}_{2} \mathrm{~N}\right), 3.83(\mathrm{t}, 4 \mathrm{H}, J=4.7 \mathrm{~Hz}$, $\left.\mathrm{OCH}_{2} \mathrm{CH}_{2} \mathrm{~N}\right), 3.41$ (tt, $\left.1 \mathrm{H}, J=11.4,2.9 \mathrm{~Hz},{ }^{c} \mathrm{C}_{6} \mathbf{H}_{11}\right)$, $1.98-1.69\left(\mathrm{~m}, 7 \mathrm{H},{ }^{c} \mathrm{C}_{6} \mathbf{H}_{11}\right), 1.51(\mathrm{tt}, 2 \mathrm{H}, J=9.6,4.2 \mathrm{~Hz}$, $\left.{ }^{c} \mathrm{C}_{6} \mathbf{H}_{11}\right) 1.35$ (tt, $\left.1 \mathrm{H}, J=12.8,3.4 \mathrm{~Hz},{ }^{c} \mathrm{C}_{6} \mathbf{H}_{11}\right)$.

$175.8,158.9,152.6,133.3,126.8,124.6,122.3,118.1$, $67.2,44.7,41.5,32.1,26.7,26.4$.

3064 (w), 2930 (s), 2852 (s), 1615 (s), 1579 (s), 1554 (s), $1486(\mathrm{~s}), 1227(\mathrm{~s})$.

calcd for $\mathrm{C}_{18} \mathrm{H}_{24} \mathrm{~N}_{3} \mathrm{O}[\mathrm{M}+\mathrm{H}]^{+}$: 298.1919, found: 298.1911.

0.48 (UV, CAM). 


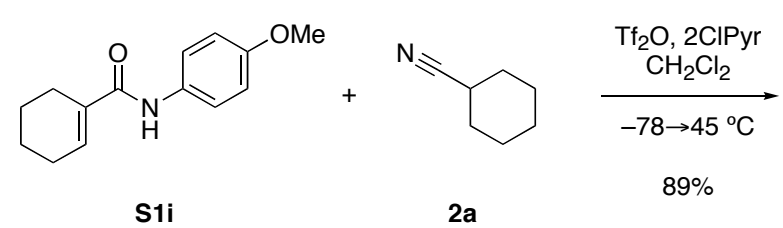

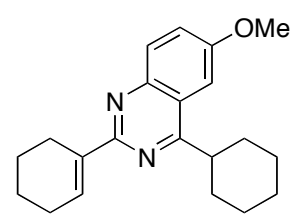

S3i

\section{2-Cyclohex-1-enyl-4-cyclohexyl-6-methoxy-quinazoline (S3i, Table 2, entry 9):}

Trifluoromethanesulfonic anhydride $(79 \mu \mathrm{L}, 0.48 \mathrm{mmol}, 1.1$ equiv) was added via syringe over $1 \mathrm{~min}$ to a stirred mixture of amide S1i (100 mg, $0.432 \mathrm{mmol}, 1$ equiv), 2-chloropyridine ( $49 \mu \mathrm{L}$, $0.53 \mathrm{mmol}, 1.2$ equiv), and nitrile $\mathbf{2 a}(236 \mathrm{mg}, 2.16 \mathrm{mmol}, 5.00$ equiv) in dichloromethane (1.4 mL) at $-78{ }^{\circ} \mathrm{C}$. After $5 \mathrm{~min}$, the reaction mixture was placed in an ice-water bath for 5 minutes and warmed to $0{ }^{\circ} \mathrm{C}$. The resulting solution was allowed to warm to ambient temperature for 5 minutes before the reaction vessel was placed into a preheated oil bath at $45{ }^{\circ} \mathrm{C}$ and maintained at that temperature. After $16 \mathrm{~h}$, the reaction mixture was allowed to cool to ambient temperature and aqueous sodium hydroxide solution $(1 \mathrm{~mL}, 1 \mathrm{~N})$ was introduced at to neutralize the trifluoromethanesulfonate salts. Dichloromethane $(5 \mathrm{~mL})$ was added to dilute the mixture and the layers were separated. The organic layer was washed with brine $(2 \mathrm{~mL})$, was dried over anhydrous sodium sulfate, and was filtered. The volatiles were removed under reduced pressure and the residue was purified by flash column chromatography (eluent: $10 \%$ EtOAc in hexanes; $\mathrm{SiO}_{2}: 15 \times 1.5 \mathrm{~cm}$ ) on neutralized silica gel to give the quinazoline product S3i as a white solid (124 mg, 89\%).

${ }^{1} \mathrm{H} \mathrm{NMR}\left(500 \mathrm{MHz}, \mathrm{CDCl}_{3}, 20{ }^{\circ} \mathrm{C}\right) \delta$ :

$7.90(\mathrm{~d}, 1 \mathrm{H}, J=9.1 \mathrm{~Hz}, \operatorname{ArH}), 7.47-7.44$ (m, 2H, ArH, $\left.\mathrm{C}=\mathrm{CHCH}_{2}\right), 7.32(\mathrm{~d}, 1 \mathrm{H}, J=2.7 \mathrm{~Hz}, \operatorname{ArH}), 3.97(\mathrm{~s}, 3 \mathrm{H}$, $\left.\mathrm{OCH}_{3}\right), 3.41$ (tt, $\left.1 \mathrm{H}, J=10.9,2.7 \mathrm{~Hz},{ }^{c} \mathrm{C}_{6} \mathbf{H}_{11}\right), 2.77-$ $2.72\left(\mathrm{~m}, 2 \mathrm{H},{ }^{c} \mathrm{C}_{6} \mathbf{H}_{9}\right), 2.39-2.34\left(\mathrm{~m}, 2 \mathrm{H},{ }^{c} \mathrm{C}_{6} \mathbf{H}_{9}\right), 2.02-$ $1.70\left(\mathrm{~m}, 11 \mathrm{H},{ }^{c} \mathrm{C}_{6} \mathbf{H}_{11},{ }^{c} \mathrm{C}_{6} \mathbf{H}_{9}\right), 1.60-1.49(\mathrm{~m}, 2 \mathrm{H}$, ${ }^{c} \mathrm{C}_{6} \mathbf{H}_{11}$ ), 1.41 (qt, $1 \mathrm{H}, J=12.7,3.4 \mathrm{~Hz},{ }^{c} \mathrm{C}_{6} \mathbf{H}_{11}$ ).

${ }^{13} \mathrm{C}$ NMR $\left(125 \mathrm{MHz}, \mathrm{CDCl}_{3}, 20^{\circ} \mathrm{C}\right) \delta$ :

FTIR (neat) $\mathrm{cm}^{-1}$ :

HRMS (ESI):

TLC (20\% EtOAc/hexanes), $R_{\mathrm{f}}$ :
$172.0,160.1,157.5,146.7,137.4,132.9,131.0,124.8$, $122.1,102.5,55.8,41.6,32.0,26.8,26.4,26.4,25.6$, $23.1,22.5$.

2929 (s), 2853 (m), 1621 (w), 1547 (s), 1496 (m), 1226

calcd for $\mathrm{C}_{21} \mathrm{H}_{27} \mathrm{~N}_{2} \mathrm{O}[\mathrm{M}+\mathrm{H}]^{+}$: 323.2123, found: 323.2126 .

0.67 (UV, CAM). 

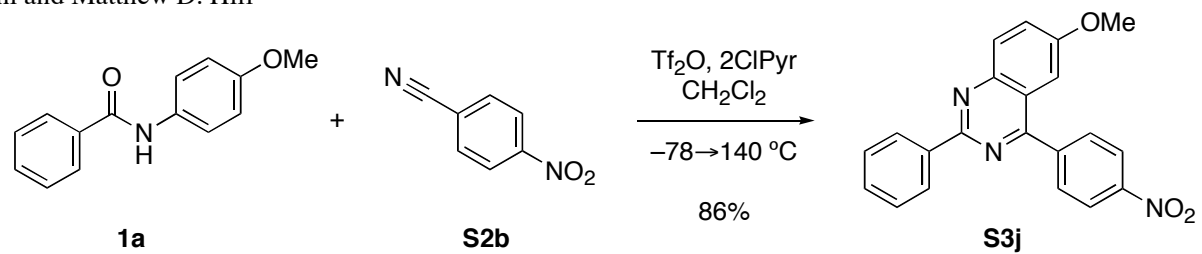

6-Methoxy-4-(4-nitro-phenyl)-2-phenyl-quinazoline (S3j, Table 2, entry 10):

Trifluoromethanesulfonic anhydride $(92 \mu \mathrm{L}, 0.56 \mathrm{mmol}, 1.1$ equiv) was added via syringe over $1 \mathrm{~min}$ to a stirred mixture of amide $\mathbf{1 a}(115 \mathrm{mg}, 0.506 \mathrm{mmol}, 1$ equiv), nitrile $\mathbf{S 2 b}$ ( $83 \mathrm{mg}, 0.56$ mmol, 1.1 equiv) and 2-chloropyridine $(58 \mu \mathrm{L}, 0.61 \mathrm{mmol}, 1.2$ equiv) in dichloromethane $(1.7 \mathrm{~mL})$ at $-78^{\circ} \mathrm{C}$. After $5 \mathrm{~min}$, the reaction mixture was placed in an ice-water bath for 5 minutes and warmed to $0{ }^{\circ} \mathrm{C}$. The resulting solution was allowed to warm to ambient temperature for 5 minutes before the reaction vessel was placed into a microwave reactor and heated to $140{ }^{\circ} \mathrm{C}$. After 20 min, the reaction vessel was removed from the microwave reactor and allowed to cool to ambient temperature before aqueous sodium hydroxide solution $(1 \mathrm{~mL}, 1 \mathrm{~N})$ was introduced to neutralize the trifluoromethanesulfonate salts. Dichloromethane $(5 \mathrm{~mL})$ was added to dilute the mixture and the layers were separated. The organic layer was washed with brine $(2 \mathrm{~mL})$, was dried over anhydrous sodium sulfate, and was filtered. The volatiles were removed under reduced pressure and the residue was purified by flash column chromatography (eluent: $20 \%$ EtOAc in hexanes; $\mathrm{SiO}_{2}: 15 \times 1.5 \mathrm{~cm}$ ) on neutralized silica gel to give the quinazoline product $\mathbf{S 3 j}$ as a pale yellow solid (156 $\mathrm{mg}, 86 \%$ ).

${ }^{1} \mathrm{H}$ NMR $\left(500 \mathrm{MHz}, \mathrm{CDCl}_{3}, 20{ }^{\circ} \mathrm{C}\right) \delta: \quad 8.66-8.62(\mathrm{~m}, 2 \mathrm{H}, \mathrm{ArH}), 8.51-8.47(\mathrm{~m}, 2 \mathrm{H}, \mathrm{ArH}), 8.13$ $(\mathrm{d}, 1 \mathrm{H}, J=9.3 \mathrm{~Hz}, \operatorname{ArH}), 8.11-8.07$ (m, 2H, ArH), 7.64 (dd, $1 \mathrm{H}, J=9.3,2.7 \mathrm{~Hz}, \operatorname{ArH}), 7.57-7.50(\mathrm{~m}, 3 \mathrm{H}, \mathrm{ArH})$, 7.24 (d, 1H, $J=2.7 \mathrm{~Hz}, \operatorname{ArH}), 3.89$ (s, 3H, OCH ${ }_{3}$.

${ }^{13} \mathrm{C}$ NMR $\left(125 \mathrm{MHz}, \mathrm{CDCl}_{3}, 20^{\circ} \mathrm{C}\right) \delta:$

FTIR (neat) $\mathrm{cm}^{-1}$ :

HRMS (ESI):

TLC (20\% EtOAc/hexanes), $R_{\mathrm{f}}$ :
$164.2,158.8,158.7,148.8,148.6,144.4,138.0,131.3$, $131.0,130.6,128.8,128.4,127.1,124.1,122.3,103.3$, 55.9 .

$3056(\mathrm{w}), 2971(\mathrm{w}), 1996(\mathrm{w}), 1621(\mathrm{~m}), 1543(\mathrm{~s}), 1513$ (s), 1350 (s), $1222(\mathrm{~m})$.

calcd for $\mathrm{C}_{21} \mathrm{H}_{16} \mathrm{~N}_{3} \mathrm{O}_{3}[\mathrm{M}+\mathrm{H}]^{+}$: 358.1192, found: 358.1183 .

0.36 (UV, CAM). 


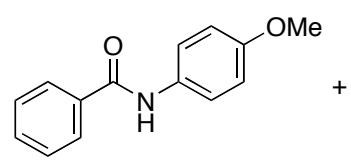

$1 a$

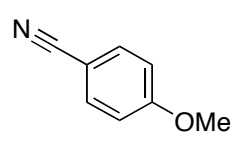

S2c

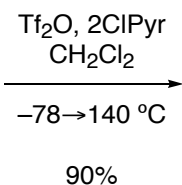

$90 \%$

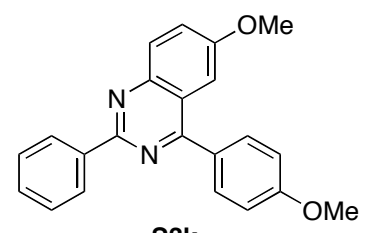

S3k

6-Methoxy-4-(4-methoxy-phenyl)-2-phenyl-quinazoline (S3k, Table 2, entry 11):

Trifluoromethanesulfonic anhydride $(92 \mu \mathrm{L}, 0.56 \mathrm{mmol}, 1.1$ equiv) was added via syringe over $1 \mathrm{~min}$ to a stirred mixture of amide $\mathbf{1 a}(115 \mathrm{mg}, 0.506 \mathrm{mmol}, 1$ equiv), nitrile $\mathbf{S 2 c}$ (74 $\mathrm{mg}, 0.56$ mmol, 1.1 equiv) and 2-chloropyridine $(58 \mu \mathrm{L}, 0.61 \mathrm{mmol}, 1.2$ equiv) in dichloromethane $(1.7 \mathrm{~mL})$ at $-78^{\circ} \mathrm{C}$. After $5 \mathrm{~min}$, the reaction mixture was placed in an ice-water bath for 5 minutes and warmed to $0{ }^{\circ} \mathrm{C}$. The resulting solution was allowed to warm to ambient temperature for 5 minutes before the reaction vessel was placed into a microwave reactor and heated to $140{ }^{\circ} \mathrm{C}$. After $20 \mathrm{~min}$, the reaction vessel was removed from the microwave reactor and allowed to cool to ambient temperature before aqueous sodium hydroxide solution $(1 \mathrm{~mL}, 1 \mathrm{~N})$ was introduced to neutralize the trifluoromethanesulfonate salts. Dichloromethane $(5 \mathrm{~mL})$ was added to dilute the mixture and the layers were separated. The organic layer was washed with brine $(2 \mathrm{~mL})$, was dried over anhydrous sodium sulfate, and was filtered. The volatiles were removed under reduced pressure and the residue was purified by flash column chromatography (eluent: $20 \%$ EtOAc in hexanes; $\mathrm{SiO}_{2}: 15 \times 1.5 \mathrm{~cm}$ ) on neutralized silica gel to give the quinazoline product S3K as a pale yellow solid (156 mg, 90\%).

${ }^{1} \mathrm{H}$ NMR $\left(500 \mathrm{MHz}, \mathrm{CDCl}_{3}, 20{ }^{\circ} \mathrm{C}\right) \delta: \quad 8.67-8.64(\mathrm{~m}, 2 \mathrm{H}, \mathrm{ArH}), 8.07(\mathrm{~d}, 1 \mathrm{H}, J=9.1 \mathrm{~Hz}, \mathrm{ArH})$, 7.94-7.90 (m, 2H, ArH), 7.57-7.45 (m, 5H, ArH), 7.16$7.12(\mathrm{~m}, 2 \mathrm{H}, \mathrm{ArH}), 3.95\left(\mathrm{~s}, 3 \mathrm{H}, \mathrm{OCH}_{3}\right), 3.89$ (s, 3H, $\left.\mathrm{OCH}_{3}\right)$.

${ }^{13} \mathrm{C}$ NMR $\left(125 \mathrm{MHz}, \mathrm{CDCl}_{3}, 20{ }^{\circ} \mathrm{C}\right) \delta: \quad 166.1,161.1,158.7,158.1,148.3,138.6,131.6,130.7$, $130.6,130.2,128.6,128.4,126.1,122.5,114.2,104.6$, 55.7, 55.6.

FTIR (neat) $\mathrm{cm}^{-1}$ :

$3006(\mathrm{w}), 2957(\mathrm{~m}), 2839(\mathrm{w}), 1608$ (s), $1564(\mathrm{~m}), 1534$

(s), 1499 (s), 1404 (s), 1259 (s), 1221 (m).

HRMS (ESI):

calcd for $\mathrm{C}_{22} \mathrm{H}_{19} \mathrm{~N}_{2} \mathrm{O}_{2}[\mathrm{M}+\mathrm{H}]^{+}$: 343.1447 , found: 343.1437.

TLC (20\% EtOAc/hexanes), $R_{\mathrm{f}}: \quad 0.33$ (UV, CAM). 


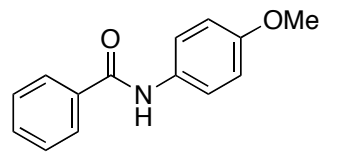

1a

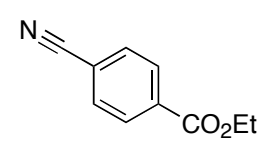

S2d

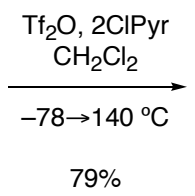

$79 \%$

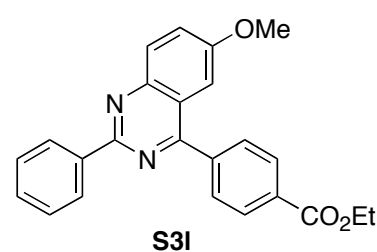

S3I

\section{4-(6-Methoxy-2-phenyl-quinazolin-4-yl)-benzoic acid ethyl ester (S3I, Table 2, entry 12):}

Trifluoromethanesulfonic anhydride $(92 \mu \mathrm{L}, 0.56 \mathrm{mmol}, 1.1$ equiv) was added via syringe over $1 \mathrm{~min}$ to a stirred mixture of amide $\mathbf{1 a}(115 \mathrm{mg}, 0.506 \mathrm{mmol}, 1$ equiv), nitrile $\mathbf{S 2 d}$ (98 $\mathrm{mg}, 0.56$ mmol, 1.1 equiv) and 2-chloropyridine $(58 \mu \mathrm{L}, 0.61 \mathrm{mmol}, 1.2$ equiv) in dichloromethane $(1.7 \mathrm{~mL})$ at $-78^{\circ} \mathrm{C}$. After $5 \mathrm{~min}$, the reaction mixture was placed in an ice-water bath for 5 minutes and warmed to $0{ }^{\circ} \mathrm{C}$. The resulting solution was allowed to warm to ambient temperature for 5 minutes before the reaction vessel was placed into a microwave reactor and heated to $140{ }^{\circ} \mathrm{C}$. After $20 \mathrm{~min}$, the reaction vessel was removed from the microwave reactor and allowed to cool to ambient temperature before aqueous sodium hydroxide solution $(1 \mathrm{~mL}, 1 \mathrm{~N})$ was introduced to neutralize the trifluoromethanesulfonate salts. Dichloromethane $(5 \mathrm{~mL})$ was added to dilute the mixture and the layers were separated. The organic layer was washed with brine $(2 \mathrm{~mL})$, was dried over anhydrous sodium sulfate, and was filtered. The volatiles were removed under reduced pressure and the residue was purified by flash column chromatography (eluent: $10 \%$ EtOAc in hexanes; $\mathrm{SiO}_{2}: 15 \times 1.5 \mathrm{~cm}$ ) on neutralized silica gel to give the quinazoline product $\mathbf{S 3 I}$ as a white solid (154 $\mathrm{mg}, 79 \%$ ).

${ }^{1} \mathrm{H}$ NMR $\left(500 \mathrm{MHz}, \mathrm{CDCl}_{3}, 20{ }^{\circ} \mathrm{C}\right) \delta: \quad 8.67-8.63(\mathrm{~m}, 2 \mathrm{H}, \mathrm{ArH}), 8.30(\mathrm{~d}, 2 \mathrm{H}, J=8.0 \mathrm{~Hz}, \mathrm{ArH})$, $8.10(\mathrm{~d}, 1 \mathrm{H}, J=9.1 \mathrm{~Hz}, \operatorname{ArH}), 7.98(\mathrm{~d}, 2 \mathrm{H}, J=7.9 \mathrm{~Hz}$, ArH), $7.58(\mathrm{dd}, 1 \mathrm{H}, J=9.1,2.7 \mathrm{~Hz}, \operatorname{ArH}), 7.56-7.48(\mathrm{~m}$, $3 \mathrm{H}, \operatorname{ArH}), 7.31$ (d, $1 \mathrm{H}, J=2.7 \mathrm{~Hz}, \operatorname{ArH}), 4.48$ (q, 2H, $J$ $\left.=7.2 \mathrm{~Hz}, \mathrm{CO}_{2} \mathrm{CH}_{2} \mathrm{CH}_{3}\right), 3.87\left(\mathrm{~s}, 3 \mathrm{H}, \mathrm{OCH}_{3}\right), 1.48(\mathrm{t}, 3 \mathrm{H}$, $J=7.2 \mathrm{~Hz}, \mathrm{CO}_{2} \mathrm{CH}_{2} \mathrm{CH}_{3}$ ).

${ }^{13} \mathrm{C} \mathrm{NMR}\left(125 \mathrm{MHz}, \mathrm{CDCl}_{3}, 20^{\circ} \mathrm{C}\right) \delta:$

FTIR (neat) $\mathrm{cm}^{-1}$ :

HRMS (ESI):

TLC (20\% EtOAc/hexanes), $R_{\mathrm{f}}$ :
$166.4,165.7,158.9,158.4,148.5,142.4,138.3,131.7$, $131.0,130.4,130.0,130.0,128.8,128.5,126.8,122.5$, $103.9,61.5,55.8,14.6$.

2961 (w), 1717 (s), 1621 (w), 1536 (m), 1407 (m), 1271

(s), $1222(\mathrm{~s})$.

calcd for $\mathrm{C}_{24} \mathrm{H}_{21} \mathrm{~N}_{2} \mathrm{O}_{3}[\mathrm{M}+\mathrm{H}]^{+}$: 385.1552 ,

found: 385.1544 .

0.39 (UV, CAM). 


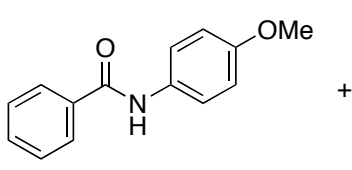

1a

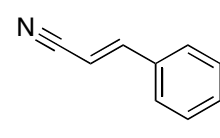

S2e

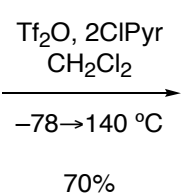

$70 \%$

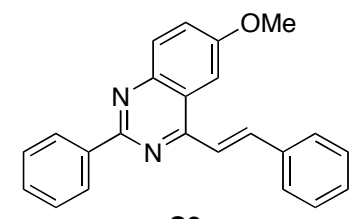

S3m

6-Methoxy-2-phenyl-4-styryl-quinazoline (S3m, Table 2, entry 13):

Trifluoromethanesulfonic anhydride $(92 \mu \mathrm{L}, 0.56 \mathrm{mmol}, 1.1$ equiv) was added via syringe over $1 \mathrm{~min}$ to a stirred mixture of amide $1 \mathrm{a}(115 \mathrm{mg}, 0.506 \mathrm{mmol}, 1$ equiv), nitrile $\mathbf{S 2 e}$ (72 $\mathrm{mg}, 0.56$ mmol, 1.1 equiv) and 2-chloropyridine $(58 \mu \mathrm{L}, 0.61 \mathrm{mmol}, 1.2$ equiv) in dichloromethane $(1.7 \mathrm{~mL})$ at $-78^{\circ} \mathrm{C}$. After $5 \mathrm{~min}$, the reaction mixture was placed in an ice-water bath for 5 minutes and warmed to $0{ }^{\circ} \mathrm{C}$. The resulting solution was allowed to warm to ambient temperature for 5 minutes before the reaction vessel was placed into a microwave reactor and heated to $140{ }^{\circ} \mathrm{C}$. After 20 min, the reaction vessel was removed from the microwave reactor and allowed to cool to ambient temperature before aqueous sodium hydroxide solution $(1 \mathrm{~mL}, 1 \mathrm{~N})$ was introduced to neutralize the trifluoromethanesulfonate salts. Dichloromethane $(5 \mathrm{~mL})$ was added to dilute the mixture and the layers were separated. The organic layer was washed with brine $(2 \mathrm{~mL})$, was dried over anhydrous sodium sulfate, and was filtered. The volatiles were removed under reduced pressure and the residue was purified by flash column chromatography (eluent: $20 \%$ EtOAc in hexanes; $\mathrm{SiO}_{2}: 15 \times 1.5 \mathrm{~cm}$ ) on neutralized silica gel to give the quinazoline product $\mathbf{S 3 m}$ as a white solid (120 $\mathrm{mg}, 70 \%)$.

${ }^{1} \mathrm{H}$ NMR $\left(500 \mathrm{MHz}, \mathrm{CDCl}_{3}, 20^{\circ} \mathrm{C}\right) \delta: \quad 8.71-8.68(\mathrm{~m}, 2 \mathrm{H}, \mathrm{ArH}), 8.45(\mathrm{~d}, 1 \mathrm{H}, J=15.4 \mathrm{~Hz}$ $\mathrm{CH}=\mathrm{CH}), 8.03(\mathrm{~d}, 1 \mathrm{H}, J=9.1 \mathrm{~Hz}, \operatorname{ArH}), 7.89(\mathrm{~d}, 1 \mathrm{H}, J$ $=15.4 \mathrm{~Hz}, \operatorname{ArH}), 7.80$ (d, 2H, J=7.4 Hz, ArH), 7.597.55 (m, 3H, ArH), 7.54-7.47 (m, 4H, ArH), 7.45-7.41 $(\mathrm{m}, 1 \mathrm{H}, \mathrm{ArH}), 4.04\left(\mathrm{~s}, 3 \mathrm{H}, \mathrm{OCH}_{3}\right)$.

${ }^{13} \mathrm{C}$ NMR $\left(125 \mathrm{MHz}, \mathrm{CDCl}_{3}, 20^{\circ} \mathrm{C}\right) \delta:$

FTIR (neat) $\mathrm{cm}^{-1}$ :

HRMS (ESI):

TLC (20\% EtOAc/hexanes), $R_{\mathrm{f}}$ :
$160.3,158.5,158.1,148.4,139.1,138.8,136.4,131.0$, $130.2,129.7,129.1,128.7,128.4,128.2,126.3,122.5$, 121.3, 101.6, 55.9 .

3059 (w), 2936 (w), 1621 (m), 1560 (m), 1533 (s), 1499 (m), 1408 (s), 1224 (s).

calcd for $\mathrm{C}_{23} \mathrm{H}_{19} \mathrm{~N}_{2} \mathrm{O}[\mathrm{M}+\mathrm{H}]^{+}$: 339.1497, found: 339.1492 .

0.38 (UV, CAM). 

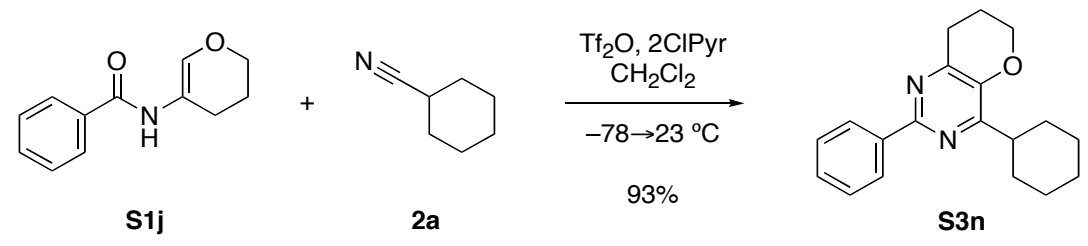

\section{4-Cyclohexyl-2-phenyl-7,8-dihydro-6H-pyrano[3,2-d]pyrimidine (S3n, Table 2, entry 14):}

Trifluoromethanesulfonic anhydride $(63 \mu \mathrm{L}, 0.38 \mathrm{mmol}, 1.1$ equiv) was added via syringe over $1 \mathrm{~min}$ to a stirred mixture of amide $\mathbf{S 1 j}$ ( $70 \mathrm{mg}, 0.34 \mathrm{mmol}, 1$ equiv), nitrile $\mathbf{2 a}$ (41 $\mathrm{mg}, 0.38$ mmol, 1.1 equiv) and 2-chloropyridine $(39 \mu \mathrm{L}, 0.41 \mathrm{mmol}, 1.2$ equiv) in dichloromethane $(1.0 \mathrm{~mL})$ at $-78^{\circ} \mathrm{C}$. After $5 \mathrm{~min}$, the reaction mixture was placed in an ice-water bath for 5 minutes and warmed to $0{ }^{\circ} \mathrm{C}$. The resulting solution was allowed to warm to ambient temperature. After $1 \mathrm{~h}$, aqueous sodium hydroxide solution $(1 \mathrm{~mL}, 1 \mathrm{~N})$ was introduced to neutralize the trifluoromethanesulfonate salts. Dichloromethane $(5 \mathrm{~mL})$ was added to dilute the mixture and the layers were separated. The organic layer was washed with brine $(2 \mathrm{~mL})$, was dried over anhydrous sodium sulfate, and was filtered. The volatiles were removed under reduced pressure and the residue was purified by flash column chromatography (eluent: $10 \%$ EtOAc in hexanes; $\mathrm{SiO}_{2}: 15 \times 1.5 \mathrm{~cm}$ ) on neutralized silica gel to give the pyrimidine product $\mathbf{S 3 n}$ as a white solid (94 $\mathrm{mg}, 93 \%$ ).

${ }^{1} \mathrm{H}$ NMR $\left(500 \mathrm{MHz}, \mathrm{CDCl}_{3}, 20^{\circ} \mathrm{C}\right) \delta: \quad 8.40-8.36(\mathrm{~m}, 2 \mathrm{H}, \operatorname{ArH}), 7.47-7.38(\mathrm{~m}, 3 \mathrm{H}, \operatorname{ArH}), 4.27$ (t, $\left.2 \mathrm{H}, J=5.1 \mathrm{~Hz}, \mathrm{CH}_{2} \mathrm{CH}_{2} \mathrm{CH}_{2} \mathrm{O}\right), 3.06$ (tt, $1 \mathrm{H}, J=11.9$, $\left.3.5 \mathrm{~Hz},{ }^{c} \mathrm{C}_{6} \mathbf{H}_{11}\right), 2.98$ (t, $\left.2 \mathrm{H}, J=6.6 \mathrm{~Hz}, \mathrm{CH}_{2} \mathrm{CH}_{2} \mathrm{CH}_{2} \mathrm{O}\right)$, 2.18-2.13 (m, 2H, $\left.\mathrm{CH}_{2} \mathrm{CH}_{2} \mathrm{CH}_{2} \mathrm{O}\right), 1.91-1.69(\mathrm{~m}, 7 \mathrm{H}$, ${ }^{c} \mathrm{C}_{6} \mathbf{H}_{11}$ ), 1.44 (qt, $2 \mathrm{H}, J=12.7,3.2 \mathrm{~Hz},{ }^{c} \mathrm{C}_{6} \mathbf{H}_{11}$ ), 1.35 (qt, $\left.1 \mathrm{H}, J=12.7,3.2 \mathrm{~Hz},{ }^{C} \mathrm{C}_{6} \mathbf{H}_{11}\right)$.

${ }^{13} \mathrm{C}$ NMR $\left(125 \mathrm{MHz}, \mathrm{CDCl}_{3}, 20^{\circ} \mathrm{C}\right) \delta:$

FTIR (neat) $\mathrm{cm}^{-1}$ :

HRMS (ESI):

TLC (20\% EtOAc/hexanes), $R_{\mathrm{f}}$ :
$161.7,155.8,149.6,146.0,138.7,129.3,128.5,127.7$, $66.7,38.8,30.8,28.1,26.6,26.3,22.2$.

$3065(\mathrm{w}), 2930(\mathrm{~s}), 2852(\mathrm{~m}), 1587(\mathrm{w}), 1565(\mathrm{~s}), 1430$

(s), $1410(\mathrm{~s}), 1208(\mathrm{~m})$.

calcd for $\mathrm{C}_{19} \mathrm{H}_{23} \mathrm{~N}_{2} \mathrm{O}[\mathrm{M}+\mathrm{H}]^{+}:$295.1810,

found: 295.1796.

0.52 (UV, CAM). 


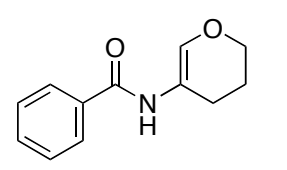

S1j

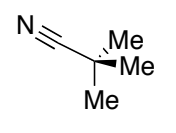

S2f

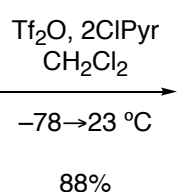

$88 \%$

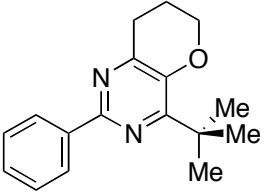

S30

\section{4-tert-Butyl-2-phenyl-7,8-dihydro-6H-pyrano[3,2-d]pyrimidine (S30, Table 2, entry 15):}

Trifluoromethanesulfonic anhydride $(890 \mu \mathrm{L}, 5.41 \mathrm{mmol}, 1.1$ equiv) was added via syringe over $3 \mathrm{~min}$ to a stirred mixture of amide $\mathbf{S 1 j}$ (1.0 g, $4.9 \mathrm{mmol}, 1$ equiv), nitrile S2f (450 $\mathrm{mg}, 5.41$ mmol, 1.1 equiv) and 2-chloropyridine $(560 \mu \mathrm{L}, 5.90 \mathrm{mmol}, 1.2$ equiv) in dichloromethane $(16 \mathrm{~mL})$ at $-78{ }^{\circ} \mathrm{C}$. After $5 \mathrm{~min}$, the reaction mixture was placed in an ice-water bath for 5 minutes and warmed to $0{ }^{\circ} \mathrm{C}$. The resulting solution was allowed to warm to ambient temperature. After $3 \mathrm{~h}$, aqueous sodium hydroxide solution $(5 \mathrm{~mL}, 1 \mathrm{~N})$ was introduced to neutralize the trifluoromethanesulfonate salts. Dichloromethane $(50 \mathrm{~mL})$ was added to dilute the mixture and the layers were separated. The aqueous layer was extracted with dichloromethane $(2 \times 50 \mathrm{~mL})$ and the organic fractions were combined, dried over anhydrous sodium sulfate, and were filtered. The volatiles were removed under reduced pressure and the residue was purified by flash column chromatography (eluent: 10\% EtOAc in hexanes; $\mathrm{SiO}_{2}: 12 \times 3 \mathrm{~cm}$ ) on neutralized silica gel to give the pyrimidine product $\mathbf{S 3 0}$ as a white solid (1.17 g, 88\%).

${ }^{1} \mathrm{H}$ NMR $\left(500 \mathrm{MHz}, \mathrm{CDCl}_{3}, 20{ }^{\circ} \mathrm{C}\right) \delta:$

${ }^{13} \mathrm{C}$ NMR $\left(125 \mathrm{MHz}, \mathrm{CDCl}_{3}, 20^{\circ} \mathrm{C}\right) \delta:$

FTIR (neat) $\mathrm{cm}^{-1}$ :

HRMS (ESI):

TLC (20\% EtOAc/hexanes), $R_{\mathrm{f}}$ :
8.42-8.37 (m, 2H, ArH), 7.48-7.38 (m, 3H, ArH), 4.27 (t, $\left.2 \mathrm{H}, J=5.1 \mathrm{~Hz}, \mathrm{CH}_{2} \mathrm{CH}_{2} \mathrm{CH}_{2} \mathrm{O}\right), 2.98(\mathrm{t}, 2 \mathrm{H}, J=6.7$ $\left.\mathrm{Hz}, \mathrm{CH}_{2} \mathrm{CH}_{2} \mathrm{CH}_{2} \mathrm{O}\right), 2.20-2.14\left(\mathrm{~m}, 2 \mathrm{H}, \mathrm{CH}_{2} \mathrm{CH}_{2} \mathrm{CH}_{2} \mathrm{O}\right)$, $1.46\left(\mathrm{~s}, 9 \mathrm{H}, \mathrm{C}\left(\mathrm{CH}_{3}\right)_{3}\right)$.

$163.3,154.8,150.4,147.6,138.6,129.4,128.5,127.7$, $66.3,38.2,28.3,28.1,22.1$.

$3065(\mathrm{w}), 2955(\mathrm{~m}), 2868(\mathrm{w}), 1558(\mathrm{~m}), 1429(\mathrm{~m})$, $1406(\mathrm{~s}), 1366(\mathrm{~m}), 1353(\mathrm{~m})$.

calcd for $\mathrm{C}_{17} \mathrm{H}_{21} \mathrm{~N}_{2} \mathrm{O}[\mathrm{M}+\mathrm{H}]^{+}$: 269.1654, found: 269.1653.

0.67 (UV, CAM). 


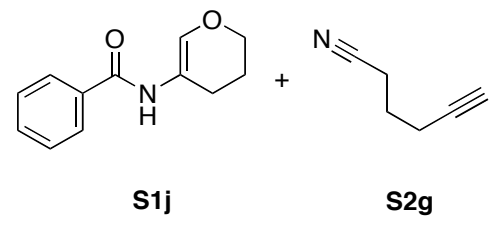

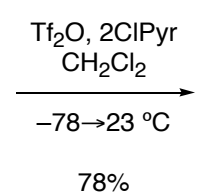

$78 \%$

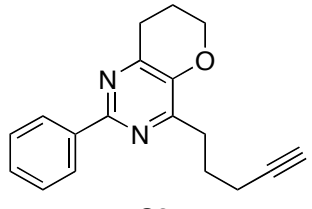

S3p

\section{4-Pent-4-ynyl-2-phenyl-7,8-dihydro-6H-pyrano[3,2- $d]$ pyrimidine (S3p, Table 2, entry 16):}

Trifluoromethanesulfonic anhydride $(89 \mu \mathrm{L}, 0.54 \mathrm{mmol}, 1.1$ equiv) was added via syringe over $1 \mathrm{~min}$ to a stirred mixture of amide $\mathbf{S 1 j}$ (100 $\mathrm{mg}, 0.490 \mathrm{mmol}, 1$ equiv), nitrile $\mathbf{S 2 g}$ (50 $\mathrm{mg}, 0.54$ mmol, 1.1 equiv) and 2-chloropyridine $(56 \mu \mathrm{L}, 0.59 \mathrm{mmol}, 1.2$ equiv) in dichloromethane $(1.6 \mathrm{~mL})$ at $-78^{\circ} \mathrm{C}$. After $5 \mathrm{~min}$, the reaction mixture was placed in an ice-water bath for 5 minutes and warmed to $0{ }^{\circ} \mathrm{C}$. The resulting solution was allowed to warm to ambient temperature. After $1 \mathrm{~h}$, aqueous sodium hydroxide solution $(1 \mathrm{~mL}, 1 \mathrm{~N})$ was introduced to neutralize the trifluoromethanesulfonate salts. Dichloromethane $(5 \mathrm{~mL})$ was added to dilute the mixture and the layers were separated. The organic layer was washed with brine $(2 \mathrm{~mL})$, was dried over anhydrous sodium sulfate, and was filtered. The volatiles were removed under reduced pressure and the residue was purified by flash column chromatography (eluent: 10\% EtOAc in hexanes; $\mathrm{SiO}_{2}: 15 \times 1.5 \mathrm{~cm}$ ) on neutralized silica gel to give the pyrimidine product $\mathbf{S 3 p}$ as a colorless oil (107 $\mathrm{mg}, 78 \%$ ).

${ }^{1} \mathrm{H}$ NMR $\left(500 \mathrm{MHz}, \mathrm{CDCl}_{3}, 20^{\circ} \mathrm{C}\right) \delta: \quad 8.36-8.33(\mathrm{~m}, 2 \mathrm{H}, \mathrm{ArH}), 7.48-7.38(\mathrm{~m}, 3 \mathrm{H}, \operatorname{ArH}), 4.28$ (t, $\left.2 \mathrm{H}, J=5.1 \mathrm{~Hz}, \mathrm{CH}_{2} \mathrm{CH}_{2} \mathrm{CH}_{2} \mathrm{O}\right), 2.98(\mathrm{t}, 2 \mathrm{H}, J=6.6$ $\left.\mathrm{Hz}, \mathrm{CH}_{2} \mathrm{CH}_{2} \mathrm{CH}_{2} \mathrm{O}\right), 2.92(\mathrm{t}, 2 \mathrm{H}, J=7.2 \mathrm{~Hz}$, $\left.\mathrm{CH}_{2} \mathrm{CH}_{2} \mathrm{CH}_{2} \mathrm{CCH}\right), 2.37 \mathrm{td}, 2 \mathrm{H}, J=7.1,2.6 \mathrm{~Hz}$, $\left.\mathrm{CH}_{2} \mathrm{CH}_{2} \mathrm{CH}_{2} \mathrm{CCH}\right), 2.20-2.14\left(\mathrm{~m}, 2 \mathrm{H}, \mathrm{CH}_{2} \mathrm{CH}_{2} \mathrm{CH}_{2} \mathrm{O}\right)$, 2.08 (quint, $2 \mathrm{H}, J=7.4 \mathrm{~Hz}, \mathrm{CH}_{2} \mathrm{CH}_{2} \mathrm{CH}_{2} \mathrm{CCH}$ ), 2.01 $\left(1 \mathrm{H}, \mathrm{t}, J=2.7 \mathrm{~Hz}, \mathrm{CH}_{2} \mathrm{CH}_{2} \mathrm{CH}_{2} \mathrm{CCH}\right)$.

${ }^{13} \mathrm{C} \mathrm{NMR}\left(125 \mathrm{MHz}, \mathrm{CDCl}_{3}, 20{ }^{\circ} \mathrm{C}\right) \delta:$

FTIR (neat) $\mathrm{cm}^{-1}$ :

HRMS (ESI):

TLC (20\% EtOAc/hexanes), $R_{\mathrm{f}}$ :
$157.2,155.9,149.7,146.9,138.4,129.5,128.6,127.7$, $84.5,68.8,66.9,30.4,28.1,26.0,22.2,18.5$.

3297 (s), 3066 (m), 2939 (s), 2117 (w), 1587 (s), 1569 (s), 1411 (s), $1202(\mathrm{~m})$.

calcd for $\mathrm{C}_{18} \mathrm{H}_{19} \mathrm{~N}_{2} \mathrm{O}[\mathrm{M}+\mathrm{H}]^{+}: 279.1497$, found: 279.1496.

$0.41(\mathrm{UV}, \mathrm{CAM})$. 


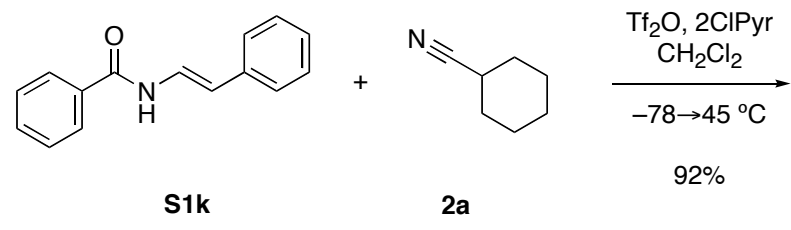

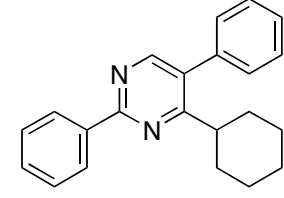

S3q

\section{4-Cyclohexyl-2,5-diphenyl-pyrimidine (S3q, Table 2, entry 17):}

Trifluoromethanesulfonic anhydride $(90 \mu \mathrm{L}, 0.54 \mathrm{mmol}, 1.1$ equiv) was added via syringe over $1 \mathrm{~min}$ to a stirred mixture of amide $\mathbf{S 1 k}(110 \mathrm{mg}, 0.493 \mathrm{mmol}, 1$ equiv), nitrile $\mathbf{2 a}$ (269 mg, 2.47 mmol, 5.00 equiv) and 2-chloropyridine $(56 \mu \mathrm{L}, 0.59 \mathrm{mmol}, 1.2$ equiv) in dichloromethane $(1.7 \mathrm{~mL})$ at $-78^{\circ} \mathrm{C}$. After $5 \mathrm{~min}$, the reaction mixture was placed in an ice-water bath and warmed to $0{ }^{\circ} \mathrm{C}$, and the resulting solution was allowed to warm to ambient temperature for 5 minutes before the reaction vessel was placed into a preheated oil bath at $45^{\circ} \mathrm{C}$ and maintained at that temperature. After $1 \mathrm{~h}$, the reaction vessel was allowed to cool to ambient temperature and aqueous sodium hydroxide solution $(1 \mathrm{~mL}, 1 \mathrm{~N})$ was introduced to neutralize the trifluoromethanesulfonate salts. Dichloromethane $(5 \mathrm{~mL})$ was added to dilute the mixture and the layers were separated. The organic layer was washed with brine $(2 \mathrm{~mL})$, was dried over anhydrous sodium sulfate, and was filtered. The volatiles were removed under reduced pressure, and the residue was purified by flash column chromatography (eluent: $5 \%$ EtOAc in hexanes; $\mathrm{SiO}_{2}: 15 \times 1.5 \mathrm{~cm}$ ) on neutralized silica gel to give the pyrimidine product $\mathbf{S 3 q}$ as a white solid (142 mg, 92\%).

${ }^{1} \mathrm{H}$ NMR $\left(500 \mathrm{MHz}, \mathrm{CDCl}_{3}, 20^{\circ} \mathrm{C}\right) \delta:$

${ }^{13} \mathrm{C}$ NMR $\left(125 \mathrm{MHz}, \mathrm{CDCl}_{3}, 20^{\circ} \mathrm{C}\right) \delta$ :

FTIR (neat) $\mathrm{cm}^{-1}$ :

HRMS (ESI):

TLC (20\% EtOAc/hexanes), $R_{\mathrm{f}}$ :
8.59 (s, 1H, ArH), 8.57-8.54 (m, 2H, ArH), 7.55-7.44

(m, 6H, ArH), 7.38-7.35 (m, 2H, ArH), 2.90 (tt, 1H, $J=$ $\left.11.5,3.5 \mathrm{~Hz},{ }^{c} \mathrm{C}_{6} \mathrm{H}_{11}\right), 1.94-1.69\left(\mathrm{~m}, 7 \mathrm{H},{ }^{c} \mathrm{C}_{6} \mathrm{H}_{11}\right), 1.37$ (qt, $\left.1 \mathrm{H}, J=12.8,3.2 \mathrm{~Hz},{ }^{c} \mathrm{C}_{6} \mathrm{H}_{11}\right), 1.30-1.20(\mathrm{~m}, 2 \mathrm{H}$, $\left.{ }^{c} \mathrm{C}_{6} \mathrm{H}_{11}\right)$.

$171.6,163.1,157.4,138.2,136.6,131.7,130.6,129.4$, $128.9,128.7,128.3,128.1,42.0,32.2,26.3,26.1$.

3060 (w), 2929 (s), 2853 (m), 1586 (w), 1568 (s), 1525 (s), $1425(\mathrm{~s}), 1378(\mathrm{~m})$.

calcd for $\mathrm{C}_{22} \mathrm{H}_{23} \mathrm{~N}_{2}[\mathrm{M}+\mathrm{H}]^{+}: 315.1861$, found: 315.1861 .

0.69 (UV, CAM). 


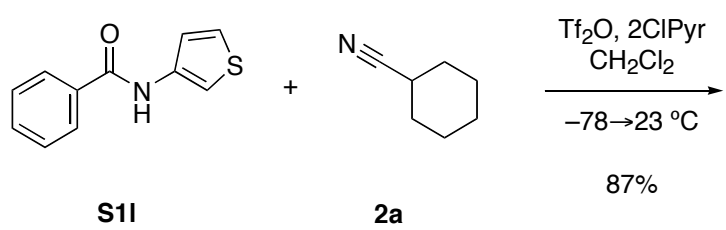

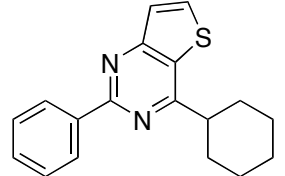

S3r

\section{4-Cyclohexyl-2-phenyl-thieno[3,2-d]pyrimidine (S3r, Table 2, entry 18):}

Trifluoromethanesulfonic anhydride $(72 \mu \mathrm{L}, 0.43 \mathrm{mmol}, 1.1$ equiv) was added via syringe over $1 \mathrm{~min}$ to a stirred mixture of amide $\mathbf{S 1 I}(80 \mathrm{mg}, 0.39 \mathrm{mmol}, 1$ equiv), nitrile $\mathbf{2 a}$ (47 $\mathrm{mg}, 0.54$ mmol, 1.1 equiv) and 2-chloropyridine ( $45 \mu \mathrm{L}, 0.47 \mathrm{mmol}, 1.2$ equiv) in dichloromethane $(1.3 \mathrm{~mL})$ at $-78^{\circ} \mathrm{C}$. After $5 \mathrm{~min}$, the reaction mixture was placed in an ice-water bath for 5 minutes and warmed to $0{ }^{\circ} \mathrm{C}$. The resulting solution was allowed to warm to ambient temperature. After $1 \mathrm{~h}$, aqueous sodium hydroxide solution $(1 \mathrm{~mL}, 1 \mathrm{~N})$ was introduced to neutralize the trifluoromethanesulfonate salts. Dichloromethane $(5 \mathrm{~mL})$ was added to dilute the mixture and the layers were separated. The organic layer was washed with brine $(2 \mathrm{~mL})$, was dried over anhydrous sodium sulfate, and was filtered. The volatiles were removed under reduced pressure and the residue was purified by flash column chromatography (eluent: $5 \%$ EtOAc in hexanes; $\mathrm{SiO}_{2}: 15 \times 1.5 \mathrm{~cm}$ ) on neutralized silica gel to give the pyrimidine product $\mathbf{S 3 r}$ as a pale yellow solid (101 $\mathrm{mg}, 87 \%)$.

${ }^{1} \mathrm{H}$ NMR $\left(500 \mathrm{MHz}, \mathrm{CDCl}_{3}, 20{ }^{\circ} \mathrm{C}\right) \delta: \quad 8.60-8.58(\mathrm{~m}, 2 \mathrm{H}, \mathrm{ArH}), 7.92(\mathrm{~d}, 1 \mathrm{H}, J=5.5 \mathrm{~Hz}, \operatorname{ArH})$, $7.60(\mathrm{~d}, 1 \mathrm{H}, J=5.5 \mathrm{~Hz}, \operatorname{ArH}), 7.54-7.48(\mathrm{~m}, 3 \mathrm{H}, \mathrm{ArH})$, $3.05\left(\mathrm{tt}, 1 \mathrm{H}, J=11.5,3.8 \mathrm{~Hz},{ }^{c} \mathrm{C}_{6} \mathbf{H}_{11}\right), 2.10-1.81(\mathrm{~m}, 7 \mathrm{H}$, $\left.{ }^{c} \mathrm{C}_{6} \mathbf{H}_{11}\right), 1.56-1.38\left(\mathrm{~m}, 3 \mathrm{H},{ }^{c} \mathrm{C}_{6} \mathbf{H}_{11}\right)$.

${ }^{13} \mathrm{C} \mathrm{NMR}\left(125 \mathrm{MHz}, \mathrm{CDCl}_{3}, 20{ }^{\circ} \mathrm{C}\right) \delta: \quad 168.8,162.0,161.4,138.7,134.5,130.3,128.7,128.5$, $127.4,125.4,46.3,31.3,26.5,26.2$.

FTIR (neat) $\mathrm{cm}^{-1}$ :

HRMS (ESI):

TLC (20\% EtOAc/hexanes), $R_{\mathrm{f}}$ : $2928(\mathrm{~m}), 2852(\mathrm{w}), 1535(\mathrm{~s}), 1365(\mathrm{w}), 1341(\mathrm{w})$.

calcd for $\mathrm{C}_{18} \mathrm{H}_{19} \mathrm{~N}_{2} \mathrm{~S}[\mathrm{M}+\mathrm{H}]^{+}: 295.1269$, found: 295.1259 .

$0.52(\mathrm{UV}, \mathrm{CAM})$ 


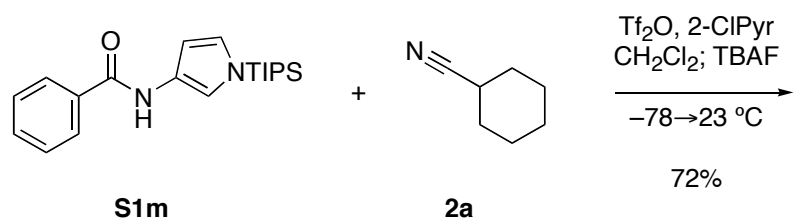

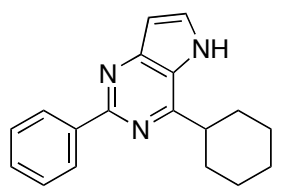

S3s

\section{4-Cyclohexyl-2-phenyl-5H-pyrrolo[3,2-d]pyrimidine (S3s, Table 2, entry 19):}

Trifluoromethanesulfonic anhydride $(37 \mu \mathrm{L}, 0.23 \mathrm{mmol}, 1.1$ equiv) was added via syringe over $1 \mathrm{~min}$ to a stirred mixture of amide $\mathbf{S 1 m}(70 \mathrm{mg}, 0.20 \mathrm{mmol}, 1$ equiv), nitrile $\mathbf{2 a}$ (46 $\mathrm{mg}, 0.41$ mmol, 2.00 equiv) and 2-chloropyridine (39 $\mu \mathrm{L}, 0.41 \mathrm{mmol}, 2.00$ equiv) in dichloromethane $(0.7 \mathrm{~mL})$ at $-78{ }^{\circ} \mathrm{C}$. After $5 \mathrm{~min}$, the reaction mixture was placed in an ice-water bath for 5 minutes and warmed to $0{ }^{\circ} \mathrm{C}$. The resulting solution was allowed to warm to ambient temperature. After $1 \mathrm{~h}$, triethylamine $(1 \mathrm{~mL})$ was introduced to neutralize the trifluoromethanesulfonate salts, followed by TBAF $(204 \mu \mathrm{L}, 1.00$ equiv, $1.0 \mathrm{M})$ to protodesilylate the pyrimidine product. Dichloromethane $(5$ $\mathrm{mL}$ ) was added to dilute the mixture and the layers were separated. The volatiles were removed under reduced pressure and the residue was purified by flash column chromatography (eluent: $10 \rightarrow 40 \%$ EtOAc in hexanes; $\mathrm{SiO}_{2}: 15 \times 1.5 \mathrm{~cm}$ ) on neutralized silica gel to give the pyrimidine product $\mathbf{S 3 s}$ as a pale tan solid (41 $\mathrm{mg}, 72 \%)$.

${ }^{1} \mathrm{H}$ NMR $\left(500 \mathrm{MHz}, \mathrm{CDCl}_{3}, 20{ }^{\circ} \mathrm{C}\right) \delta: \quad 8.57-8.52(\mathrm{~m}, 2 \mathrm{H}, \mathrm{ArH}), 8.45(\mathrm{~s}, 1 \mathrm{H}, \mathrm{NH}), 7.54-7.47$ (m, 3H, ArH), 7.45-7.40 (m, 1H, ArH), 6.79 (dd, 1H, J $=3.1,2.0 \mathrm{~Hz}, \operatorname{ArH}), 3.05(\mathrm{tt}, 1 \mathrm{H}, J=11.4,3.5 \mathrm{~Hz}$, $\left.{ }^{c} \mathrm{C}_{6} \mathbf{H}_{11}\right), 2.09-1.80\left(\mathrm{~m}, 7 \mathrm{H},{ }^{c} \mathrm{C}_{6} \mathbf{H}_{11}\right), 1.54-1.38(\mathrm{~m}, 3 \mathrm{H}$, $\left.{ }^{c} \mathrm{C}_{6} \mathbf{H}_{11}\right)$.

${ }^{13} \mathrm{C}$ NMR $\left(125 \mathrm{MHz}, \mathrm{DMF}-d_{7}, 20{ }^{\circ} \mathrm{C}\right) \delta: \quad 157.9,156.9,151.9,141.1,133.6,130.0,129.3,128.6$, 125.2, 102.9, 42.4, 32.2, 27.3, 27.0.

FTIR (neat) $\mathrm{cm}^{-1}$ :

3073 (m), 3019 (m), 2924 (s), 2849 (s), 1996 (w), 1738 (w), 1609 (m), 1543 (s), 1445 (m), 1386 (s).

HRMS (ESI):

calcd for $\mathrm{C}_{18} \mathrm{H}_{20} \mathrm{~N}_{3}[\mathrm{M}+\mathrm{H}]^{+}: 278.1657$, found: 278.1656.

TLC (40\% EtOAc/hexanes), $R_{\mathrm{f}}$ :

0.38 (UV, CAM).

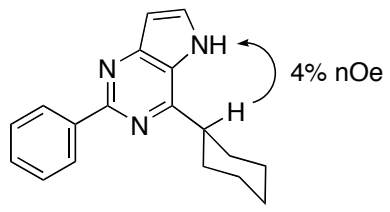

nOe data: 


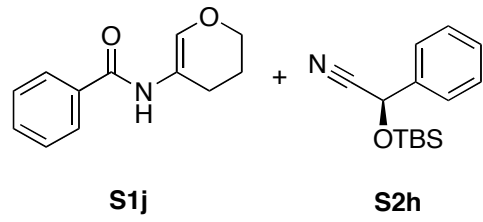

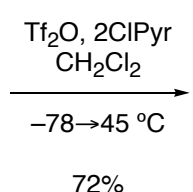

$72 \%$

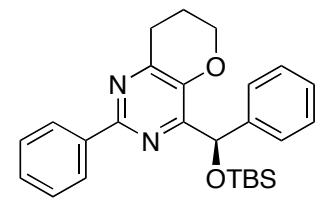

S3t, $96 \%$ ee

$\underline{(R)-4-[(t e r t-B u t y l-d i m e t h y l-s i l a n y l o x y)-p h e n y l-m e t h y l]-2-p h e n y l-7,8-d i h y d r o-6 H-p y r a n o[3,2-d ~}]$ pyrimi dine (S3t, Table 2, entry 20):

Trifluoromethanesulfonic anhydride $(54 \mu \mathrm{L}, 0.33 \mathrm{mmol}, 1.1$ equiv) was added via syringe over $1 \mathrm{~min}$ to a stirred mixture of amide $\mathbf{S l j}$ ( $60 \mathrm{mg}, 0.30 \mathrm{mmol}, 1$ equiv), nitrile $\mathbf{S 2 h}^{6}$ (219 $\mathrm{mg}, 0.885$ $\mathrm{mmol}, 3.00$ equiv) and 2-chloropyridine ( $34 \mu \mathrm{L}, 0.35 \mathrm{mmol}, 1.2$ equiv) in dichloromethane $(1.0 \mathrm{~mL})$ at $-78{ }^{\circ} \mathrm{C}$. After $5 \mathrm{~min}$, the reaction mixture was placed in an ice-water bath and warmed to $0{ }^{\circ} \mathrm{C}$, and the resulting solution was allowed to warm to ambient temperature for 5 minutes before being placed into a preheated oil bath at $45^{\circ} \mathrm{C}$ and maintained at that temperature. After $1 \mathrm{~h}$, the reaction vessel was allowed to cool to ambient temperature and aqueous sodium hydroxide solution $(1 \mathrm{~mL}, 1 \mathrm{~N})$ was introduced to neutralize the trifluoromethanesulfonate salts. Dichloromethane $(5 \mathrm{~mL})$ was added to dilute the mixture and the layers were separated. The organic layer was washed with brine $(2 \mathrm{~mL})$, was dried over anhydrous sodium sulfate, and was filtered. The volatiles were removed under reduced pressure and the residue was purified by flash column chromatography (eluent: $5 \% \mathrm{EtOAc}$ in hexanes; $\mathrm{SiO}_{2}: 15 \times 1.5 \mathrm{~cm}$ ) on neutralized silica gel to give the pyrimidine product $\mathbf{S 3 t}$ as a colorless oil (91 mg, 72\%, 96\% ee). The ee of the product was determined by chiral HPLC analysis of the corresponding desilylated alcohol. The enantiomeric excess of the pyrimidine product was determined to be $95 \%$ ee by chiral HPLC analysis [Chiralpak AD-H; $2.5 \mathrm{~mL} / \mathrm{min} ; 7 \%{ }^{i} \mathrm{PrOH}$ in hexanes; $t_{\mathrm{R}}($ minor $)=6.74 \mathrm{~min}, t_{\mathrm{R}}($ major $\left.)=9.95 \mathrm{~min}\right]$.

${ }^{1} \mathrm{H}$ NMR $\left(500 \mathrm{MHz}, \mathrm{CDCl}_{3}, 20^{\circ} \mathrm{C}\right) \delta: \quad 8.44-8.38(\mathrm{~m}, 2 \mathrm{H}, \mathrm{ArH}), 7.62-7.57(\mathrm{~m}, 2 \mathrm{H}, \mathrm{ArH}), 7.48$ 7.38 (m, 3H, ArH), 7.35-7.30 (m, 2H, ArH), 7.27-7.24 (m, 1H, ArH), 6.20 (s, 1H, CHOTBS), 4.32-4.21 (m, $2 \mathrm{H}, \mathrm{CH}_{2} \mathrm{CH}_{2} \mathrm{CH}_{2} \mathrm{O}$ ), 3.03-2.92 (m, 2H, $\mathrm{CH}_{2} \mathrm{CH}_{2} \mathrm{CH}_{2} \mathrm{O}$ ), 2.20-2.11 (m, 2H, $\left.\mathrm{CH}_{2} \mathrm{CH}_{2} \mathrm{CH}_{2} \mathrm{O}\right), 0.95$ (s, 9H, $\left.\mathrm{Si}\left(\mathrm{CH}_{3}\right)_{2} \mathrm{C}\left(\mathrm{CH}_{3}\right)_{3}\right), 0.05$ (s, 3H, $\left.\mathrm{Si}\left(\mathrm{CH}_{3}\right)_{2} \mathrm{C}\left(\mathrm{CH}_{3}\right)_{3}\right), 0.00$ (s, $\left.3 \mathrm{H}, \mathrm{Si}\left(\mathrm{CH}_{3}\right)_{2} \mathrm{C}\left(\mathrm{CH}_{3}\right)_{3}\right)$.

${ }^{13} \mathrm{C}$ NMR $\left(125 \mathrm{MHz}, \mathrm{CDCl}_{3}, 20{ }^{\circ} \mathrm{C}\right) \delta$ :

FTIR (neat) $\mathrm{cm}^{-1}$ :

HRMS (ESI):

TLC (20\% EtOAc/hexanes), $R_{\mathrm{f}}$ :
157.4, 156.0, 151.3, 145.7, 142.6, 138.3, 129.5, 128.5, $128.1,127.8,127.3,127.0,71.8,66.8,28.2,26.0,22.0$, $18.5,-4.5,-4.7$.

3065 (m), 3032 (m), 2954 (s), 2886 (s), 2856 (s), 1957 (w), 1819 (w), 1586 (m), 1564 (s), 1409 (s), 1252 (s).

calcd for $\mathrm{C}_{26} \mathrm{H}_{33} \mathrm{~N}_{2} \mathrm{O}_{2} \mathrm{Si}[\mathrm{M}+\mathrm{H}]^{+}$: 433.2311, found: 433.2303 .

0.67 (UV, CAM).

\footnotetext{
${ }^{6}$ The nitrile S2h was prepared by silylation of the corresponding commercially available cyanohydrin. The optical activity of the starting cyanohydrin was determined to be $96 \%$ ee by chiral HPLC analysis.
} 

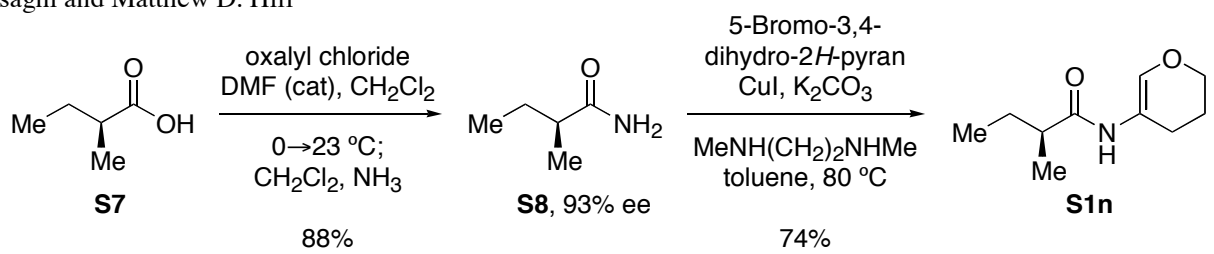

(S)-N-(5,6-Dihydro-4H-pyran-3-yl)-2-methyl-butyramide (S1n, Table 2, entry 21):

Oxalyl chloride (1.30 g, $10.3 \mathrm{mmol}, 1.05$ equiv) was added over 1 minute via syringe to a

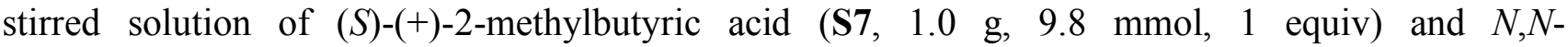
dimethylformamide $(10 \mu \mathrm{L})$ in dichloromethane $(33 \mathrm{~mL})$ in an ice-bath at $0{ }^{\circ} \mathrm{C}$. The reaction mixture was removed from the ice-bath after 15 minutes and allowed to warm to ambient temperature. After $1.5 \mathrm{~h}$, gas evolution had ceased and dichloromethane saturated with ammonia $(33 \mathrm{~mL})$ was added via cannula at ambient temperature. Water $(10 \mathrm{~mL})$ was added after 5 minutes to remove ammonium salts and the layers were separated. The aqueous layer was extracted with dichloromethane $(2 \times 50$ $\mathrm{mL})$, the organic layers were combined and dried over anhydrous sodium sulfate and filtered, and the volatiles were removed under reduced pressure to afford pure primary amide $\mathbf{S 8}$ as a white solid ( 870 $\mathrm{mg}, 88 \%$ ). The enantiomeric excess of the amide was determined to be $93 \%$ ee by chiral HPLC analysis [Chiralpak AD-H; $1.0 \mathrm{~mL} / \mathrm{min} ; 7 \%{ }^{i} \mathrm{PrOH}$ in hexanes; $t_{\mathrm{R}}$ (minor) $=14.2 \mathrm{~min}, t_{\mathrm{R}}($ major$)=$ $15.7 \mathrm{~min}]$. The primary amide $(850 \mathrm{mg}, 8.40 \mathrm{mmol}, 1$ equiv) was then combined with 5-Bromo-3,4dihydro-2 $H$-pyran ${ }^{7}$ (1.1 g, $7.0 \mathrm{mmol}, 0.83$ equiv), copper iodide (160 mg, $0.840 \mathrm{mmol}, 0.100$ equiv), $N, N^{\prime}$-dimethylethylenediamine (148 mg, $1.68 \mathrm{mmol}, 0.200$ equiv), and potassium carbonate $(1.97 \mathrm{~g}$, $14.3 \mathrm{mmol}, 1.70$ equiv) in toluene $(8.4 \mathrm{~mL})$ in a pressure vessel. The resulting reaction mixture was placed in a preheated oil bath at $80{ }^{\circ} \mathrm{C}$ and maintained at that temperature. After $16 \mathrm{~h}$, the solution was removed from the bath and allowed to cool to ambient temperature. The crude mixture was diluted with ethyl acetate $(30 \mathrm{~mL})$ and filtered through celite; the volatiles were removed under reduced pressure and the residue was purified by flash column chromatography (eluent: 40\% EtOAc in hexanes; $\mathrm{SiO}_{2}: 25 \times 3 \mathrm{~cm}$ ) on silica gel to give the amide product $\mathbf{S 1 n}$ as a white solid (950 mg, 74\%). The copper catalyzed $\mathrm{C}-\mathrm{N}$ bond formation occurred without loss of optical activity as confirmed by measuring the enantiomeric excess of the corresponding pyrimidine S3u (see page S24).

${ }^{1} \mathrm{H}$ NMR $\left(500 \mathrm{MHz}, \mathrm{CDCl}_{3}, 20{ }^{\circ} \mathrm{C}\right) \delta: \quad 6.93(\mathrm{~s}, 1 \mathrm{H}, \mathrm{C}=\mathrm{CH}), 6.15$ (br s, $\left.1 \mathrm{H}, \mathrm{NH}\right), 3.95(\mathrm{t}, 2 \mathrm{H}, J$ $\left.=5.3 \mathrm{~Hz}, \mathrm{CH}_{2} \mathrm{CH}_{2} \mathrm{CH}_{2} \mathrm{O}\right), 2.26-2.22(\mathrm{~m}, 2 \mathrm{H}$, $\left.\mathrm{CH}_{2} \mathrm{CH}_{2} \mathrm{CH}_{2} \mathrm{O}\right), 2.16-2.07\left(\mathrm{~m}, 1 \mathrm{H}, \mathrm{CH}\left(\mathrm{CH}_{3}\right) \mathrm{CH}_{2} \mathrm{CH}_{3}\right)$, $1.98-1.92\left(\mathrm{~m}, 2 \mathrm{H}, \mathrm{CH}_{2} \mathrm{CH}_{2} \mathrm{CH}_{2} \mathrm{O}\right), 1.74-1.64(\mathrm{~m}, 1 \mathrm{H}$, $\left.\mathrm{CH}\left(\mathrm{CH}_{3}\right) \mathrm{CH}_{2} \mathrm{CH}_{3}\right), 1.51-1.42\left(\mathrm{~m}, 1 \mathrm{H}, \mathrm{CH}\left(\mathrm{CH}_{3}\right) \mathrm{CH}_{2}\right.$ $\left.\mathrm{CH}_{3}\right), 1.16\left(\mathrm{~d}, 3 \mathrm{H}, J=6.7 \mathrm{~Hz}, \mathrm{CH}\left(\mathrm{CH}_{3}\right) \mathrm{CH}_{2} \mathrm{CH}_{3}\right), 0.94$ $\left(\mathrm{t}, 3 \mathrm{H}, J=7.4 \mathrm{~Hz}, \mathrm{CH}\left(\mathrm{CH}_{3}\right) \mathrm{CH}_{2} \mathrm{CH}_{3}\right)$.

${ }^{13} \mathrm{C}$ NMR $\left(125 \mathrm{MHz}, \mathrm{CDCl}_{3}, 20{ }^{\circ} \mathrm{C}\right) \delta: \quad 175.8,139.5,113.7,65.4,43.3,27.6,23.9,22.1,17.7$, 12.1 .

FTIR (neat) $\mathrm{cm}^{-1}$ : 3292 (w), 2968 (m), $2936(\mathrm{~m}), 2878(\mathrm{w}), 1727(\mathrm{~s}), 1699$ (m), $1651(\mathrm{~s}), 1510(\mathrm{~m}), 1463(\mathrm{~m}), 1382(\mathrm{w}), 1165(\mathrm{~m})$.

HRMS (ESI):

calcd for $\mathrm{C}_{10} \mathrm{H}_{18} \mathrm{NO}_{2}[\mathrm{M}+\mathrm{H}]^{+}: 184.1332$, found: 184.1337 .

TLC (40\% EtOAc in hexanes), $R_{\mathrm{f}}: \quad 0.34$ (UV, CAM).

\footnotetext{
${ }^{7}$ Bonner, W. A.; Werth, P. J.; Roth, J. M. J. Org. Chem. 1962, 27, 1575.
} 

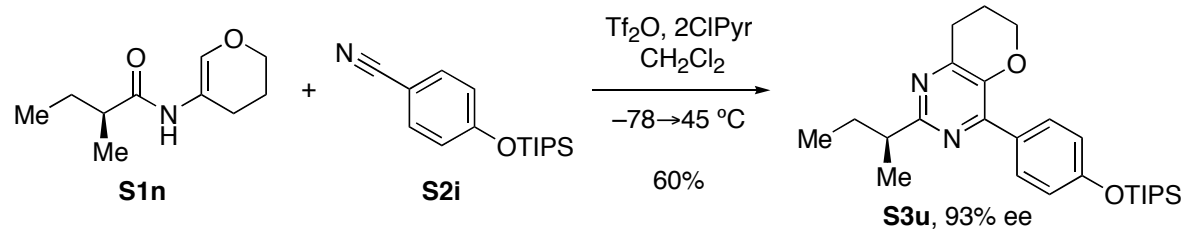

(S)-2-sec-Butyl-4-[4-(triisopropyl-silanyloxy)-phenyl]-7,8-dihydro-6H-pyrano[3,2-d]pyrimidine (S3u, Table 2, entry 21):

Trifluoromethanesulfonic anhydride $(79 \mu \mathrm{L}, 0.48 \mathrm{mmol}, 1.1$ equiv) was added via syringe over $1 \mathrm{~min}$ to a stirred mixture of amide Sln ( $80 \mathrm{mg}, 0.44 \mathrm{mmol}, 1$ equiv), nitrile S2i (361 mg, 1.31 mmol, 3.00 equiv) and 2-chloropyridine ( $50 \mu \mathrm{L}, 0.52 \mathrm{mmol}, 1.2$ equiv) in dichloromethane $(1.5 \mathrm{~mL})$ at $-78{ }^{\circ} \mathrm{C}$. After $5 \mathrm{~min}$, the reaction mixture was placed in an ice-water bath and warmed to $0{ }^{\circ} \mathrm{C}$, and the resulting solution was allowed to warm to ambient temperature for 5 minutes before being placed into a preheated oil bath at $45^{\circ} \mathrm{C}$ and maintained at that temperature. After $1 \mathrm{~h}$, the reaction vessel was allowed to cool to ambient temperature and aqueous sodium hydroxide solution $(1 \mathrm{~mL}, 1 \mathrm{~N})$ was introduced to neutralize the trifluoromethanesulfonate salts. Dichloromethane $(5 \mathrm{~mL})$ was added to dilute the mixture and the layers were separated. The organic layer was washed with brine $(2 \mathrm{~mL})$, was dried over anhydrous sodium sulfate, and was filtered. The volatiles were removed under reduced pressure and the residue was purified by flash column chromatography (eluent: $10 \rightarrow 20 \%$ EtOAc in hexanes; $\mathrm{SiO}_{2}: 15 \times 1.5 \mathrm{~cm}$ ) on neutralized silica gel to give the pyrimidine product $\mathbf{S 3} \mathbf{u}$ as a colorless oil $(115 \mathrm{mg}, 60 \%)$. The enantiomeric excess of the pyrimidine product was determined to be $93 \%$ ee by protodesilylation and chiral HPLC analysis [Chiralpak AD-H; $2.0 \mathrm{~mL} / \mathrm{min} ; 3 \%{ }^{i} \mathrm{PrOH}$ in hexanes; $t_{\mathrm{R}}($ major $)=9.36 \mathrm{~min}, t_{\mathrm{R}}($ minor $\left.)=11.1 \mathrm{~min}\right]$ of the corresponding alcohol. ${ }^{8}$

${ }^{1} \mathrm{H}$ NMR $\left(500 \mathrm{MHz}, \mathrm{CDCl}_{3}, 2{ }^{\circ} \mathrm{C}\right) \delta: \quad 8.16-8.12(\mathrm{~m}, 2 \mathrm{H}, \operatorname{Ar} \mathbf{H}), 6.97-6.93(\mathrm{~m}, 2 \mathrm{H}, \mathrm{ArH}), 4.28$ (t, $\left.2 \mathrm{H}, J=5.1 \mathrm{~Hz}, \mathrm{CH}_{2} \mathrm{CH}_{2} \mathrm{CH}_{2} \mathrm{O}\right), 2.98-2.87(\mathrm{~m}, 3 \mathrm{H}$, $\left.\mathrm{CH}_{2} \mathrm{CH}_{2} \mathrm{CH}_{2} \mathrm{O}, \mathrm{CH}\left(\mathrm{CH}_{3}\right) \mathrm{CH}_{2} \mathrm{CH}_{3}\right), 2.20-2.15(\mathrm{~m}, 2 \mathrm{H}$, $\left.\mathrm{CH}_{2} \mathrm{CH}_{2} \mathrm{CH}_{2} \mathrm{O}\right), 1.96-1.86\left(\mathrm{~m}, 1 \mathrm{H}, \mathrm{CH}\left(\mathrm{CH}_{3}\right) \mathrm{CH}_{2} \mathrm{CH}_{3}\right)$, $1.70-1.61\left(\mathrm{~m}, 1 \mathrm{H}, \mathrm{CH}\left(\mathrm{CH}_{3}\right) \mathrm{CH}_{2} \mathrm{CH}_{3}\right), 1.34-1.26(\mathrm{~m}, 6 \mathrm{H}$, $\left.\mathrm{CH}\left(\mathrm{CH}_{3}\right) \mathrm{CH}_{2} \mathrm{CH}_{3}, \mathrm{Si}\left(\mathrm{CH}\left(\mathrm{CH}_{3}\right)_{2}\right)_{3}\right), 1.14(\mathrm{~d}, 18 \mathrm{H}, J=$ $\left.7.5 \mathrm{~Hz}, \mathrm{Si}\left(\mathrm{CH}\left(\mathrm{CH}_{3}\right)_{2}\right)_{3}\right), 0.90(\mathrm{t}, 3 \mathrm{H}, J=7.4 \mathrm{~Hz}$, $\left.\mathrm{CH}\left(\mathrm{CH}_{3}\right) \mathrm{CH}_{2} \mathrm{CH}_{3}\right)$.

${ }^{13} \mathrm{C}$ NMR $\left(125 \mathrm{MHz}, \mathrm{CDCl}_{3}, 20{ }^{\circ} \mathrm{C}\right) \delta$ :

FTIR (neat) $\mathrm{cm}^{-1}$ :

HRMS (EI):

TLC (20\% EtOAc in hexanes), $R_{\mathrm{f}}$ :
$165.5,157.7,151.4,150.9,145.6,131.3,128.9,119.5$, $66.7,44.2,29.6,28.4,22.1,20.0,18.1,12.9,12.4$.

2961 (s), 2868 (s), 1605 (s), 1558 (m), 1541 (w), 1508 (s), $1463(\mathrm{~m}), 1270(\mathrm{~s})$.

calcd for $\mathrm{C}_{26} \mathrm{H}_{40} \mathrm{~N}_{2} \mathrm{O}_{2} \mathrm{Si}[\mathrm{M}]^{+}: 440.2859$, found: 440.2865 .

0.37 (UV, CAM)

\footnotetext{
${ }^{8}$ The use of the (S)-N-(4-methoxyphenyl)-2-methylbutyramide variant of amide $\mathbf{S 1 n}$ as the substrate with the same nitrile (S2i, 1.1 equiv) under standard conditions ( $\mathrm{B}$ or $\mathrm{C}$, see text) provided the corresponding quinazoline in $58 \%$ yield (condition $\mathrm{C}$ ) but with complete racemization $(0 \%$ ee). This is likely due to the compounded effect of the low reactivity of the amide and the nitrile in addition to the likely slower rate of cyclization of intermediate $\mathbf{6}$ (Scheme 1) leading to quinazolines.
} 


\section{Direct conversion of secondary amide 1a and primary amide 4 to quinazoline $3 \mathrm{a}$.}
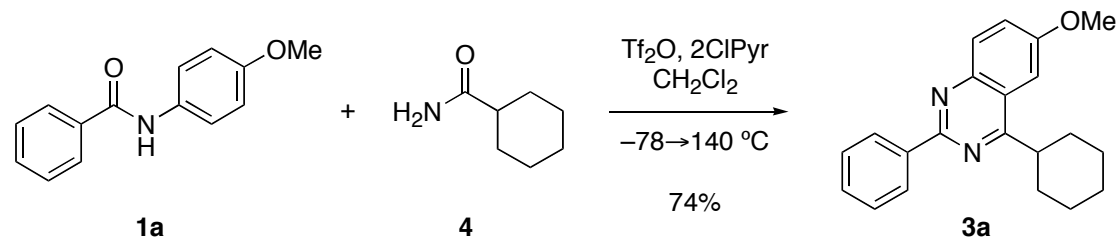

\section{4-Cyclohexyl-6-methoxy-2-phenyl-quinazoline (eq 2):}

Trifluoromethanesulfonic anhydride $(193 \mu \mathrm{L}, 1.17 \mathrm{mmol}, 2.30$ equiv) was added via syringe over $1 \mathrm{~min}$ to a stirred mixture of amide $1 \mathrm{a}(115 \mathrm{mg}, 0.506 \mathrm{mmol}, 1$ equiv), cyclohexanecarboxamide 4 (71 mg, $0.56 \mathrm{mmol}, 1.1$ equiv) and 2-chloropyridine (125 $\mu \mathrm{L}, 1.32 \mathrm{mmol}, 2.60$ equiv) in dichloromethane $(1.7 \mathrm{~mL})$ at $-78^{\circ} \mathrm{C}$. After $5 \mathrm{~min}$, the reaction mixture was placed in an ice-water bath for 5 minutes and warmed to $0{ }^{\circ} \mathrm{C}$. The resulting solution was warmed to ambient temperature for 5 minutes before the reaction vessel was placed into a microwave reactor and heated to $140{ }^{\circ} \mathrm{C}$. After $20 \mathrm{~min}$, the reaction vessel was removed from the microwave reactor and allowed to cool to ambient temperature before aqueous sodium hydroxide solution $(1 \mathrm{~mL}, 1 \mathrm{~N})$ was introduced to neutralize the trifluoromethanesulfonate salts. Dichloromethane $(5 \mathrm{~mL})$ was added to dilute the mixture and the layers were separated. The organic layer was washed with brine $(2 \mathrm{~mL})$, was dried over anhydrous sodium sulfate, and was filtered. The volatiles were removed under reduced pressure and the residue was purified by flash column chromatography (eluent: 5\% EtOAc in hexanes; $\mathrm{SiO}_{2}$ : $15 \times 1.5 \mathrm{~cm})$ on neutralized silica gel to give the quinazoline product $\mathbf{3 a}$ as a white solid $(119 \mathrm{mg}$, $74 \%)$.

See page S3 for spectroscopic data. 


\section{In situ IR analysis of the conversion of amide 1a and nitrile 2a to quinazoline 3a:}

All reactions were performed in a reaction vessel under an atmosphere of argon with the React-IR probe submerged completely in the reaction mixture.

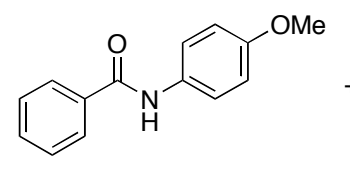

$1 \mathbf{a}$

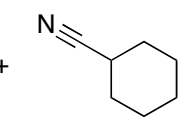

$\mathbf{2 a}$

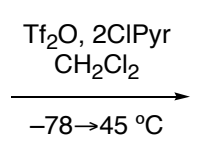

$63 \%$

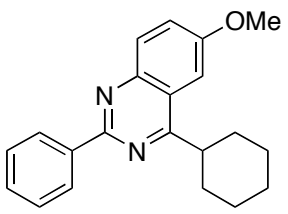

3a

\section{4-Cyclohexyl-6-methoxy-2-phenyl-quinazoline (3a):}

In situ IR monitoring of the addition of trifluoromethanesulfonic anhydride ( $96 \mu \mathrm{L}, 0.58 \mathrm{mmol}$, 1.1 equiv) via syringe over $1 \mathrm{~min}$ to a mixture of amide $1 \mathrm{a}(120 \mathrm{mg}, 0.528 \mathrm{mmol}, 1$ equiv) and 2chloropyridine $\left(60 \mu \mathrm{L}, 0.63 \mathrm{mmol}, 1.2\right.$ equiv) in dichloromethane $(2.7 \mathrm{~mL})$ at $0{ }^{\circ} \mathrm{C}$ revealed consumption of both amide 1a and 2-chloropyridine with concomitant appearance of a persistent band at $1600 \mathrm{~cm}^{-1}$ corresponding to the activated compound. After $5 \mathrm{~min}$, nitrile $2 \mathrm{a}$ (63 $\mathrm{mg}, 0.58$ mmol, 1.1 equiv) was added via syringe, and the resulting solution was placed into a preheated oil bath at $45{ }^{\circ} \mathrm{C}$ and maintained at that temperature. After $6 \mathrm{~h}$, the reaction vessel was allowed to cool to ambient temperature and aqueous sodium hydroxide solution $(1 \mathrm{~mL}, 1 \mathrm{~N})$ was introduced to neutralize the trifluoromethanesulfonate salts. Dichloromethane $(5 \mathrm{~mL})$ was added to dilute the mixture and the layers were separated. The organic layer was washed with brine $(2 \mathrm{~mL})$, was dried over anhydrous sodium sulfate, and was filtered. The volatiles were removed under reduced pressure and the residue was purified by flash column chromatography (eluent: 20\% EtOAc in hexanes; $\mathrm{SiO}_{2}$ : $15 \times 1.5 \mathrm{~cm}$ ) on neutralized silica gel to give the quinazoline product 3a as a white solid (106 mg, $63 \%$ ). See page S3 for full characterization of product 3a. See control experiments for assignment of observed band (page S27). ${ }^{8}$

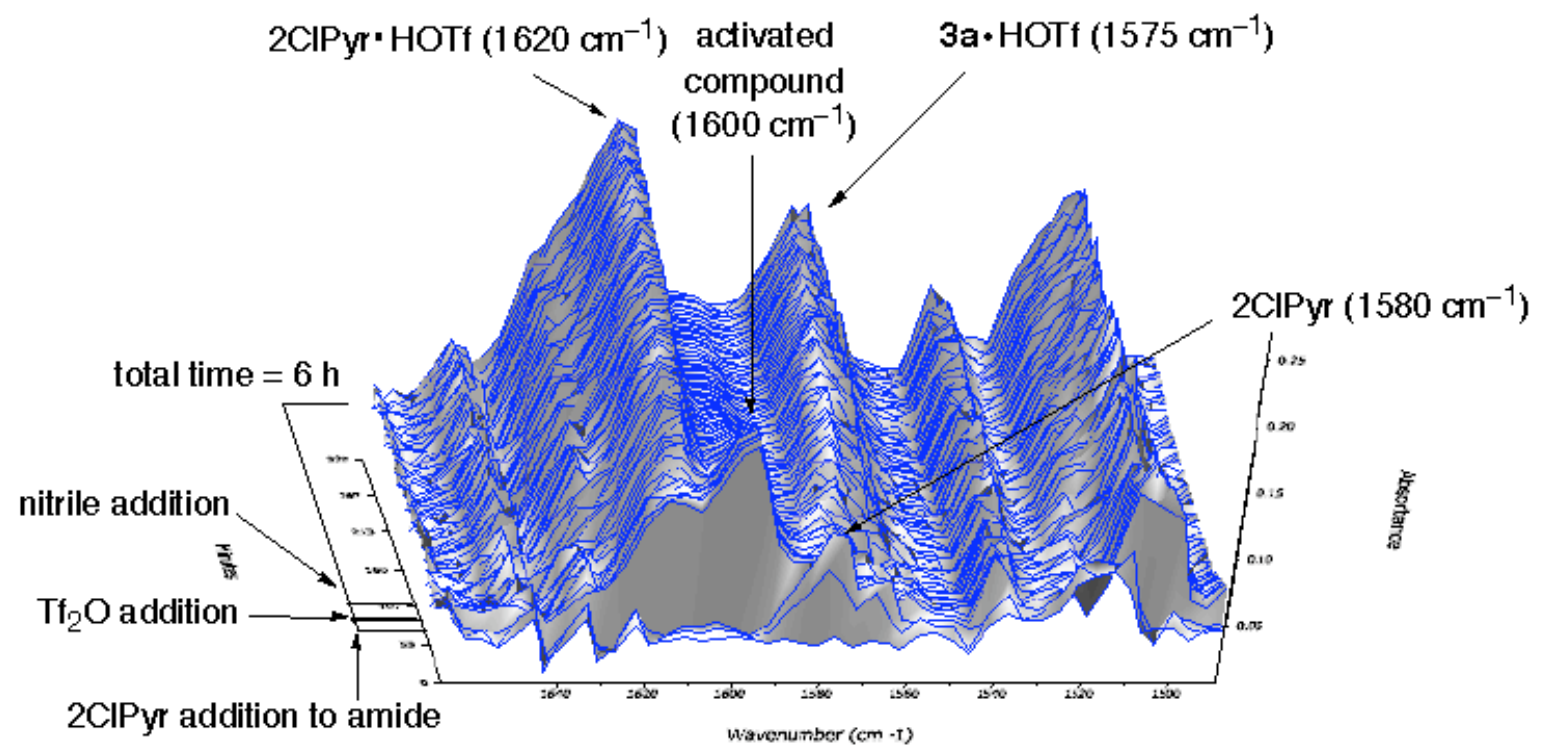

\footnotetext{
${ }^{8}$ Dines, T. J.; MacGregor, L. D.; Rochester, C. H. Spectrochimica Acta Part A 2003, 59, 3205-3217.
} 


\section{Control IR Experiments:}

Assignment of the 2-chloropyridine and the 2-chloropyridinium triflate characteristic stretches:

1) In situ IR monitoring of the addition of trifluoromethanesulfonic acid ( $47 \mu \mathrm{L}, 0.53 \mathrm{mmol}, 1$ equiv) via syringe to a solution of 2-chloropyridine (50 $\mu \mathrm{L}, 0.53 \mathrm{mmol}, 1$ equiv, $\left.1580 \mathrm{~cm}^{-1}\right)$ in $\mathrm{CH}_{2} \mathrm{Cl}_{2}$ $(2.2 \mathrm{~mL})$ at $0{ }^{\circ} \mathrm{C}$ resulted in the expected 2-chloropyridinium triflate salt $\left(1620 \mathrm{~cm}^{-1}\right)$.

Assignment of the 4-Cyclohexyl-6-methoxy-2-phenyl-quinazolin-1-ium triflate $(3 a \cdot H O T f)$ characteristic stretch:

2) In situ IR monitoring of the addition of trifluoromethanesulfonic acid ( $78 \mu \mathrm{L}, 0.88 \mathrm{mmol}, 2.0$ equiv) via syringe to a solution of quinazoline 3a (140 mg, $0.29 \mathrm{mmol}, 1$ equiv, $\left.1550 \mathrm{~cm}^{-1}\right)$ and 2chloropyridine $\left(50 \mu \mathrm{L}, 0.53 \mathrm{mmol}, 1\right.$ equiv, $\left.1580 \mathrm{~cm}^{-1}\right)$ in $\mathrm{CH}_{2} \mathrm{Cl}_{2}(2.2 \mathrm{~mL})$ at $0{ }^{\circ} \mathrm{C}$ resulted in the expected mixture containing 2-chloropyridinium triflate salt $\left(1620 \mathrm{~cm}^{-1}\right)$ and the 4-cyclohexyl-6methoxy-2-phenyl-quinazolin-1-ium triflate salt (3a•HOTf, $\left.1575 \mathrm{~cm}^{-1}\right)$.

3) The same characteristic resonance for $\mathbf{3} \mathbf{a} \cdot H O T f$ was observed in the absence of 2chloropyridine. In situ IR monitoring of the addition of trifluoromethanesulfonic acid ( $43 \mu \mathrm{L}, 0.49$ mmol, 1 equiv) to a solution of quinazoline 3a (140 mg, $0.29 \mathrm{mmol}, 1$ equiv, $1550 \mathrm{~cm}^{-1}$ ) in $\mathrm{CH}_{2} \mathrm{Cl}_{2}$ $(2.2 \mathrm{~mL})$ at $0{ }^{\circ} \mathrm{C}$ resulted in the expected 4-cyclohexyl-6-methoxy-2-phenyl-quinazolin-1-ium triflate salt (3a•HOTf, $\left.1575 \mathrm{~cm}^{-1}\right)$.

Assignment of the characteristic stretch at $1600 \mathrm{~cm}^{-1}$ to the activated intermediate in the presence of 2-chloropyridine:

4) Trifluoromethanesulfonic anhydride (96 $\mu \mathrm{L}, 0.58 \mathrm{mmol}, 1.1$ equiv) was added via syringe over $1 \mathrm{~min}$ to a solution of amide $1 \mathrm{a}(120 \mathrm{mg}, 0.528 \mathrm{mmol}, 1$ equiv) in dichloromethane $(2.7 \mathrm{~mL})$ at $0{ }^{\circ} \mathrm{C}$. After $5 \mathrm{~min}, 2$-chloropyridine $(60 \mu \mathrm{L}, 0.63 \mathrm{mmol}, 1.2$ equiv) was added via syringe resulting in the appearance of the characteristic stretch at $1600 \mathrm{~cm}^{-1}$. The nitrile $2 \mathbf{a}(63 \mathrm{mg}, 0.58 \mathrm{mmol}, 1.1$ equiv) was immediately added via syringe, and the resulting solution was placed into a preheated oil bath at $45^{\circ} \mathrm{C}$ and maintained at that temperature. After $3 \mathrm{~h}$, the reaction mixture was allowed to cool to ambient temperature and aqueous sodium hydroxide solution $(1 \mathrm{~mL}, 1 \mathrm{~N})$ was introduced to neutralize the trifluoromethanesulfonate salts. Dichloromethane $(5 \mathrm{~mL})$ was added to dilute the mixture and the layers were separated. The organic layer was washed with brine $(2 \mathrm{~mL})$, was dried over anhydrous sodium sulfate, and was filtered. The volatiles were removed under reduced pressure and the residue was purified by flash column chromatography (eluent: $20 \%$ EtOAc in hexanes; $\mathrm{SiO}_{2}: 15 \times 1.5 \mathrm{~cm}$ ) on neutralized silica gel to give the quinazoline product $\mathbf{3 a}$ as a white solid (58 $\mathrm{mg}, 35 \%$ ). This nonideal procedure (order of reagent addition and time) was used to verify the involvement of 2chloropyridine in the formation of the activated intermediate resulting in the observed stretch at 1600 $\mathrm{cm}^{-1}$.

5) Additionally, in situ IR monitoring of the addition of trifluoromethanesulfonic anhydride (73 $\mu \mathrm{L}, 0.44 \mathrm{mmol}, 1$ equiv) via syringe to 2-chloropyridine ( $42 \mu \mathrm{L}, 0.44 \mathrm{mmol}, 1$ equiv, $\left.1580 \mathrm{~cm}^{-1}\right)$ in $\mathrm{CH}_{2} \mathrm{Cl}_{2}(2.2 \mathrm{~mL})$ at ambient temperature resulted in no observable change. The band at $1580 \mathrm{~cm}^{-1}$ related to 2-chloropyridine persisted with out loss in intensity. After $4.5 \mathrm{~h}$, water $(70 \mu \mathrm{L}, 4.4 \mathrm{mmol}$, 10 equiv) was added via syringe and as expected the 2 -chloropyridine stretch $\left(1580 \mathrm{~cm}^{-1}\right)$ disappeared completely with a concomitant appearance of a band consistent with 2-chloropyridinium triflate salt $\left(1620 \mathrm{~cm}^{-1}\right)$. 


\section{${ }^{1} H$ and ${ }^{19}$ F NMR monitoring of the conversion of amide 1a and nitrile 2a to quinazoline 3a:}

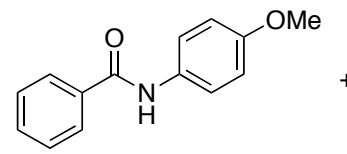

$1 \mathbf{a}$

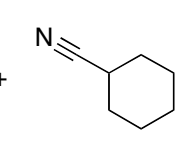

$2 a$

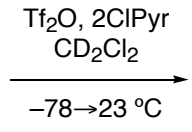

$-78 \rightarrow 23{ }^{\circ} \mathrm{C}$

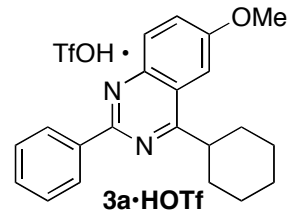

\section{4-Cyclohexyl-6-methoxy-2-phenyl-quinazoline (3a・HOTf):}

Trifluoromethanesulfonic anhydride $(80 \mu \mathrm{L}, 0.48 \mathrm{mmol}, 1.1$ equiv) was added via syringe over $1 \mathrm{~min}$ to a stirred mixture of amide $1 \mathrm{a}(100 \mathrm{mg}, 0.440 \mathrm{mmol}, 1$ equiv) and 2-chloropyridine (50 $\mu \mathrm{L}$, $0.53 \mathrm{mmol}, 1.2$ equiv) in $\mathrm{CD}_{2} \mathrm{Cl}_{2}(1.5 \mathrm{~mL})$ at $-78^{\circ} \mathrm{C}$. After $5 \mathrm{~min}$ the reaction vessel was placed in an ice-water bath and warmed to $0{ }^{\circ} \mathrm{C} .{ }^{1} \mathrm{H}(500 \mathrm{MHz})$ and ${ }^{19} \mathrm{~F}(282 \mathrm{MHz}) \mathrm{NMR}$ analysis revealed broad resonances. Additionally, complete consumption of 2-chloropyridine and the starting amide 1a was confirmed. ${ }^{19} \mathrm{~F}$ NMR was informative and revealed a broad peak corresponding to a triflate ion at $\delta$ 79.6 along with remaining trifluoromethanesulfonic anhydride $(\delta-72.4, \sim 16 \%)$. The nitrile $2 \mathrm{a}(53 \mathrm{mg}$, $0.48 \mathrm{mmol}, 1.1$ equiv) was added via syringe. After $5 \mathrm{~min},{ }^{1} \mathrm{H}$ and ${ }^{19} \mathrm{~F}$ NMR analysis revealed a small set of resonances consistent with the protonated quinazoline product 3a・HOTf along with dominant resonances corresponding to those observed during activation of the amide as described above. Again, the ${ }^{19} \mathrm{~F}$ NMR was informative and revealed predominantly a broad resonance corresponding to a triflate ion at $\delta-79.6$ along with un-reacted trifluoromethanesulfonic anhydride $(13 \%)$ at $\delta-72.4$. While a trace amount of the product was observed, the best conditions for the synthesis of 3a involve heating to $140{ }^{\circ} \mathrm{C}$.
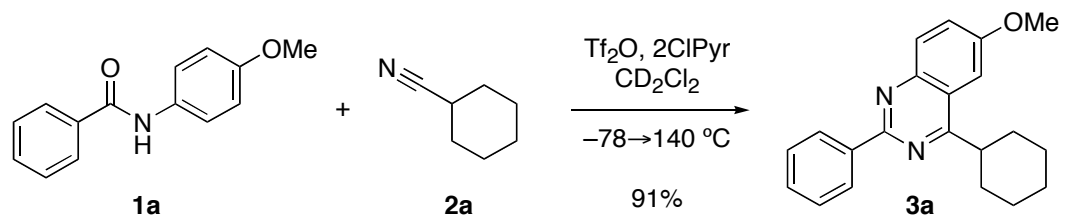

\section{4-Cyclohexyl-6-methoxy-2-phenyl-quinazoline (3a):}

Trifluoromethanesulfonic anhydride $(80 \mu \mathrm{L}, 0.48 \mathrm{mmol}, 1.1$ equiv) was added via syringe over $1 \mathrm{~min}$ to a stirred mixture of amide $1 \mathbf{a}(100 \mathrm{mg}, 0.440 \mathrm{mmol}, 1$ equiv), nitrile $\mathbf{2 a}$ (53 $\mathrm{mg}, 0.48$ mmol, 1.1 equiv) and 2-chloropyridine $\left(50 \mu \mathrm{L}, 0.53 \mathrm{mmol}, 1.2\right.$ equiv) in $\mathrm{CD}_{2} \mathrm{Cl}_{2}(1.5 \mathrm{~mL})$ at $-78^{\circ} \mathrm{C}$. After $5 \mathrm{~min}$, the reaction vessel was placed in an ice-water bath for 5 minutes and warmed to $0{ }^{\circ} \mathrm{C}$; the resulting solution was allowed to warm to ambient temperature for 5 minutes before the reaction vessel was placed into a microwave reactor and heated to $140^{\circ} \mathrm{C}$. After $20 \mathrm{~min}$, the reaction vessel was removed from the microwave reactor and a sample was subject to ${ }^{1} \mathrm{H}(500 \mathrm{MHz})$ and ${ }^{19} \mathrm{~F}$ NMR $(282 \mathrm{MHz})$ analysis. Complete conversion to the desired product was observed by this crude ${ }^{1} \mathrm{H}$ NMR analysis. The observed resonances corresponded to 2-chloropyridium trifluoromethanesulfonate, protonated quinazoline 3a•HOTf, and the remaining nitrile $\mathbf{2 a} .{ }^{19} \mathrm{~F}$ NMR analysis of the crude reaction mixture revealed only a broad resonance corresponding to triflate anion at $\delta-79.6$ and weak resonance at $\delta-72.4$ for the trace amount of remaining trifluoromethanesulfonic anhydride. Aqueous sodium hydroxide solution $(1 \mathrm{~mL}, 1 \mathrm{~N})$ was introduced to neutralize the trifluoromethanesulfonate salts. Dichloromethane $(5 \mathrm{~mL})$ was added to dilute the mixture and the layers were separated. The organic layer was washed with brine $(2 \mathrm{~mL})$, was dried over anhydrous sodium sulfate, and was filtered. The volatiles were removed under reduced pressure and the residue was purified by flash column chromatography (eluent: $10 \%$ EtOAc in hexanes; $\mathrm{SiO}_{2}: 15 \times 1.5 \mathrm{~cm}$ ) on 
neutralized silica gel to give the quinazoline product 3a as a white solid (127 $\mathrm{mg}, 91 \%)$. See page S3 for full characterization of the quinazoline product $\mathbf{3 a}$.

\section{Control ${ }^{1} \mathbf{H}$ and ${ }^{19}$ F NMR Experiments:}

Assignment of the 2-chloropyridinium triflate resonances:

1) Addition of trifluoromethanesulfonic acid (1 equiv) via syringe to 2-chloropyridine (1 equiv) in $\mathrm{CD}_{2} \mathrm{Cl}_{2}(700 \mu \mathrm{L})$ at $23{ }^{\circ} \mathrm{C}$ followed by ${ }^{1} \mathrm{H}$ and ${ }^{19} \mathrm{~F}$ NMR analysis revealed the formation of the expected 2-chloropyridinium triflate. ${ }^{1} \mathrm{H}$ NMR (500 MHz) $\delta: 15.8$ (br-s, 1H), 8.76 (br-m, 1H), 8.54 $(\mathrm{m}, 1 \mathrm{H}), 8.02-7.98(\mathrm{~m}, 2 \mathrm{H}) .{ }^{19} \mathrm{~F}$ NMR $(282 \mathrm{MHz}) \delta:-79.3$.

2) Consistent with the IR experiments described above, the addition of trifluoromethanesulfonic anhydride ( $32 \mu \mathrm{L}, 0.19 \mathrm{mmol}, 1.1$ equiv) via syringe to a solution of 2-chloropyridine (17 $\mu \mathrm{L}, 0.18$ mmol, 1 equiv) in $\mathrm{CD}_{2} \mathrm{Cl}_{2}(600 \mu \mathrm{L})$ at $23{ }^{\circ} \mathrm{C}$ under an atmosphere of argon followed by ${ }^{1} \mathrm{H}$ and ${ }^{19} \mathrm{~F}$ NMR analysis revealed no change after $24 \mathrm{~h}$. Importantly, ${ }^{19} \mathrm{~F}$ NMR (282 MHz) analysis only reveals a persistent resonance at $\delta-72.4\left(\mathrm{Tf}_{2} \mathrm{O}\right)$. After 24 hours, water $(50 \mu \mathrm{L})$ was added to this sample to give the expected 2-chloropyridinium triflate $(\delta-79.5)$.

Assignment of the 4-Cyclohexyl-6-methoxy-2-phenyl-quinazolin-1-ium triflate $(3 a \cdot H O T f)$ resonances: 3) Addition of trifluoromethanesulfonic acid (56 $\mu \mathrm{L}, 0.63 \mathrm{mmol}, 2.0$ equiv) via syringe to a solution of 2-chloropyridine ( $36 \mu \mathrm{L}, 0.38 \mathrm{mmol}, 1.2$ equiv) and quinazoline 3a (100 mg, $0.310 \mathrm{mmol}$, 1 equiv) in $\mathrm{CD}_{2} \mathrm{Cl}_{2}(1 \mathrm{~mL})$ at $23{ }^{\circ} \mathrm{C}$ followed by ${ }^{1} \mathrm{H}$ and ${ }^{19} \mathrm{~F} \mathrm{NMR}$ analysis revealed the formation of the expected 2-chloropyridinium triflate and the 4-cyclohexyl-6-methoxy-2-phenyl-quinazolin-1-ium triflate (3a•HOTf). ${ }^{1} \mathrm{H}$ NMR (500 MHz) $\delta:{ }^{1} \mathrm{H}$ NMR (500 MHz) $\delta: 14.9$ (br-s, 2.6H), 9.05 (br-s, $2.2 \mathrm{H}), 8.72(\mathrm{dd}, 1.1 \mathrm{H}, J=5.5,1.8 \mathrm{~Hz}), 8.70-8.63(\mathrm{~m}, 3.0 \mathrm{H}), 8.28$ (ddd, $1.0 \mathrm{H}, J=8.2,7.7,1.9 \mathrm{~Hz})$, $7.92(\mathrm{dd}, 0.9 \mathrm{H}, J=9.3,2.6 \mathrm{~Hz}), 7.82-7.75(\mathrm{~m}, 2.8 \mathrm{H}), 7.75-7.70(\mathrm{~m}, 2.0 \mathrm{H}), 7.61(\mathrm{~d}, 1.1 \mathrm{H}, J=2.7 \mathrm{~Hz})$, $4.10(\mathrm{~s}, 3.0 \mathrm{H}), 3.74(\mathrm{tt}, 1.1 \mathrm{H}, J=11.4,3.4 \mathrm{~Hz}), 2.14-1.90(\mathrm{~m}, 7.2 \mathrm{H}), 1.70-1.59(\mathrm{~m}, 2.1 \mathrm{H}), 1.48(\mathrm{qt}$, $1.1 \mathrm{H}, J=13.0,3.5 \mathrm{~Hz}) .{ }^{19} \mathrm{~F}$ NMR $(282 \mathrm{MHz}) \delta:-79.6$.

4) Addition of trifluoromethanesulfonic acid (56 $\mu \mathrm{L}, 0.63 \mathrm{mmol}, 2.0$ equiv) via syringe to a solution of quinazoline $3 \mathbf{a}\left(100 \mathrm{mg}, 0.310 \mathrm{mmol}, 1\right.$ equiv) in $\mathrm{CD}_{2} \mathrm{Cl}_{2}(1 \mathrm{~mL})$ at $23{ }^{\circ} \mathrm{C}$ followed by ${ }^{19} \mathrm{~F}$ NMR analysis of the mixture suggests mono-protonation to give the quinazolinium triflate $\mathbf{3 a} \cdot \mathrm{HOTf}$. ${ }^{19}$ F NMR (282 MHz) $\delta:-78.0,-79.1$.

\section{${ }^{13} \mathrm{C}$ NMR monitoring of the conversion of amide $1 \mathrm{a}-{ }^{13} \mathrm{C}$ and nitrile $2 \mathrm{a}$ to quinazoline $3 \mathrm{a}-{ }^{13} \mathrm{C}$ :}
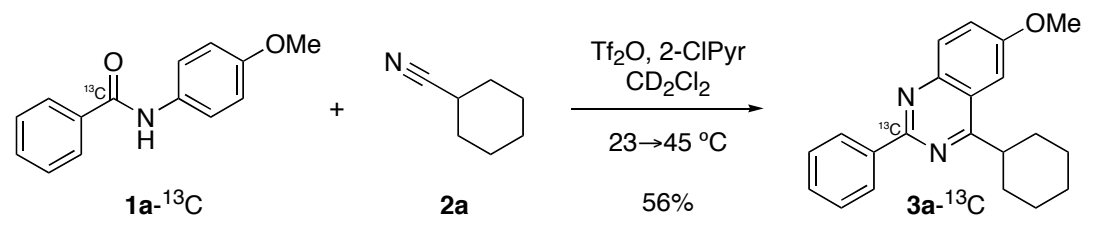

4-Cyclohexyl-6-methoxy-2-phenyl-quinazoline $-{ }^{13} \mathrm{C}\left(3 \mathrm{a}-{ }^{13} \mathrm{C}\right):$

2-Chloropyridine ( $50 \mu \mathrm{L}, 0.53 \mathrm{mmol}, 1.2$ equiv) was added via syringe to a solution of amide ${ }^{9}$ $1 \mathbf{a}^{13} \mathrm{C}\left({ }^{13} \mathrm{C}=\mathrm{O}, 100 \mathrm{mg}, 0.439 \mathrm{mmol}, 1\right.$ equiv $)$ in $\mathrm{CD}_{2} \mathrm{Cl}_{2}(1.1 \mathrm{~mL})$ at ambient temperature in an NMR tube under an atmosphere of argon. A sharp resonance corresponding to the carbonyl of amide

\footnotetext{
${ }^{9}$ Amide $1 \mathrm{a}^{13}{ }^{13} \mathrm{C}$ was readily prepared from the commercially available benzoic acid-carboxy- ${ }^{13} \mathrm{C}\left(99 \%\right.$ atom $\left.\%{ }^{13} \mathrm{C}, \mathrm{C}_{6} \mathrm{H}_{5}{ }^{13} \mathrm{CO}_{2} \mathrm{H}\right)$.
} 
1a- ${ }^{13} \mathrm{C}$ ( $\left.\delta 166.0\right)$ was observed. Trifluoromethanesulfonic anhydride ( $80 \mu \mathrm{L}, 0.48 \mathrm{mmol}, 1.1$ equiv) was added via syringe at $23{ }^{\circ} \mathrm{C}$ and the ${ }^{13} \mathrm{C}$ NMR spectrum of the resulting mixture was immediately recorded. The starting amide was completely consumed and a new and persistent broad resonance was detected (8149.8). Addition of nitrile $2 \mathbf{a}\left(53 \mathrm{mg}, 0.48 \mathrm{mmol}, 1.1\right.$ equiv) at $23{ }^{\circ} \mathrm{C}$ and immediate ${ }^{13} \mathrm{C}$ NMR monitoring led to observation of two new sharp resonance at $\delta 166.9$ and $\delta 96.9$ along with the remaining broad resonance at $\delta 149.8$ ( 0.9:0.4,1.0, respectively). After $2 \mathrm{~h}$ heating of the mixture at $45^{\circ} \mathrm{C}$, the sample was cooled to $23{ }^{\circ} \mathrm{C}$ and the ${ }^{13} \mathrm{C}$ NMR analysis of the reaction mixture revealed a dominant new resonance at $\delta 155.1$ attributed to the desired product quinazoline 3a${ }^{13} \mathrm{C} \cdot \mathrm{HOTf}$ and disappearance of the broad resonance at $\delta 149.8$. The resonances at $\delta 166.9$ and $\delta 96.9$ were weak $(\sim 5 \%)$ but remained detectable. The assignment of the resonance at $\delta 155.1$ to $\mathbf{3 a}$ ${ }^{13} \mathrm{C} \cdot$ HOTf was confirmed independently by protonation of a sample of product $3 \mathbf{a}^{13} \mathrm{C}$ with $\mathrm{TfOH}(1$ equiv) in $\mathrm{CD}_{2} \mathrm{Cl}_{2}$. The NMR tube was placed in a $45{ }^{\circ} \mathrm{C}$ oil bath and maintained at that temperature for an additional $14 \mathrm{~h}$. At this time, the only dominant $13 \mathrm{C}$ resonance was that attributed to the desired product quinazoline $\mathbf{3 a}-{ }^{13} \mathrm{C} \cdot \mathrm{HOTf}(\delta 155.1)$. An aqueous sodium hydroxide solution $(1 \mathrm{~mL}$, $1 \mathrm{~N})$ was introduced to neutralize the trifluoromethanesulfonate salts. Dichloromethane $(5 \mathrm{~mL})$ was added to dilute the mixture and the layers were separated. The organic layer was washed with brine ( 2 mL30, was dried over anhydrous sodium sulfate, and was filtered. The volatiles were removed under reduced pressure and the residue was purified by flash column chromatography (eluent: 10\% EtOAc in hexanes; $\mathrm{SiO}_{2}: 15 \times 1.5 \mathrm{~cm}$ ) on neutralized silica gel to give the isotopically enriched quinazoline product $3 \mathbf{a}^{-13} \mathrm{C}$ as a white solid (79 $\left.\mathrm{mg}, 56 \%\right)$.

The ${ }^{1} \mathrm{H},{ }^{13} \mathrm{C}$, and ${ }^{19} \mathrm{~F}$ NMR and the in situ React-IR experiments described above are consistent with the activation of the starting amide to a reactive amidinium intermediate such as $\mathbf{5}$ that is likely to be in equilibrium with the corresponding triflate adduct S9. ${ }^{10}$ Nucleophilic displacement of the 2-chloropyridine could result in formation of the adduct $\mathbf{6}$ followed by cycloisomerization to $3 .^{11}$ The conversion of $\mathbf{6}$ to $\mathbf{3}$ may be facilitated by net addition of 2chloropyridinium triflate across the nitrilium ion. The product 3 serves as the second equivalent of base under the reaction conditions as described above. Rapid exchange of the trifluoromethane sulfonates is likely responsible for observation of a single broad ${ }^{19} \mathrm{~F}$ NMR resonance for the activated intermediate.

Scheme S1.

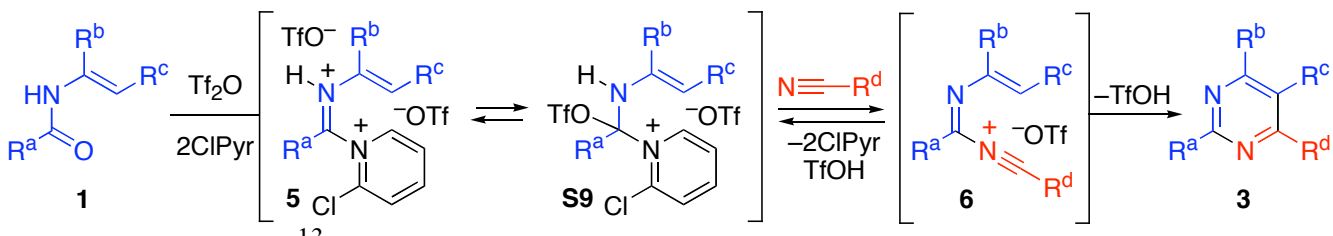

While the broad ${ }^{13} \mathrm{C}$-resonance at $\delta 149.8$ described above is likely a time averaged value for the activated forms of the amide, the observed transient resonances at $\delta 166.9$ and $\delta 96.9$ may be related to derivatives of $\mathbf{5}$ and $\mathbf{S 9}$, respectively. ${ }^{12,13}$

\footnotetext{
${ }^{10}$ a) The presence of a persistent nitrilium intermediate was not observed, but its transient formation cannot be ruled out. Please see Booth, B. L.; Jibodu, K. O.; Proença, M. F. Chem. Commun. 1980, 1151. b) For ${ }^{19}$ F NMR detection of a related anomeric trifluoromethanesulfonate adduct, see Rencurosi, A.; Lay, L.; Russo, G.; Caneva, E.; Poletti, L. Carbohydrate Research $2006,341,903$. ${ }^{11}$ The conversion of $\mathbf{6}$ to $\mathbf{3}$ may be facilitated by net addition of 2-chloropyridinium triflate across the nitrilium ion.

${ }^{12}$ For spectroscopic study of related structures, see: a) Coustartd, J.-M. Tetrahedron 1999, 55, 5809. b) Charette, A. B.; Mathieu, S.; Martel, J. Org. Lett. 2005, 7, 5401. c) Charette, A. B.; Grenon, M. Can. J. Chem. 2001, 79, 1694.

${ }^{13}$ Unlike the amidinium derivatives of pyridine (see references $12 \mathrm{~b}$ and $12 \mathrm{c}$ ), we expect those derived from 2-chloropyridine to be far more electrophilic, allowing the formation of adducts and disfavoring a persistent doubly cationic amidinium ion. An alternative to $\mathbf{5}$ may be the hydrogen bonded complex of trifluoromethanesulfonic acid as opposed to the fully protonated form.
} 


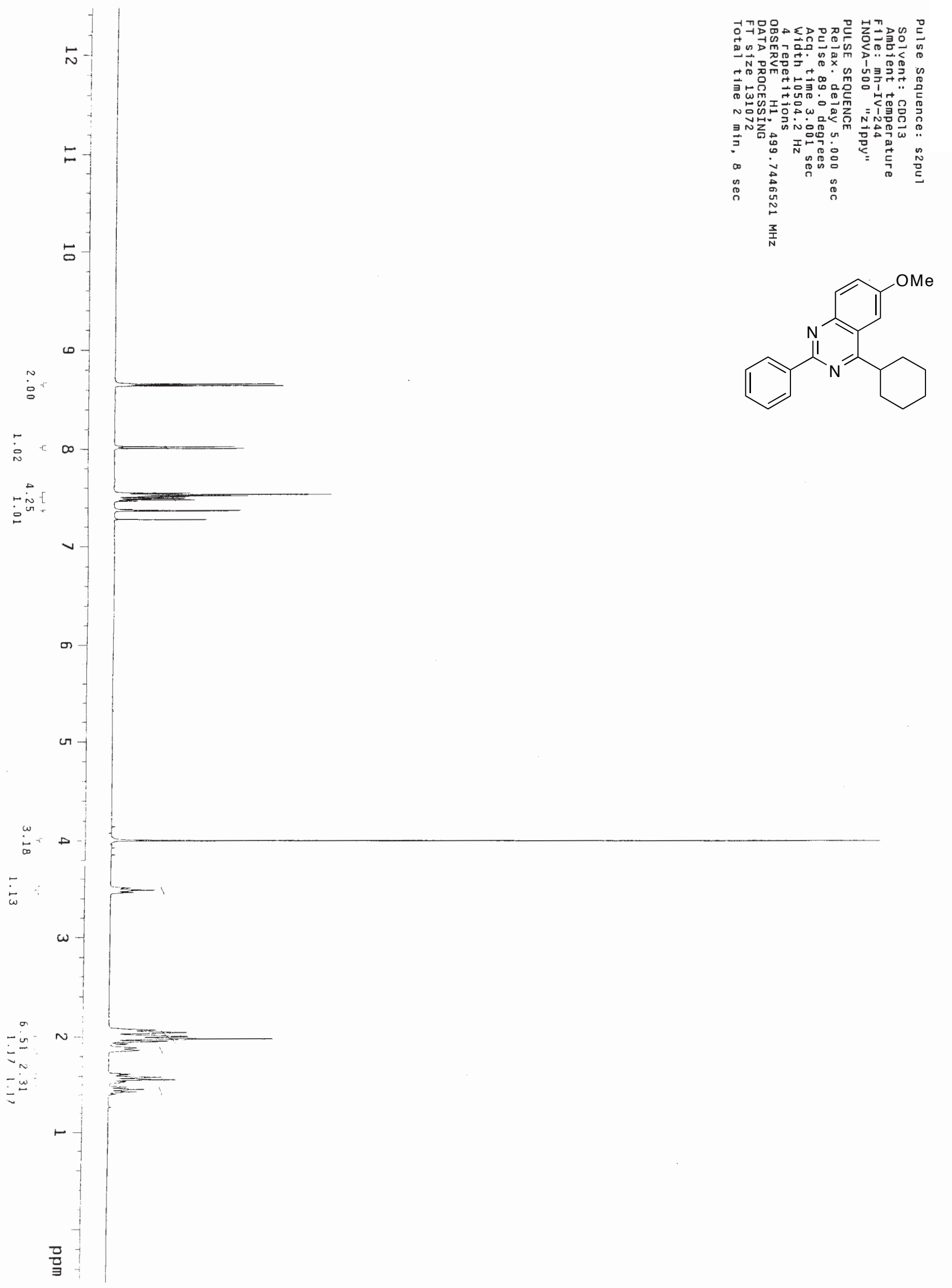




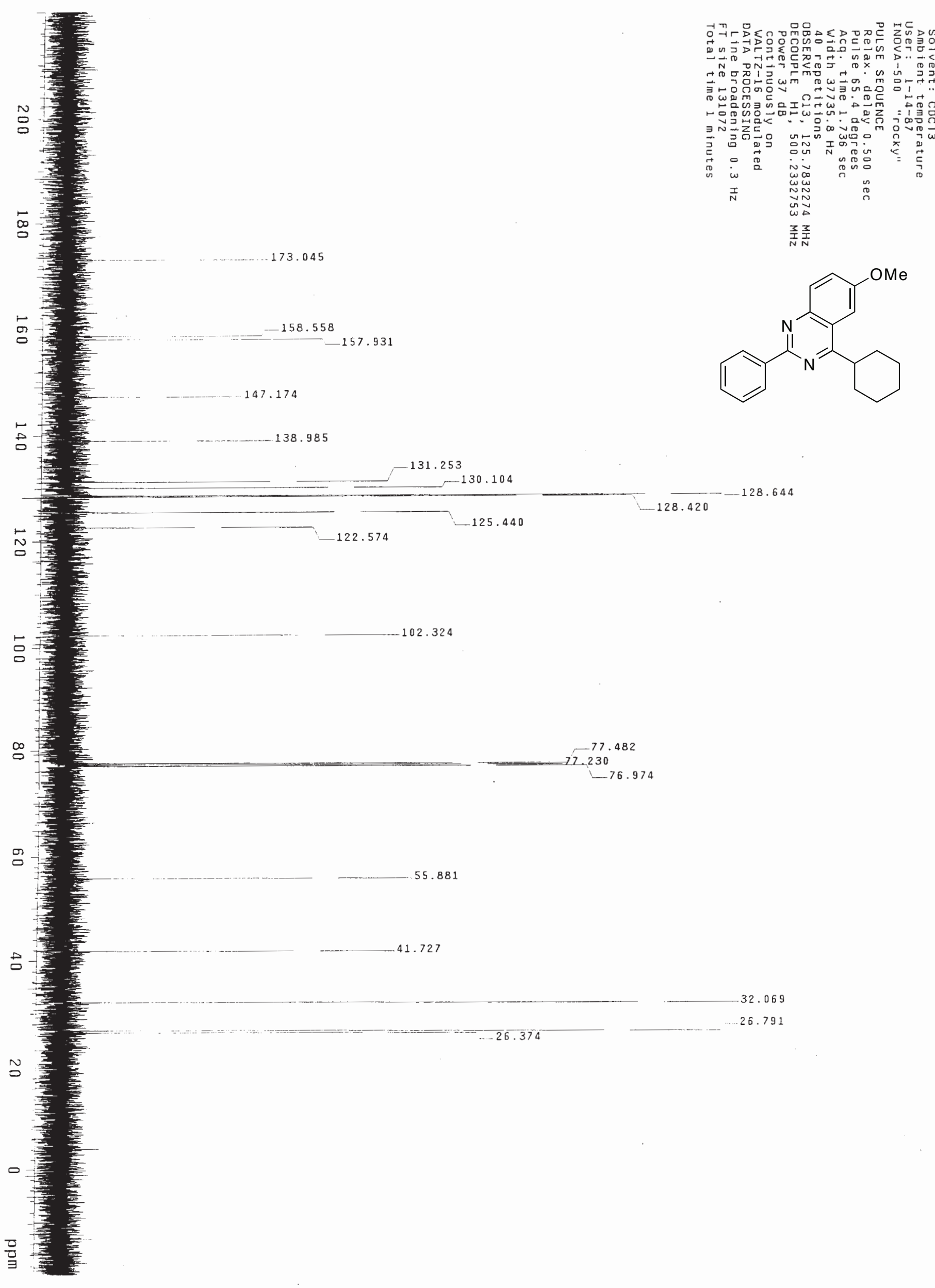




\section{S33/S80}

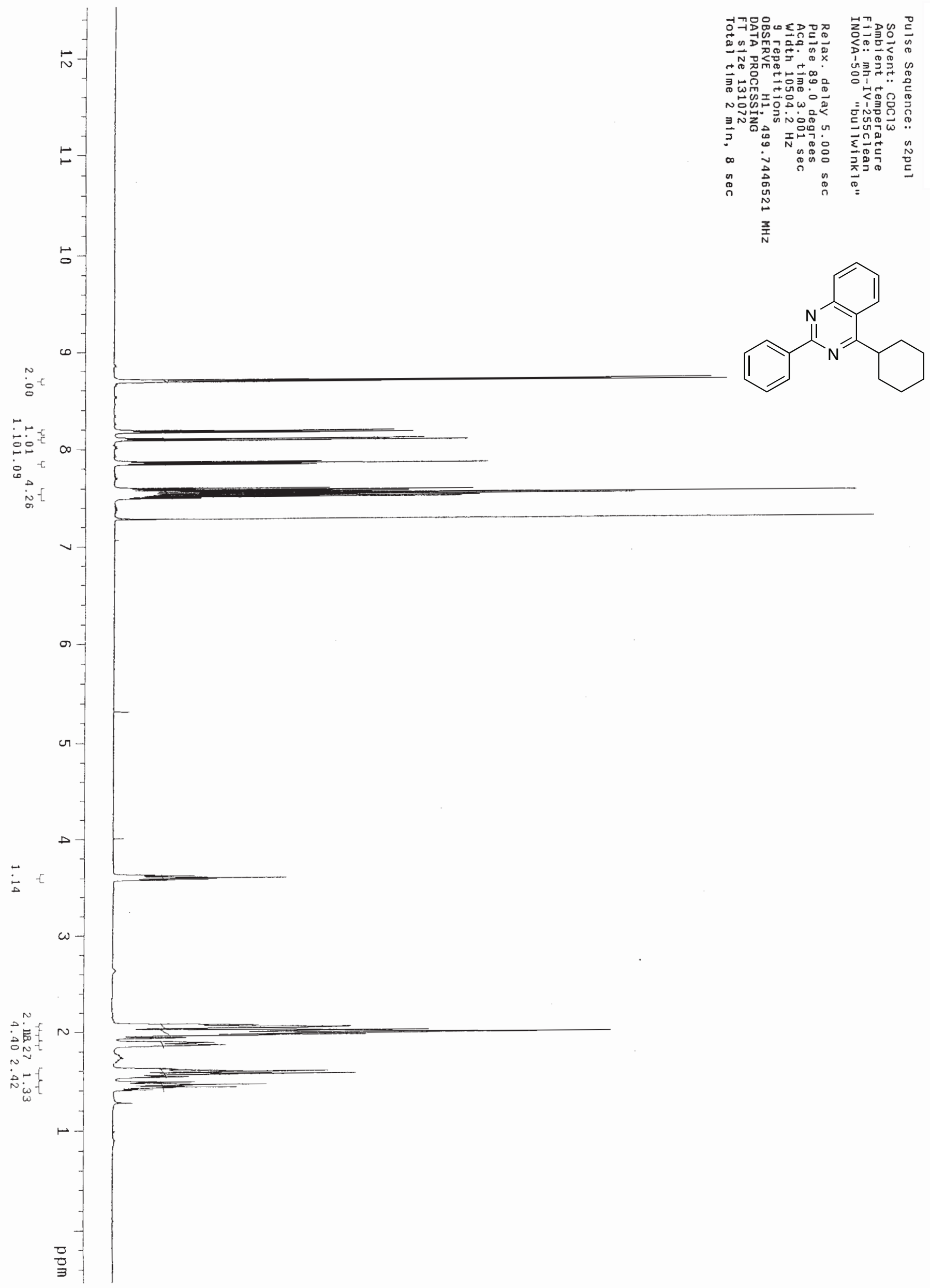




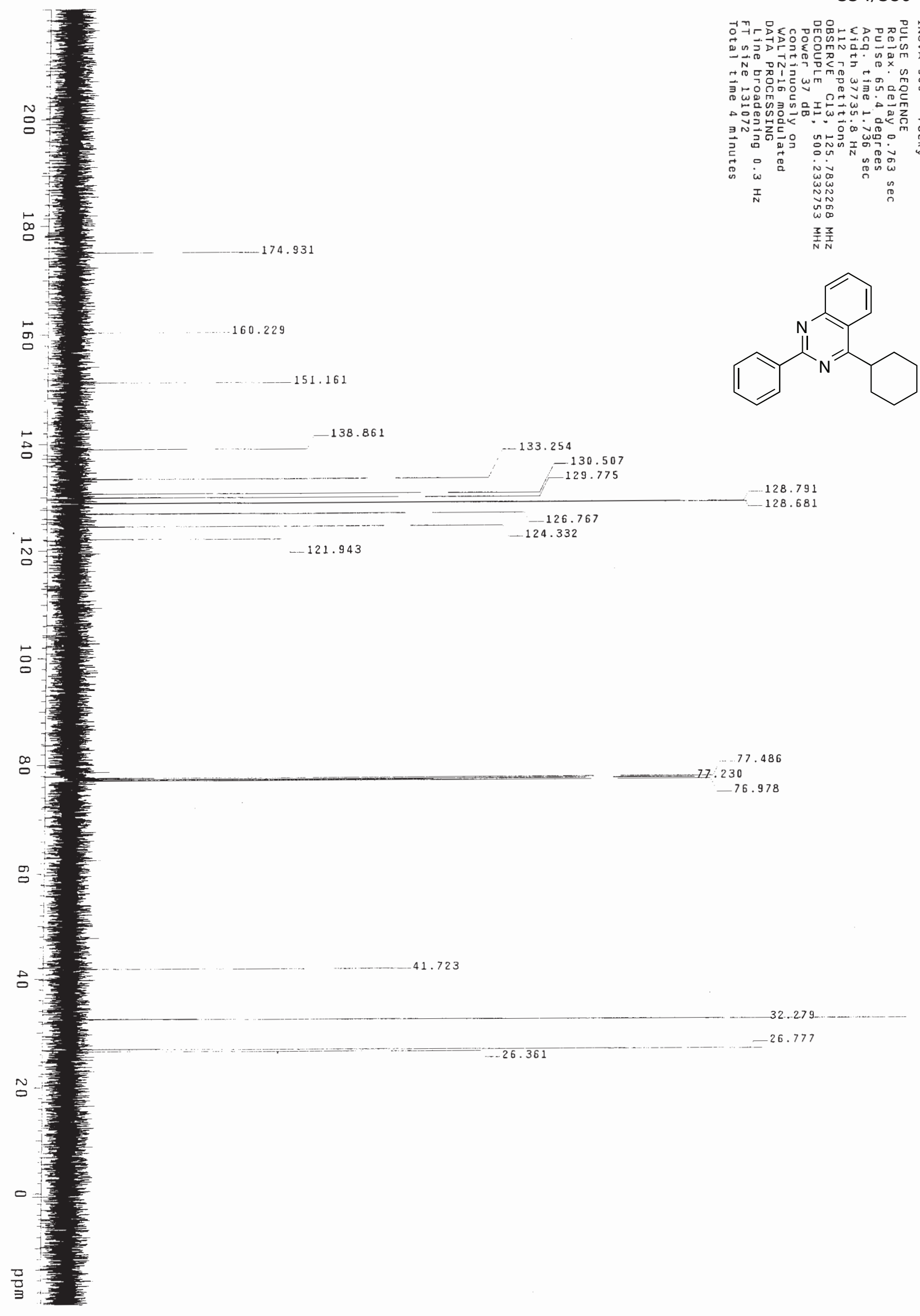




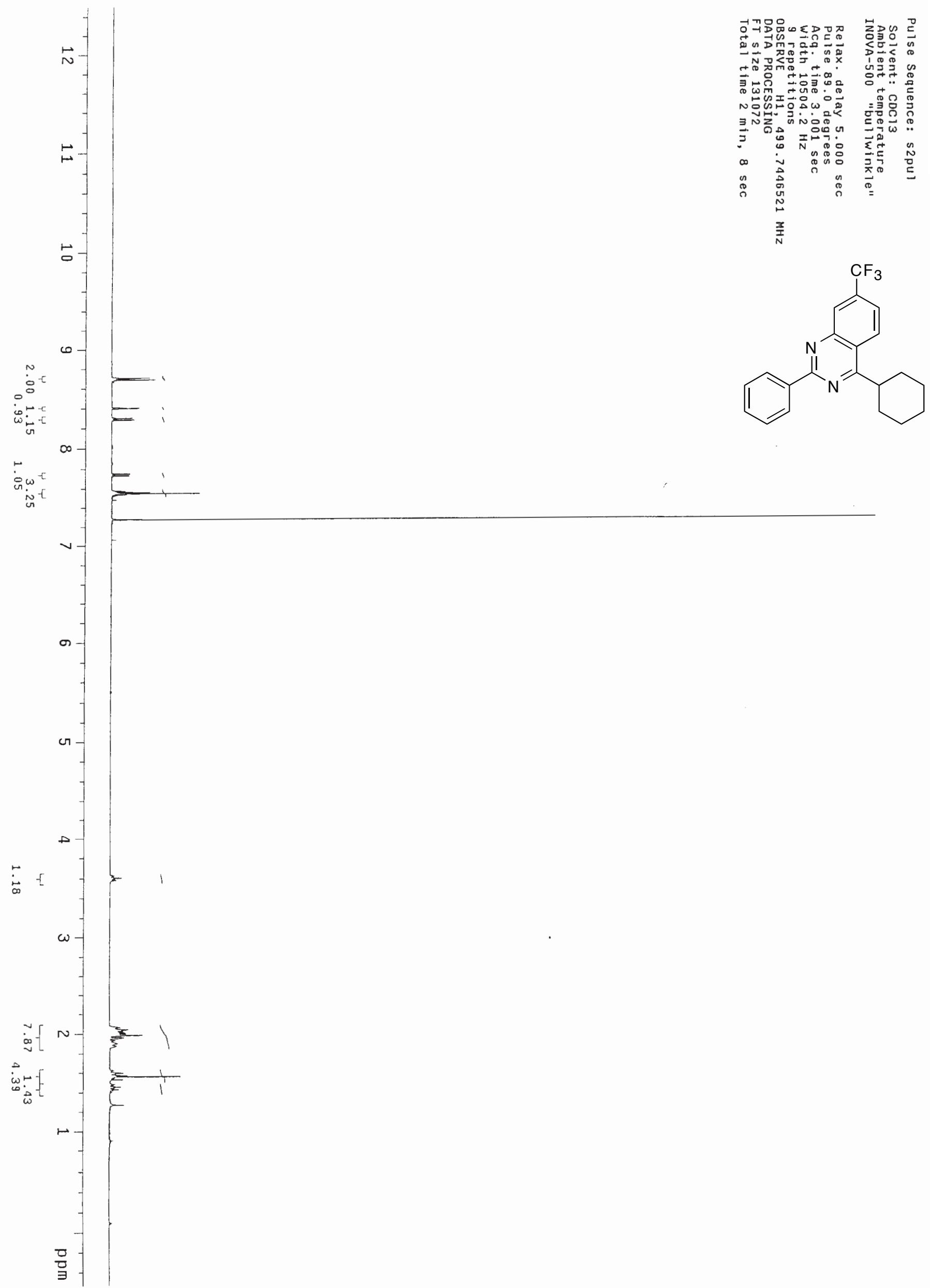




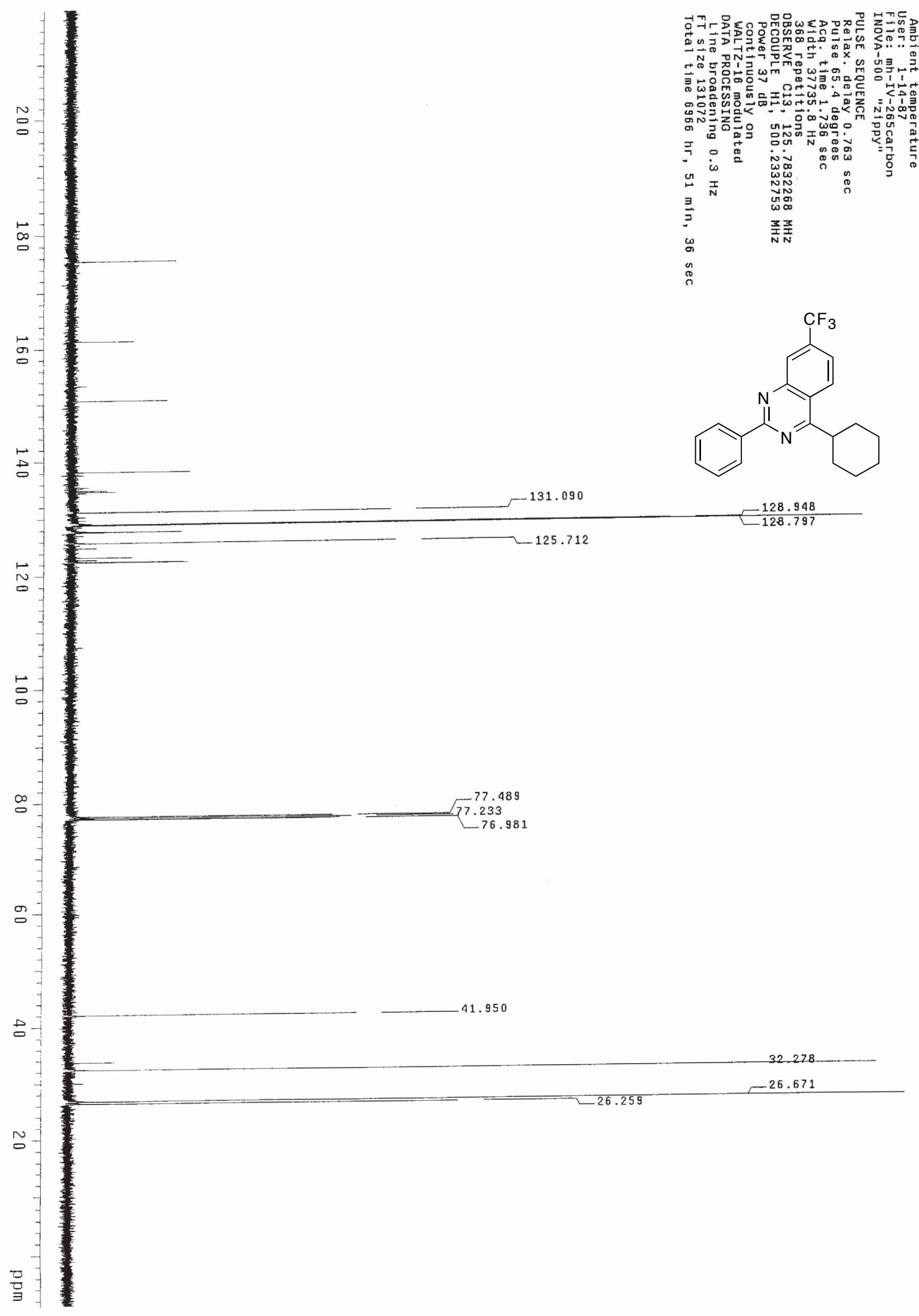




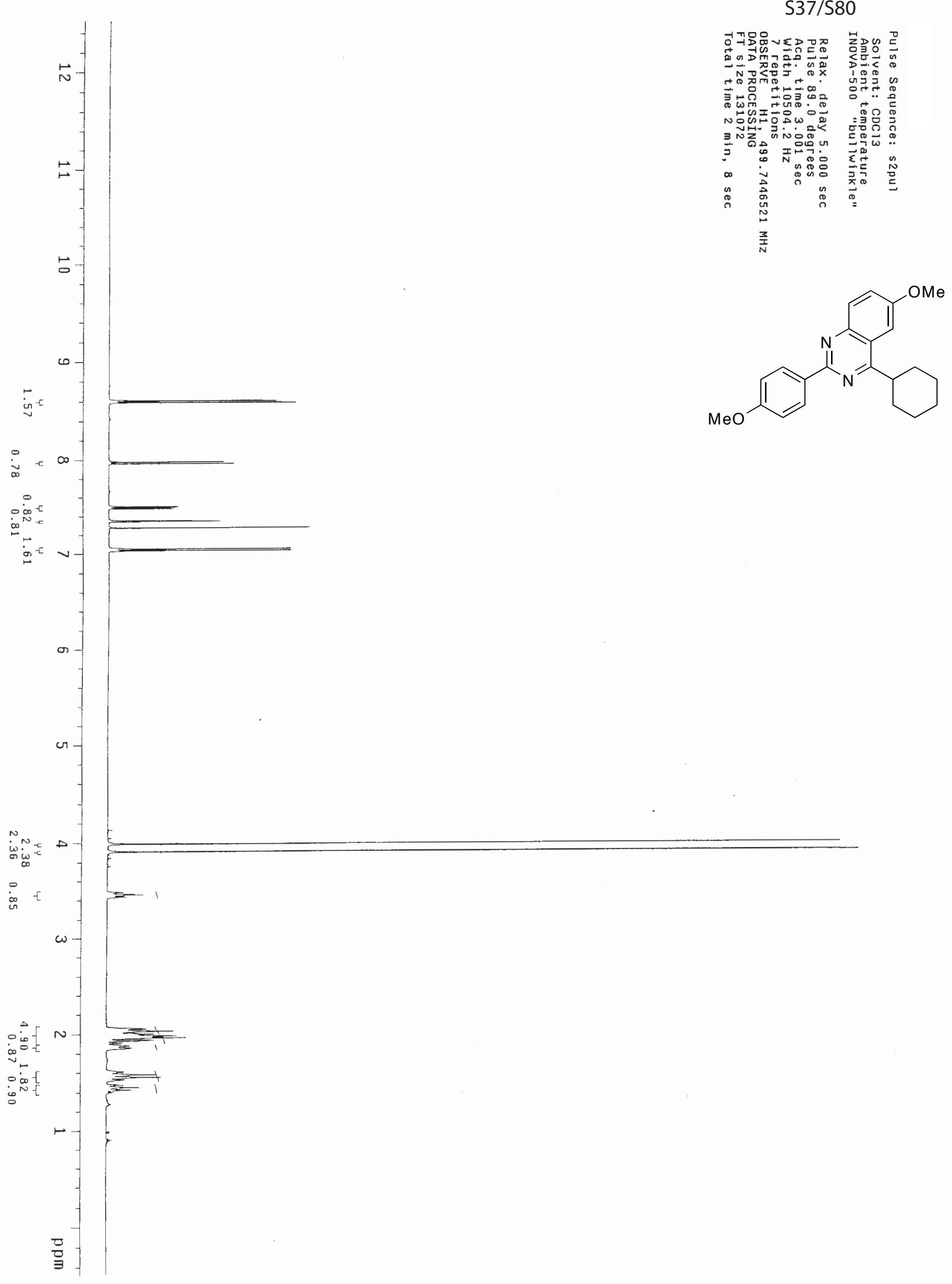




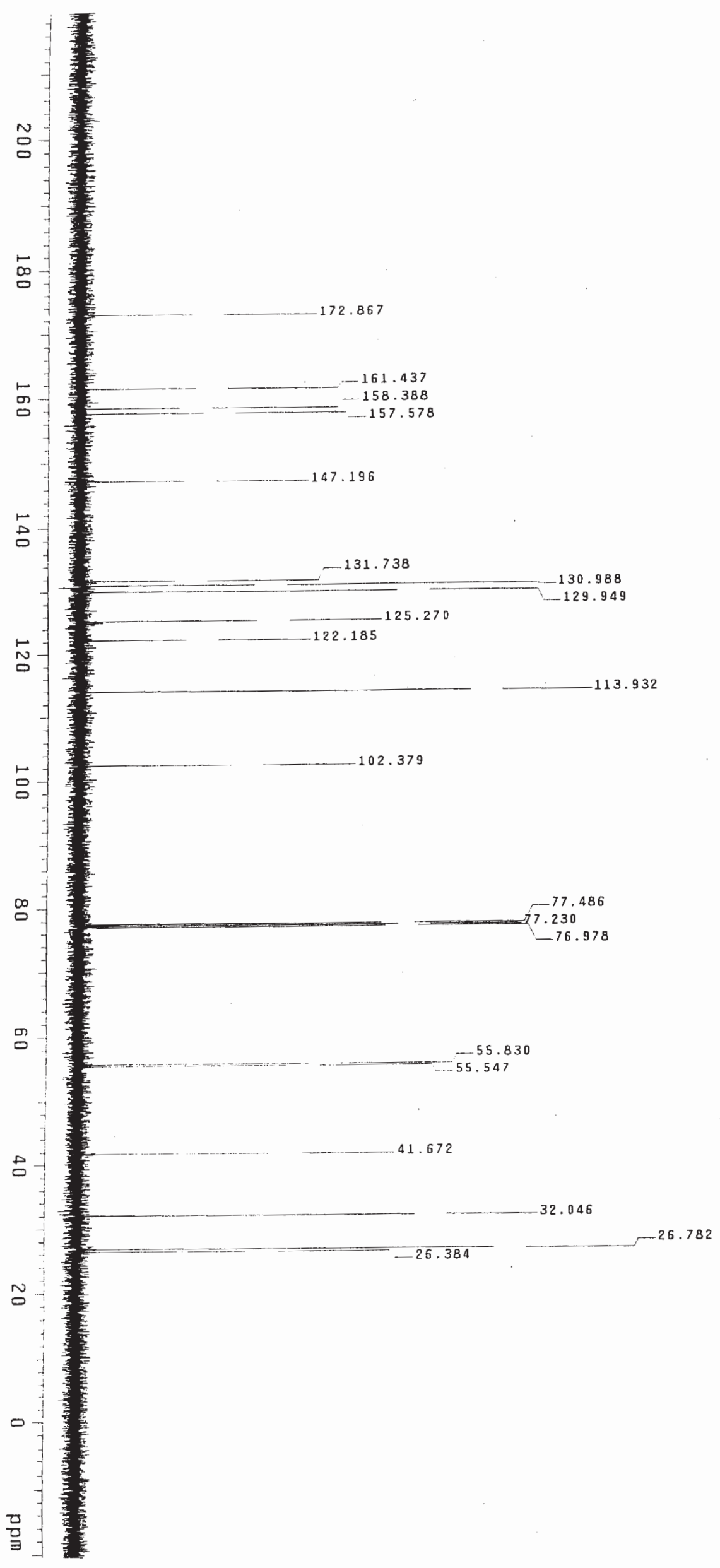

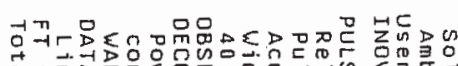

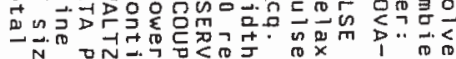

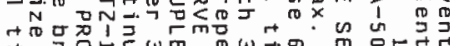

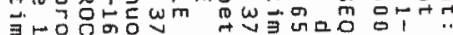

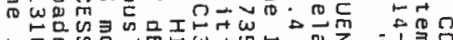

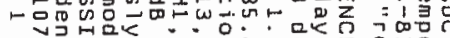
BNJZE उ

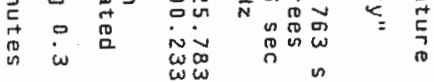

N in

조N조N<smiles>COc1ccc(-c2nc(C3CCCCC3)c3cc(OC)ccc3n2)cc1</smiles> 


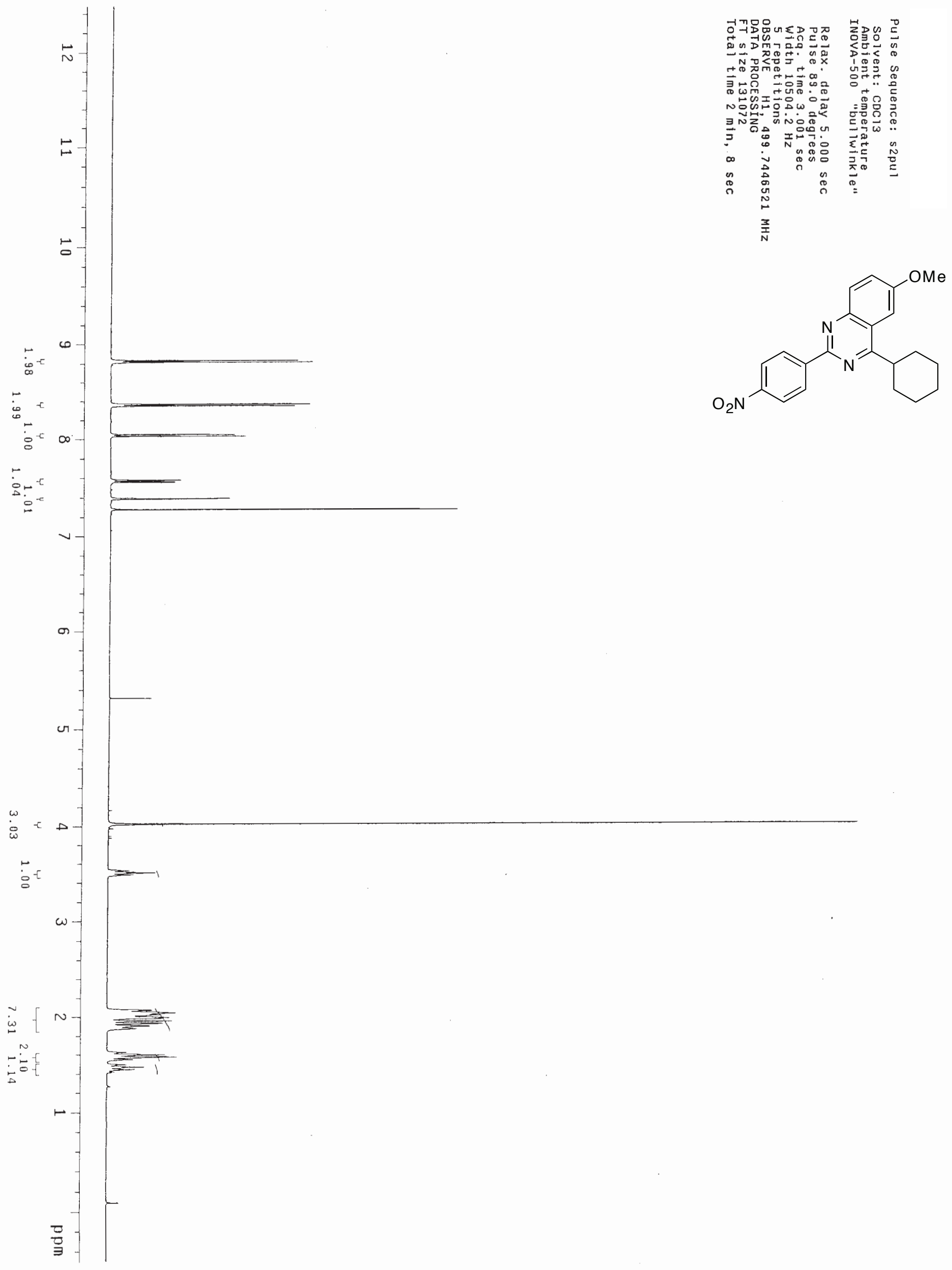




\section{$S 40 / 580$}

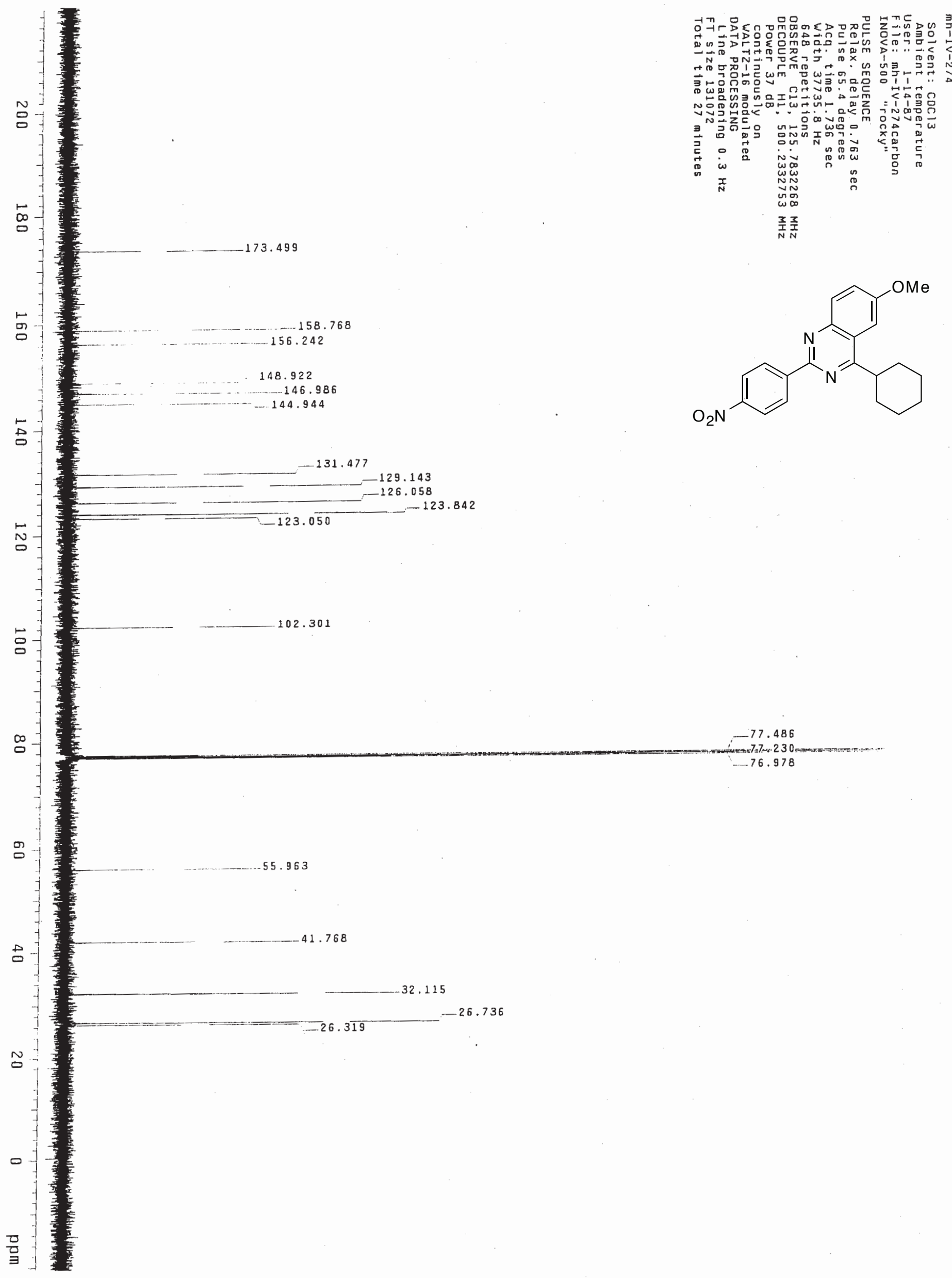




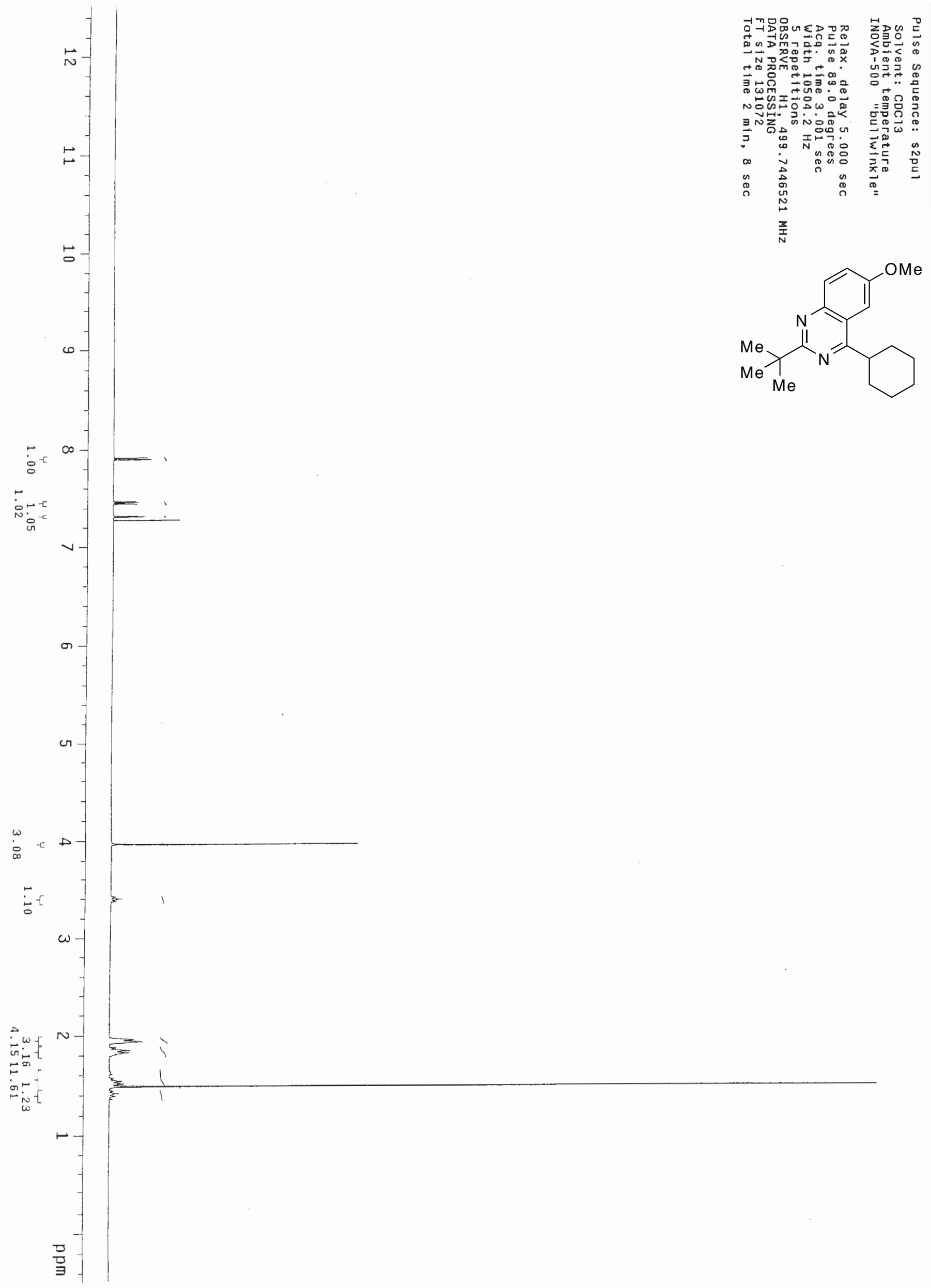




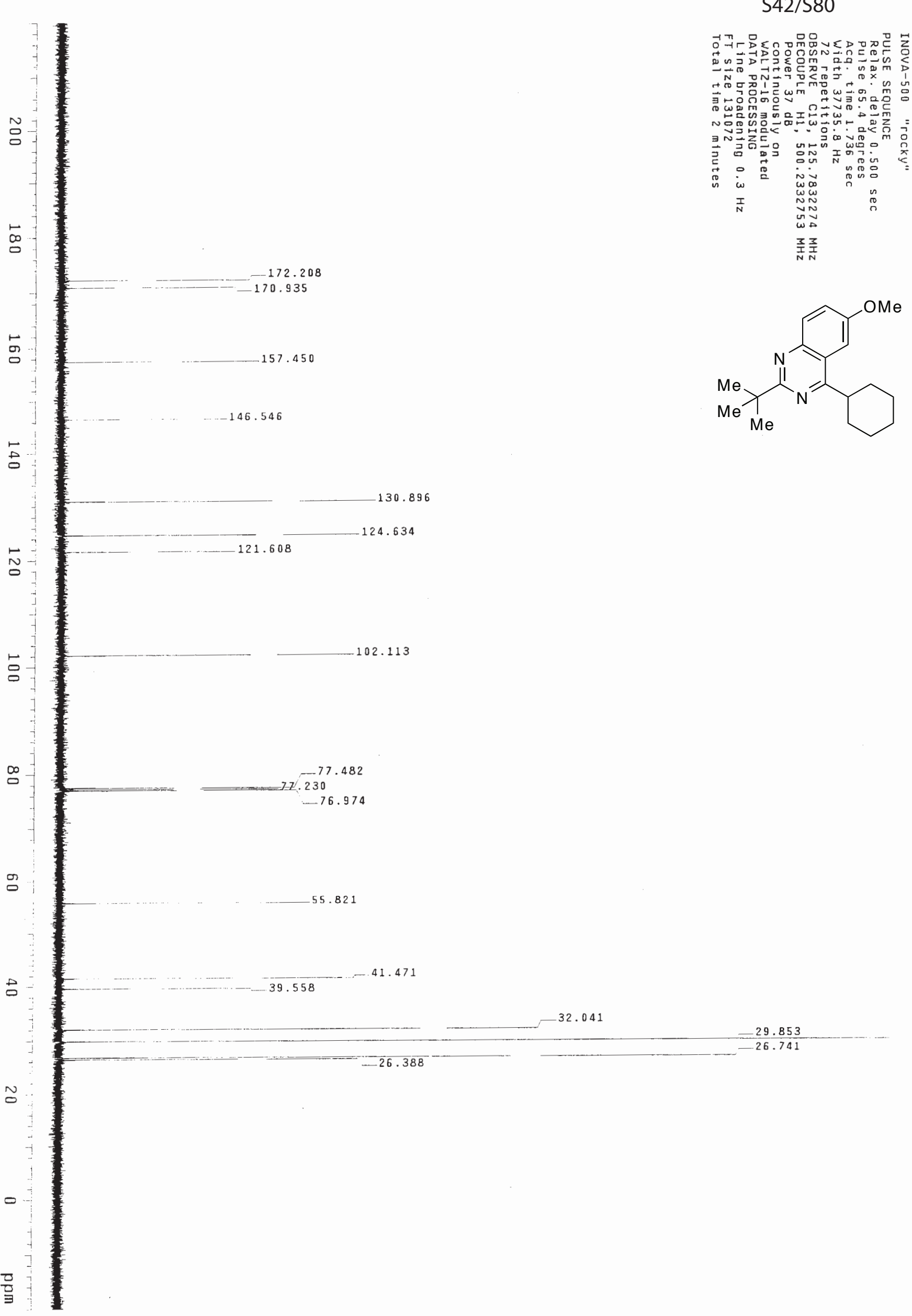


S43/S80

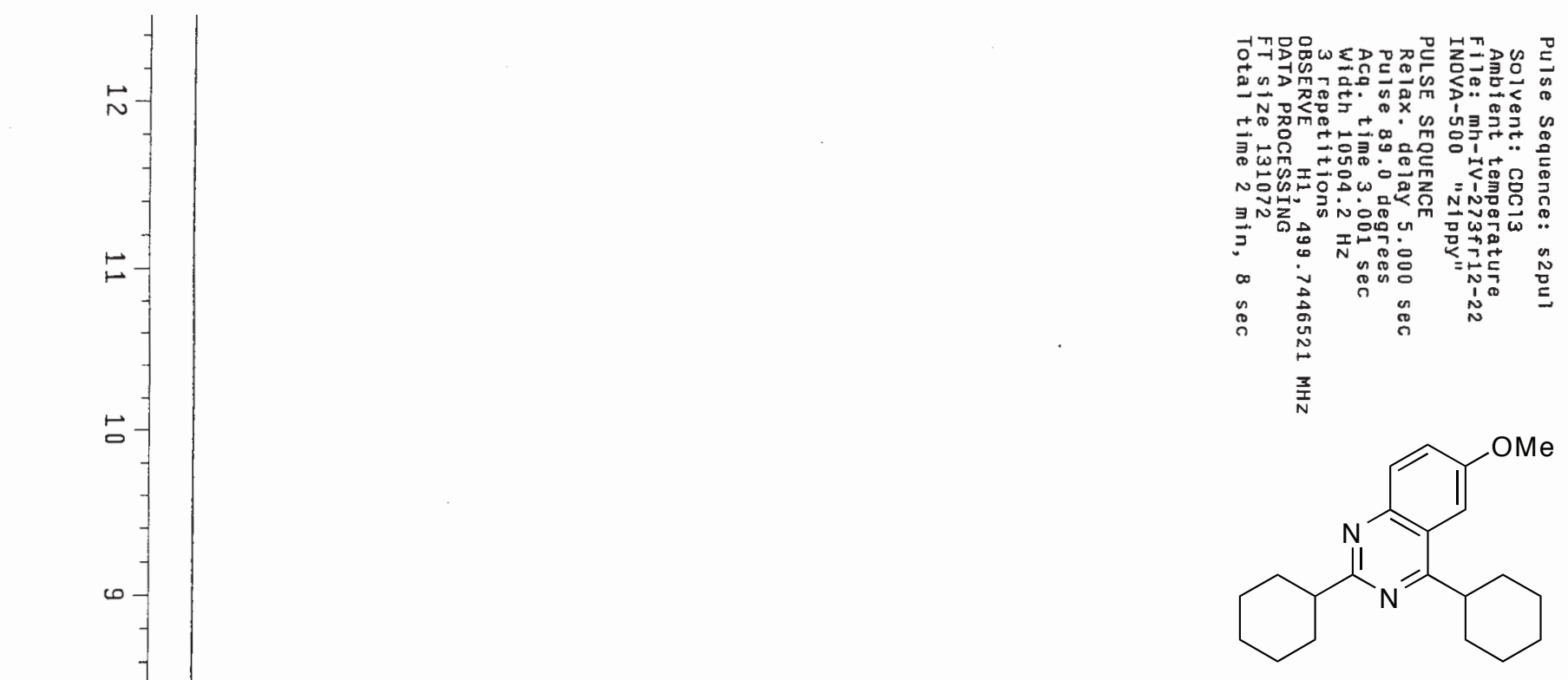




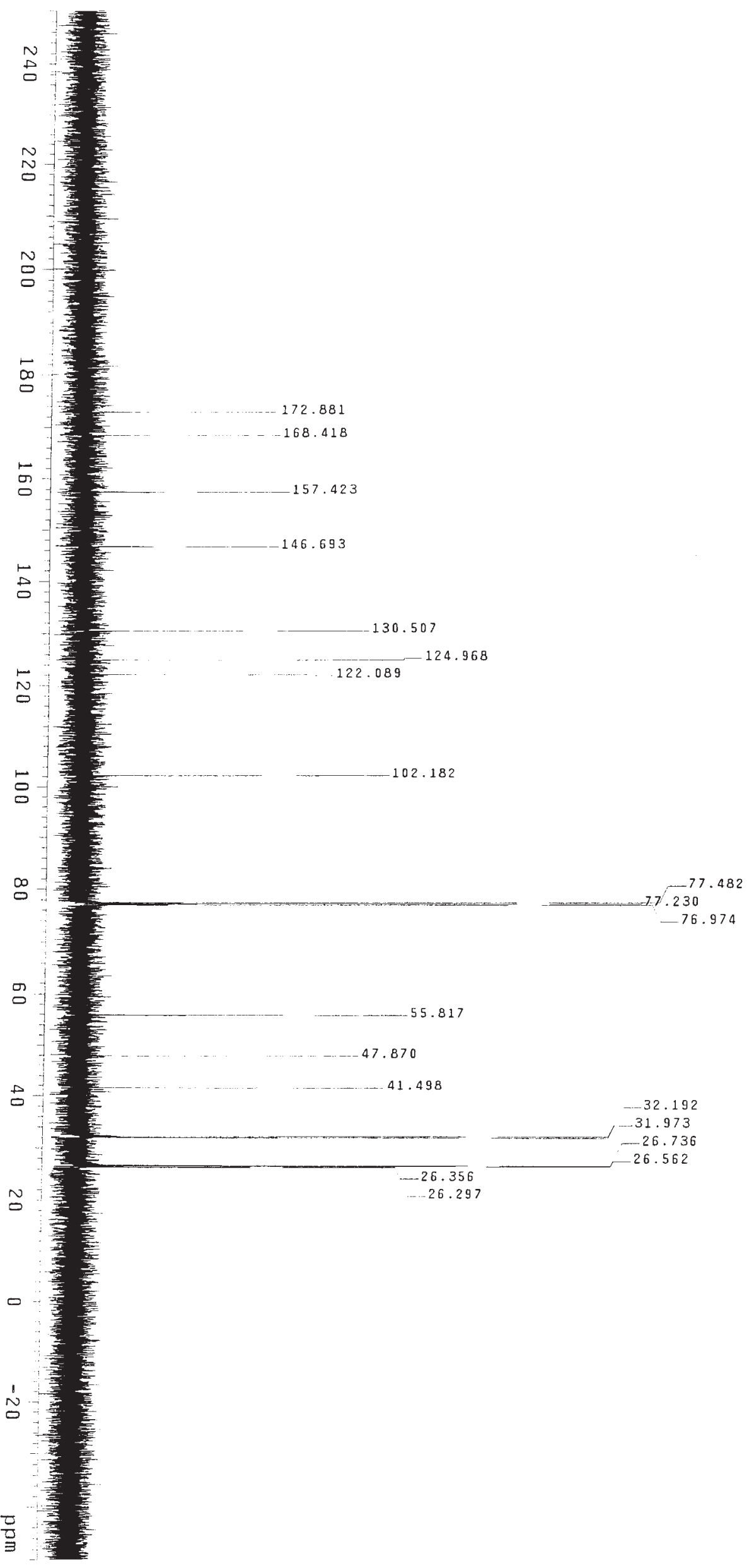<smiles>COc1ccc2nc(C3CCCCC3)nc(C3CCCCC3)c2c1</smiles> 


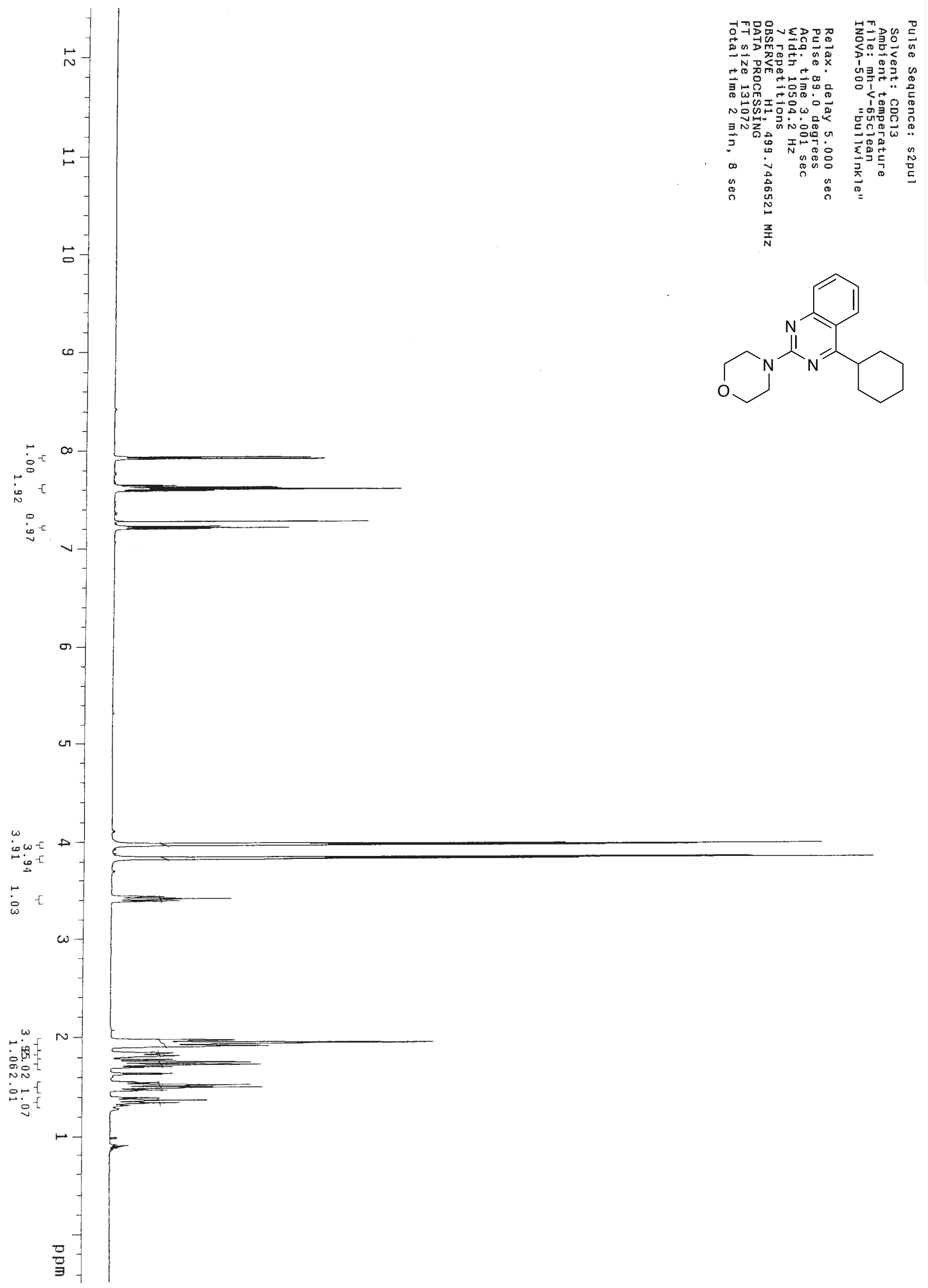




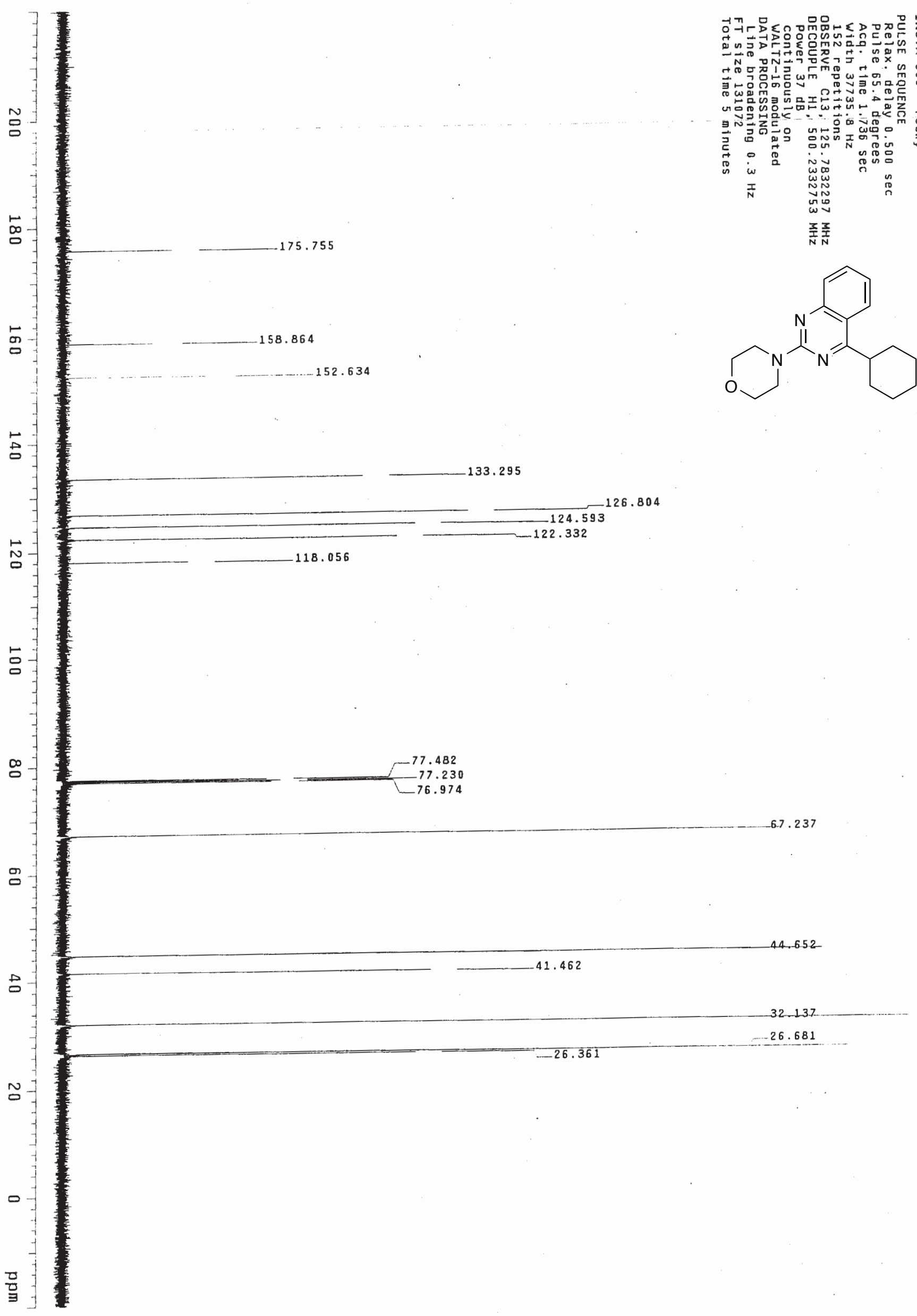




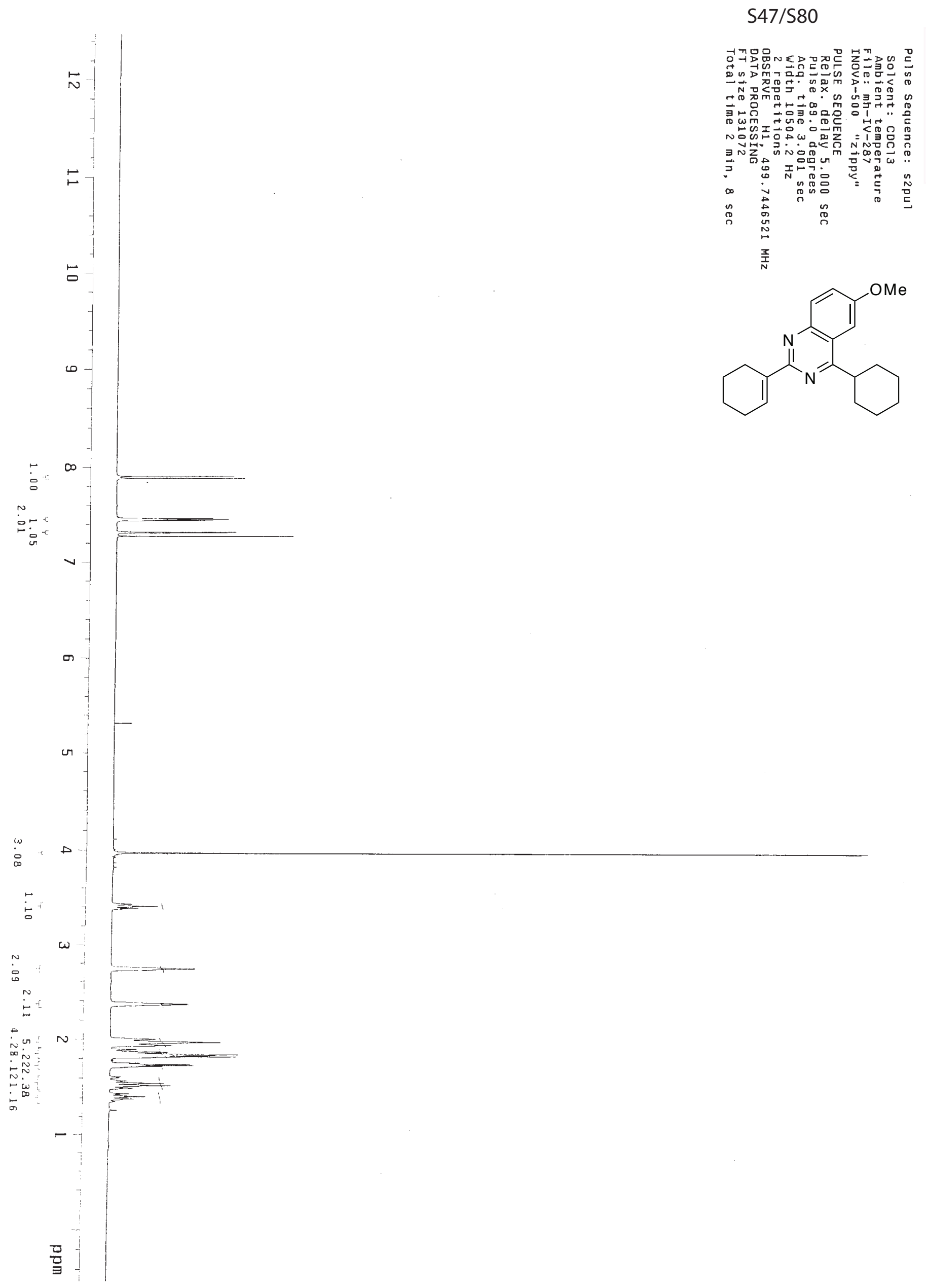




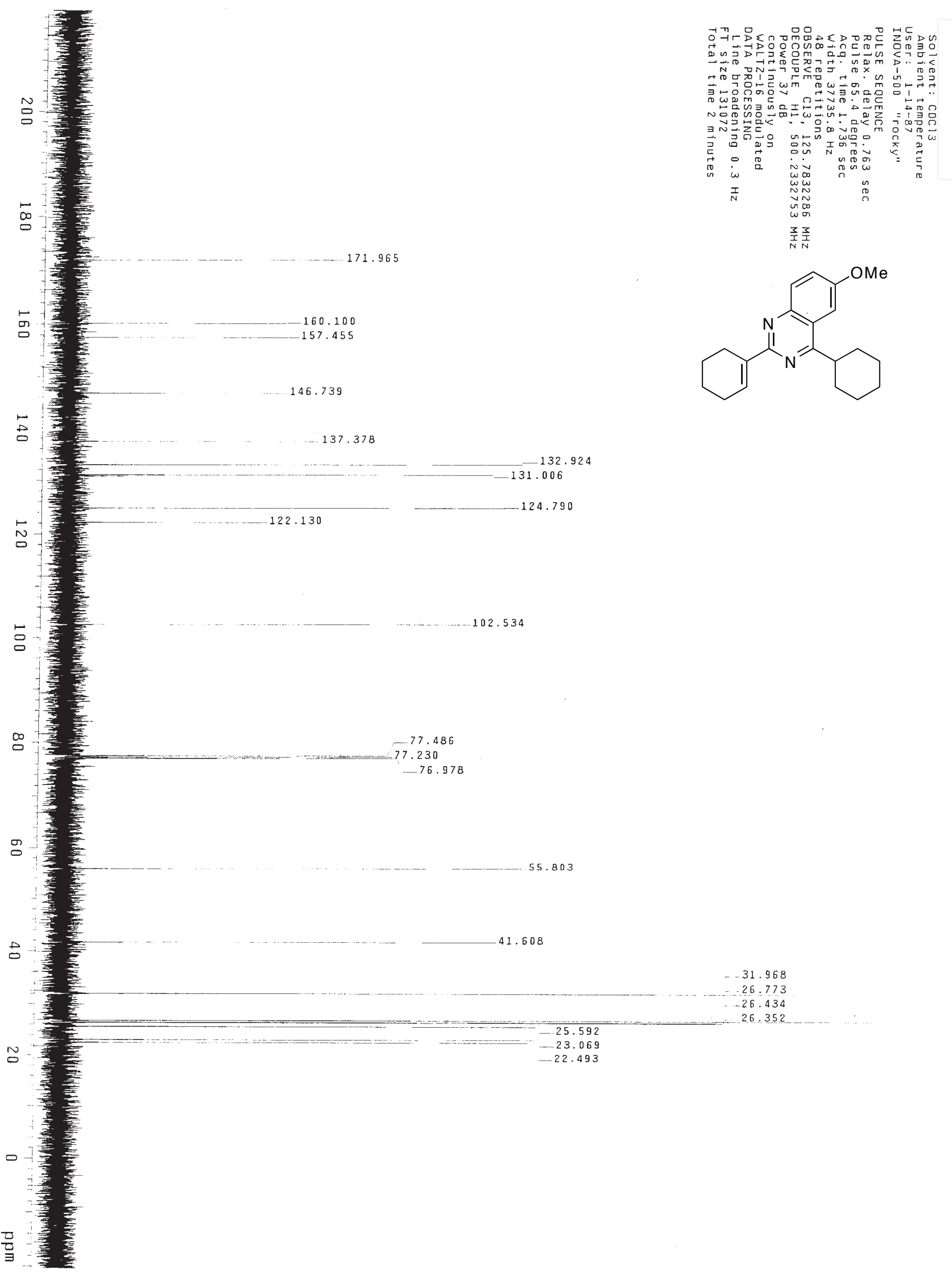




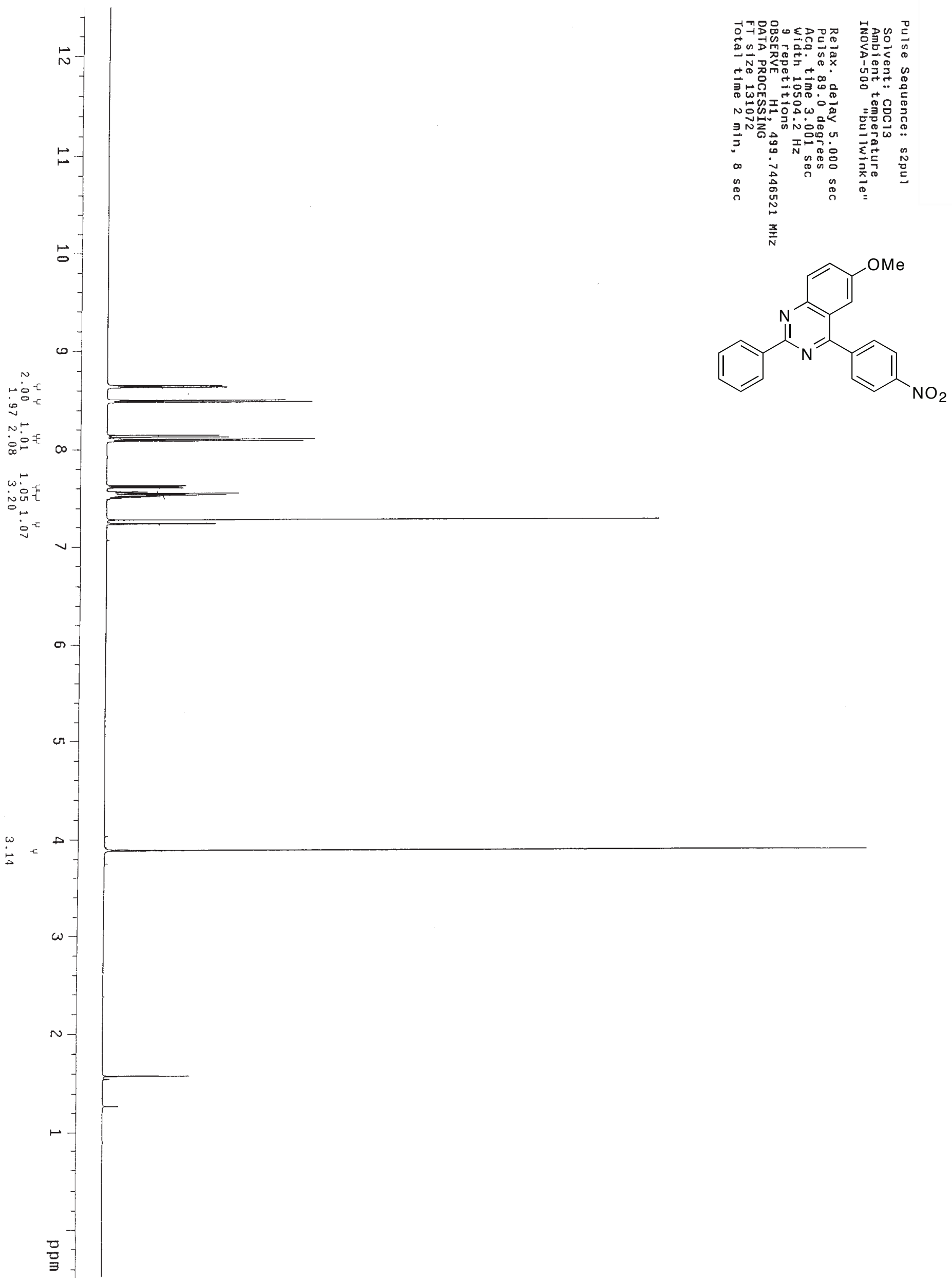




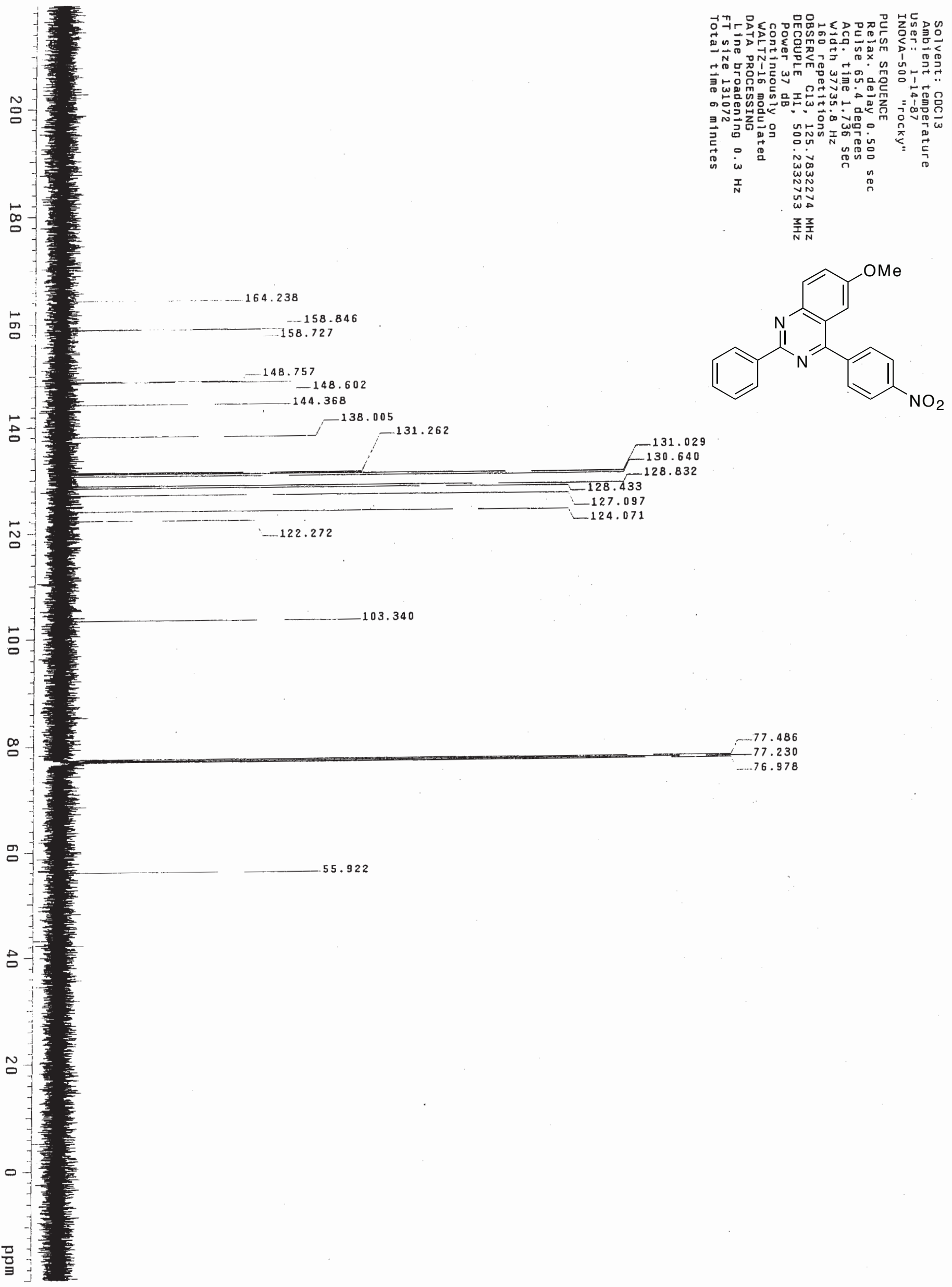




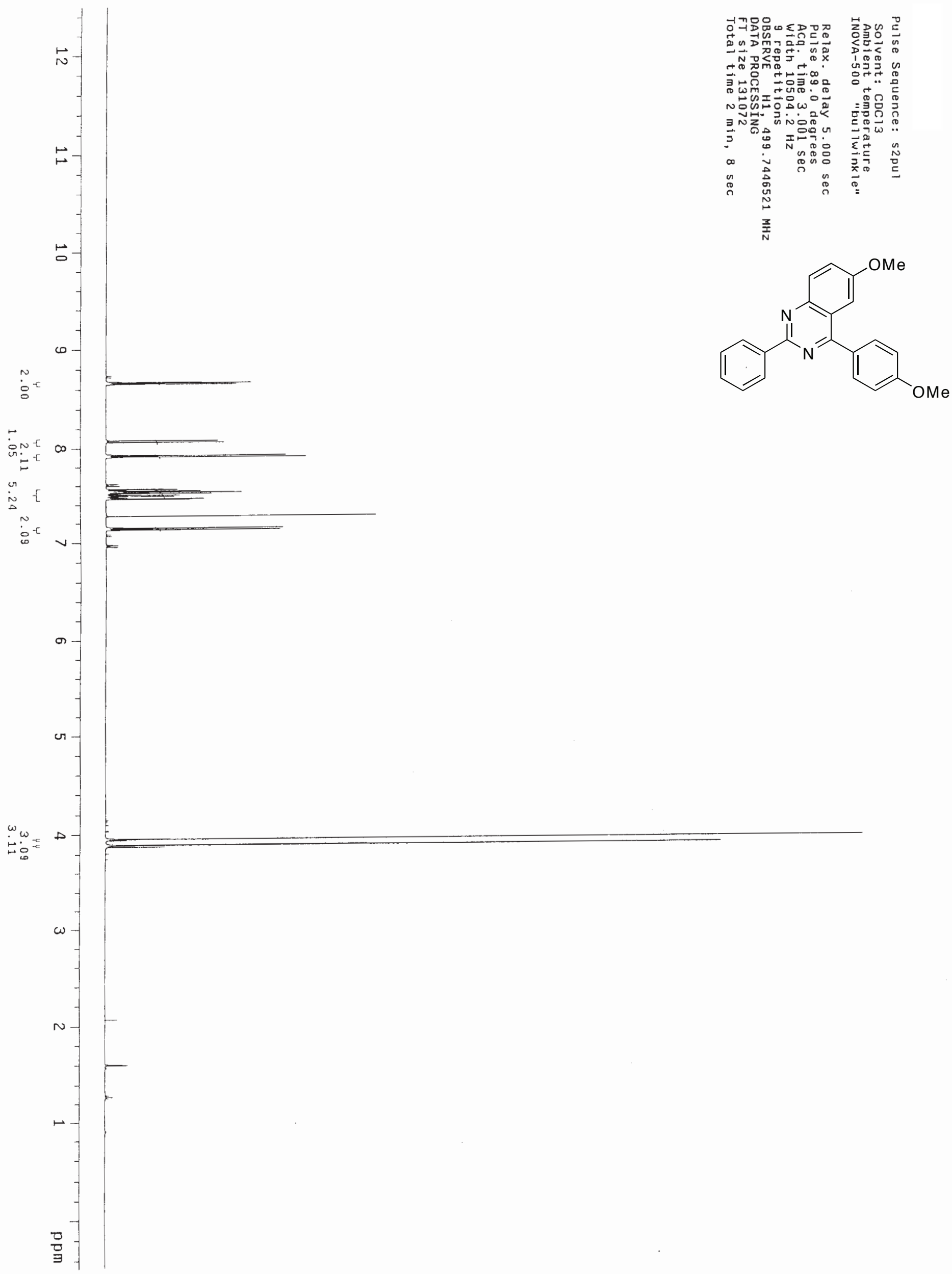




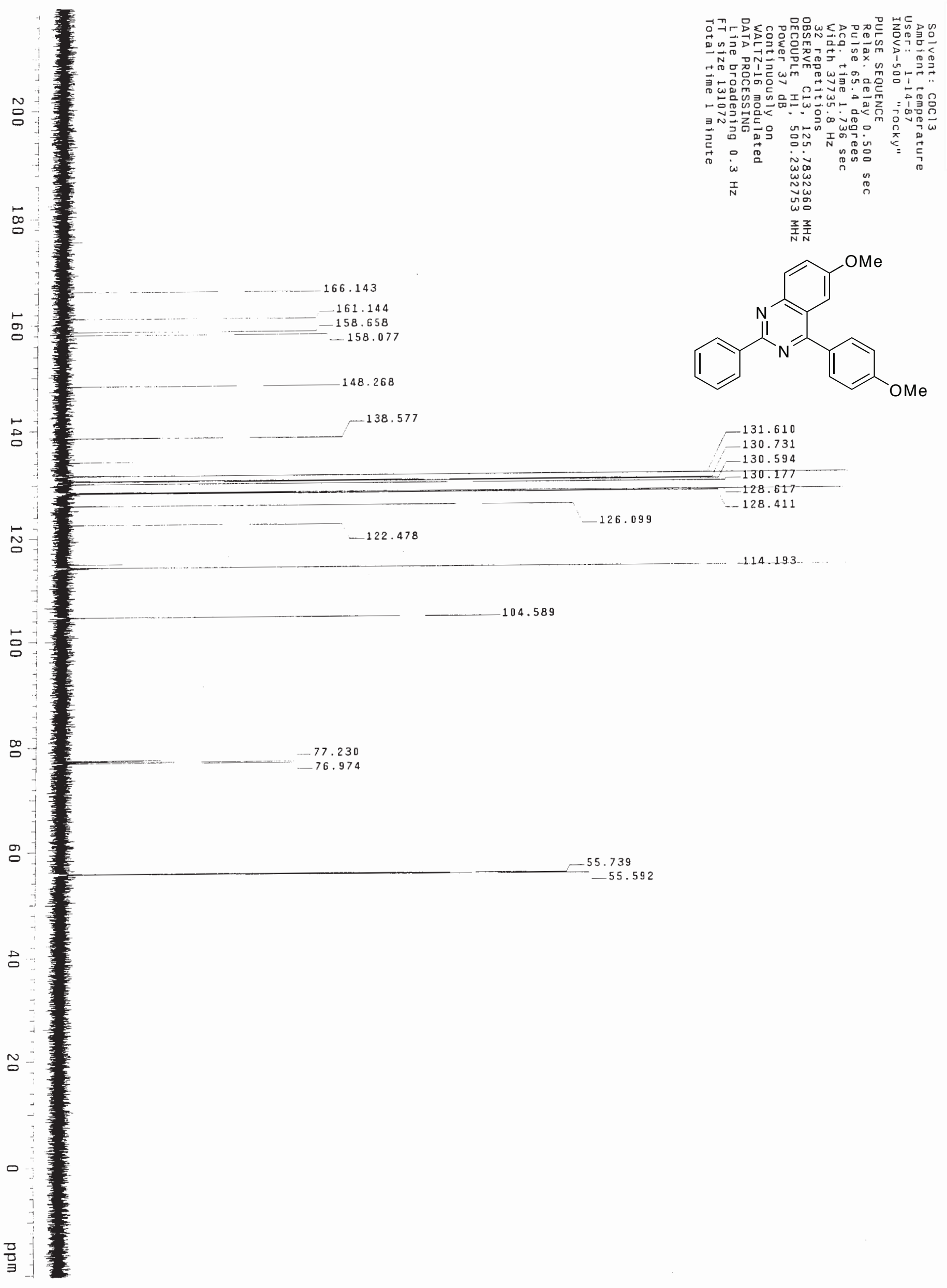



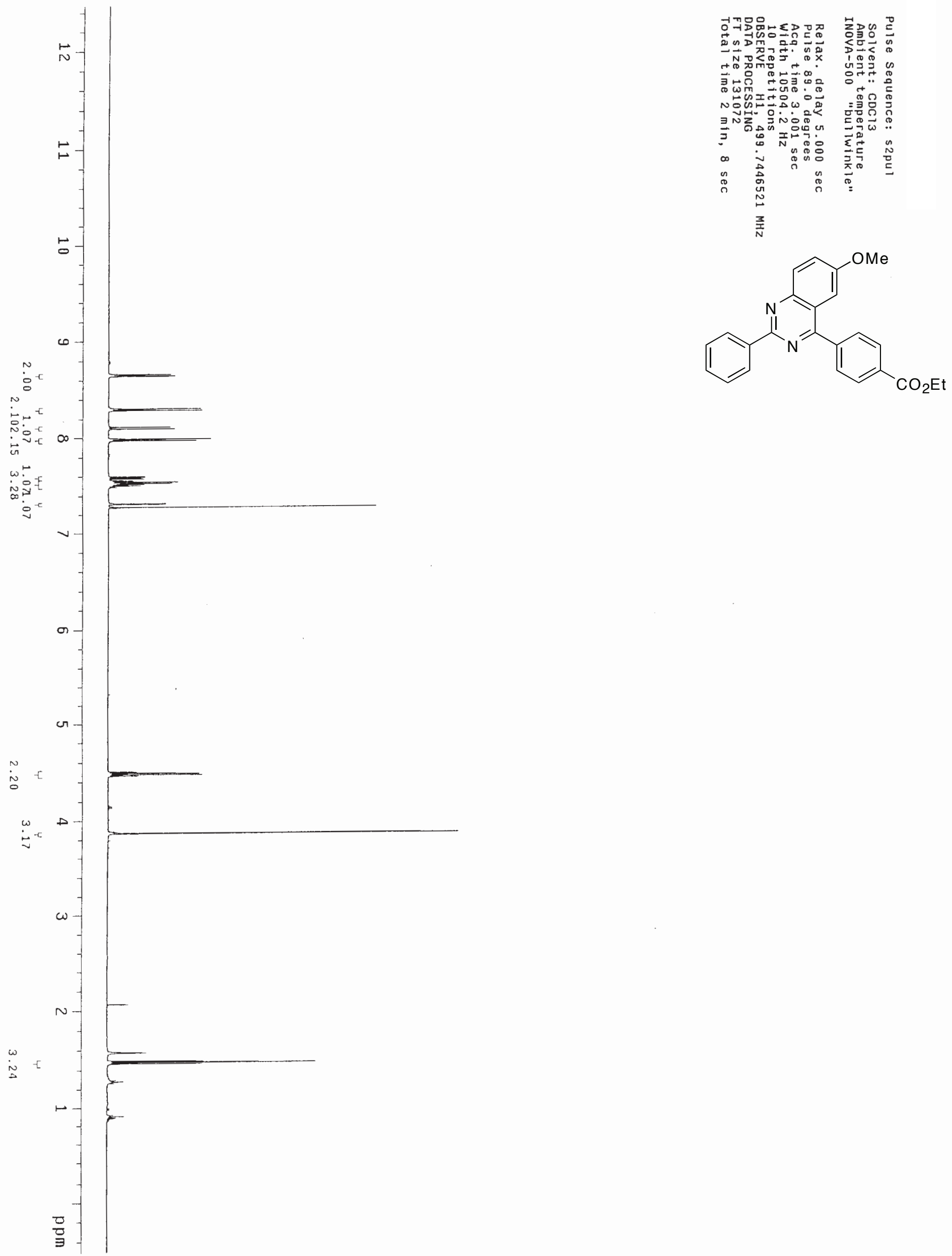


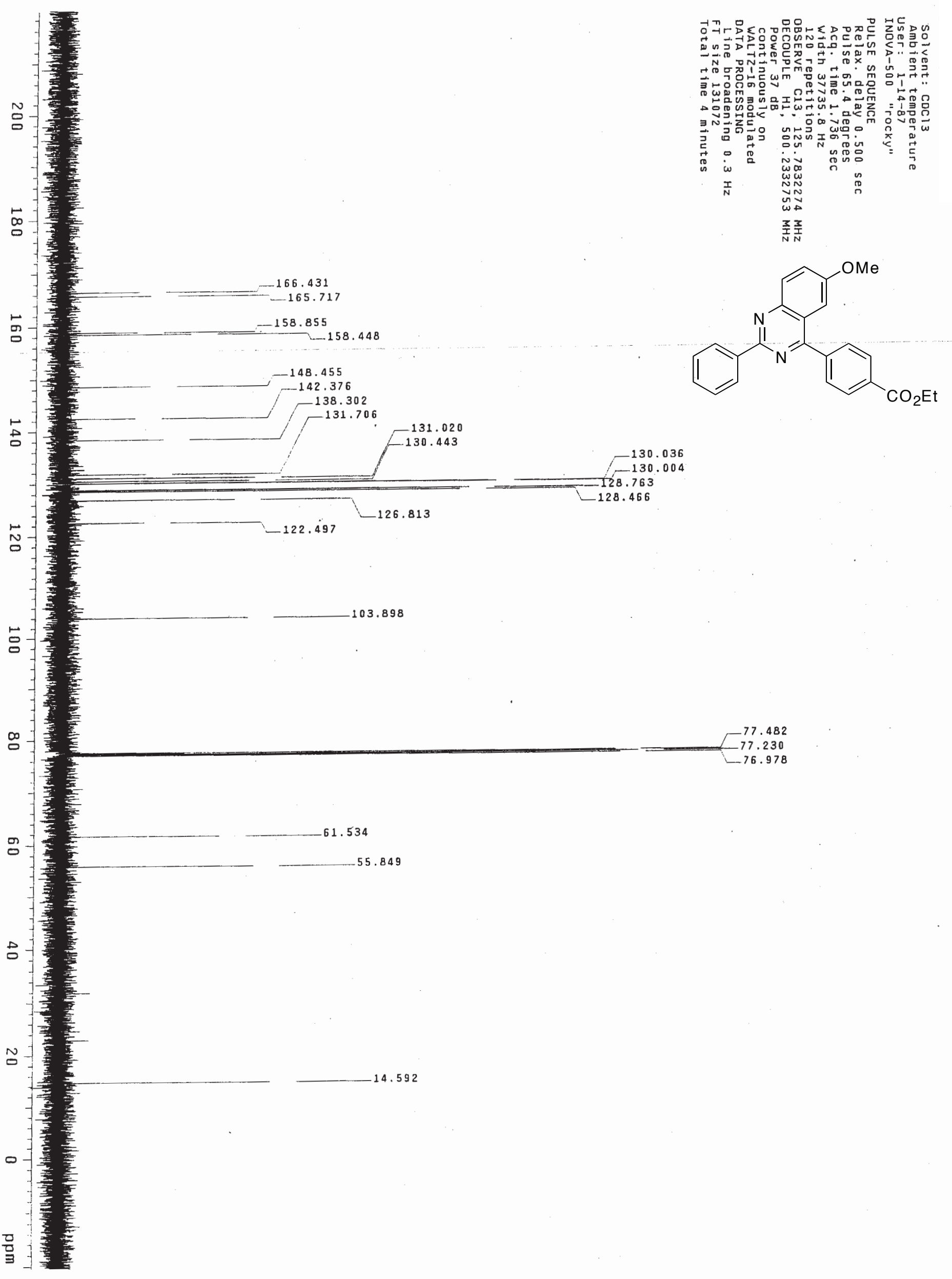




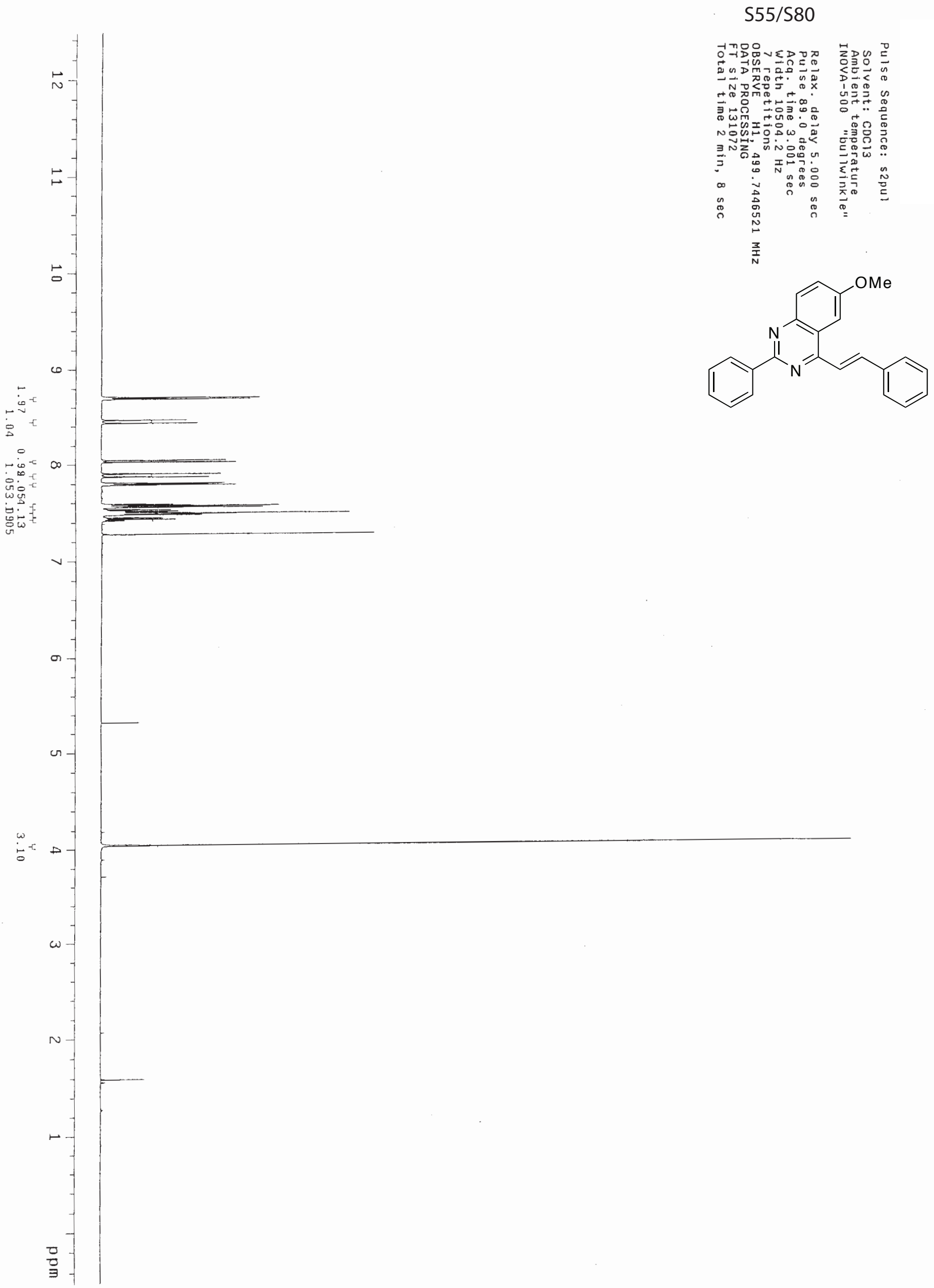




\section{S56/S80}

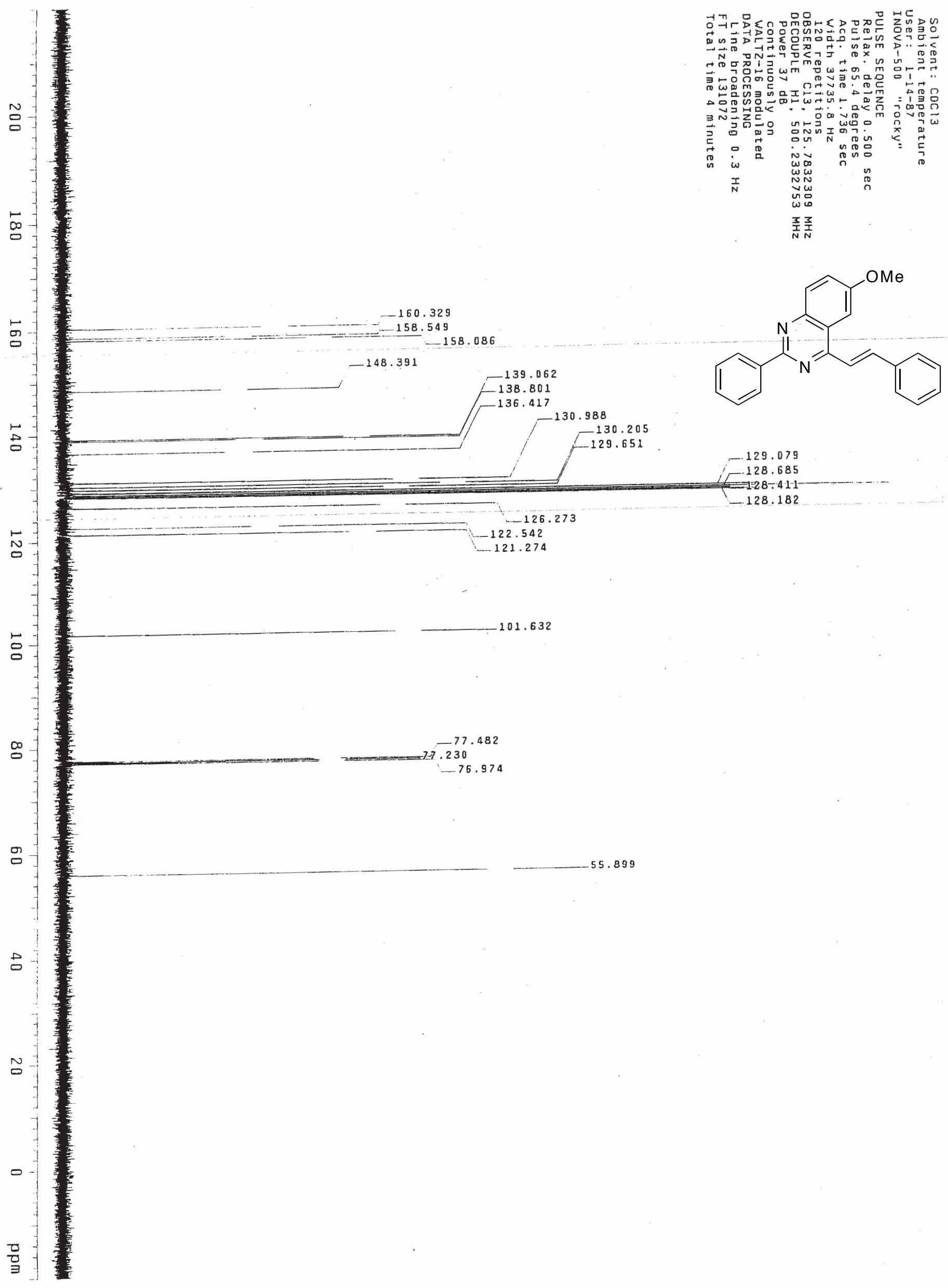




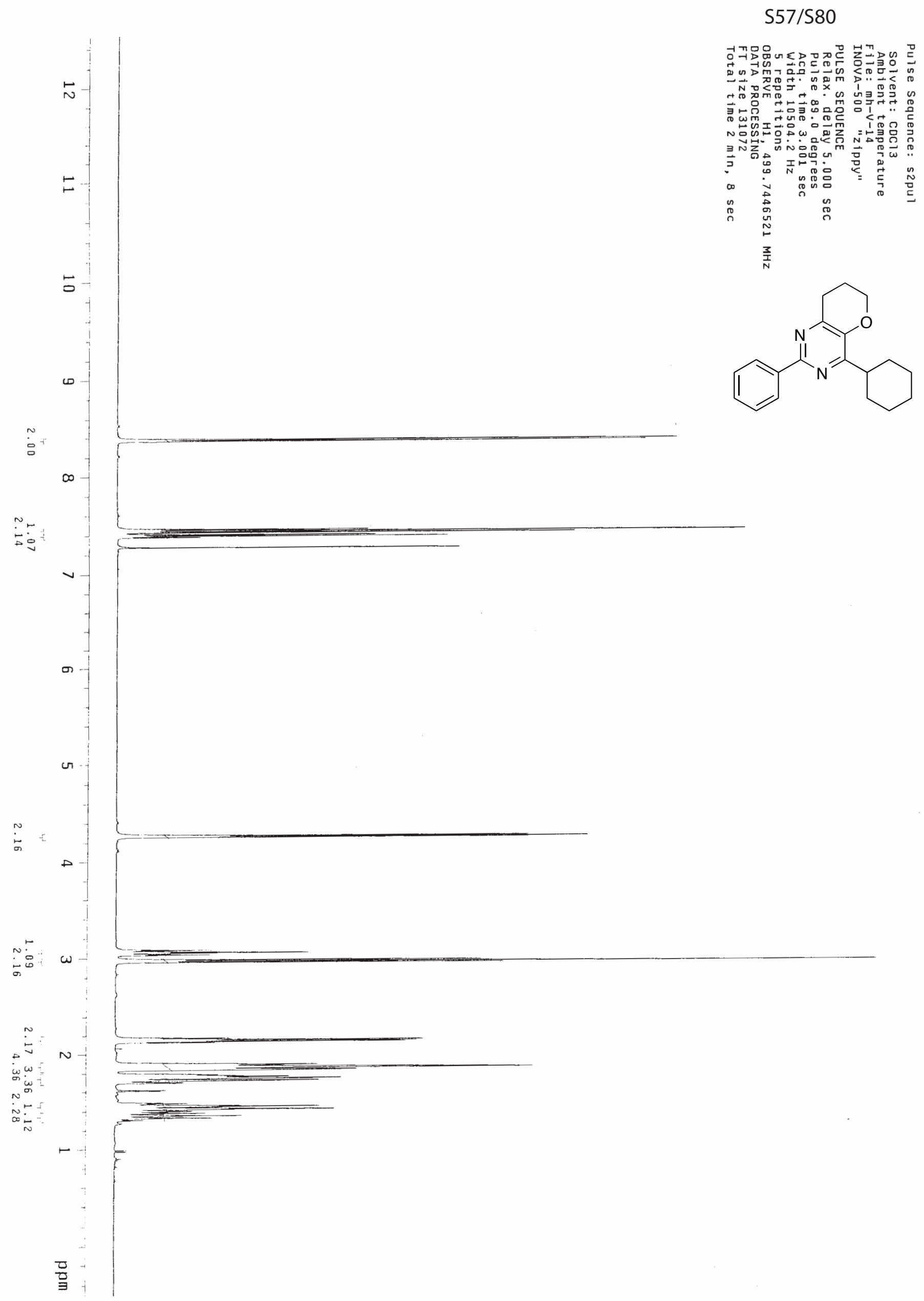




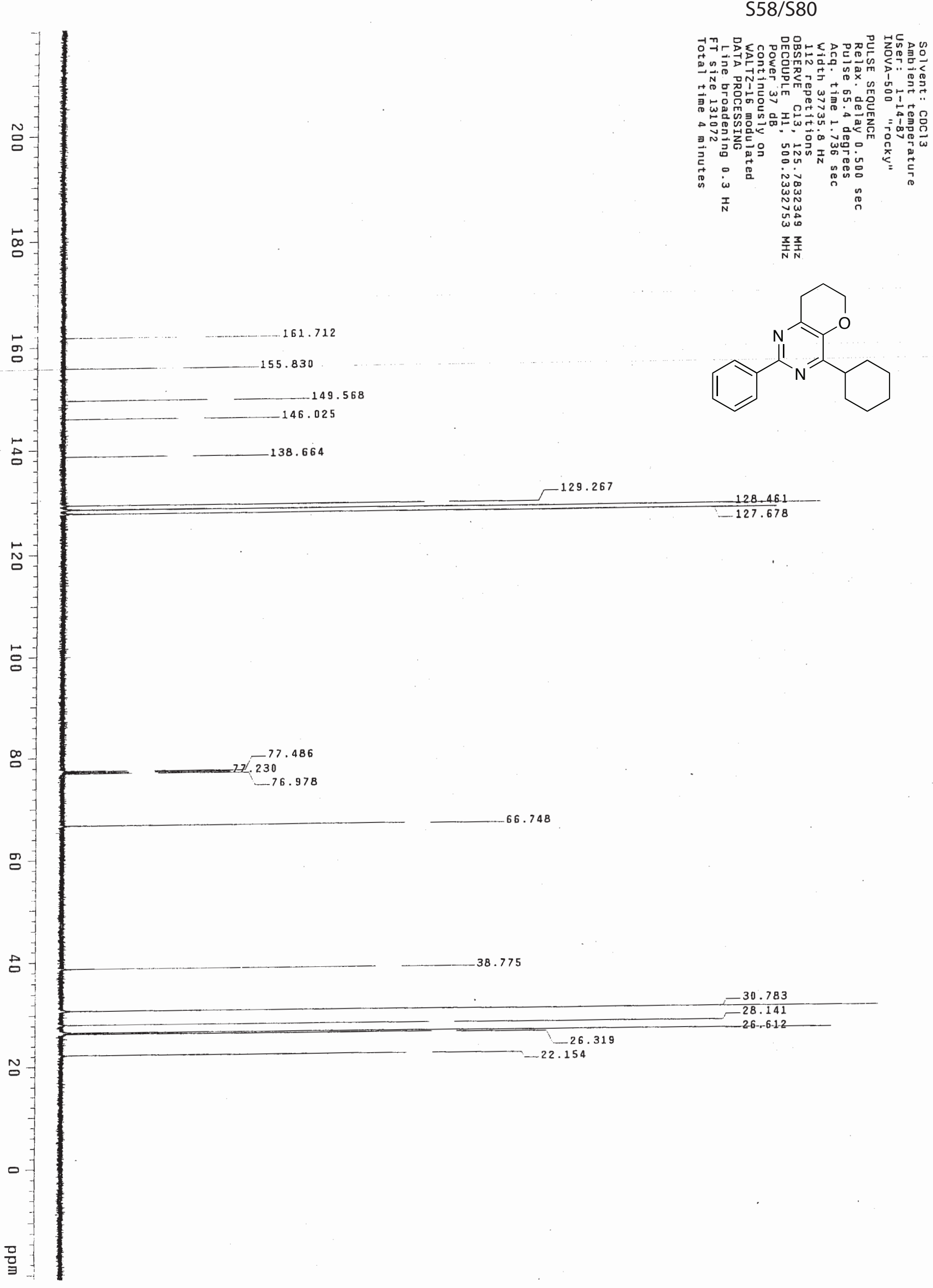




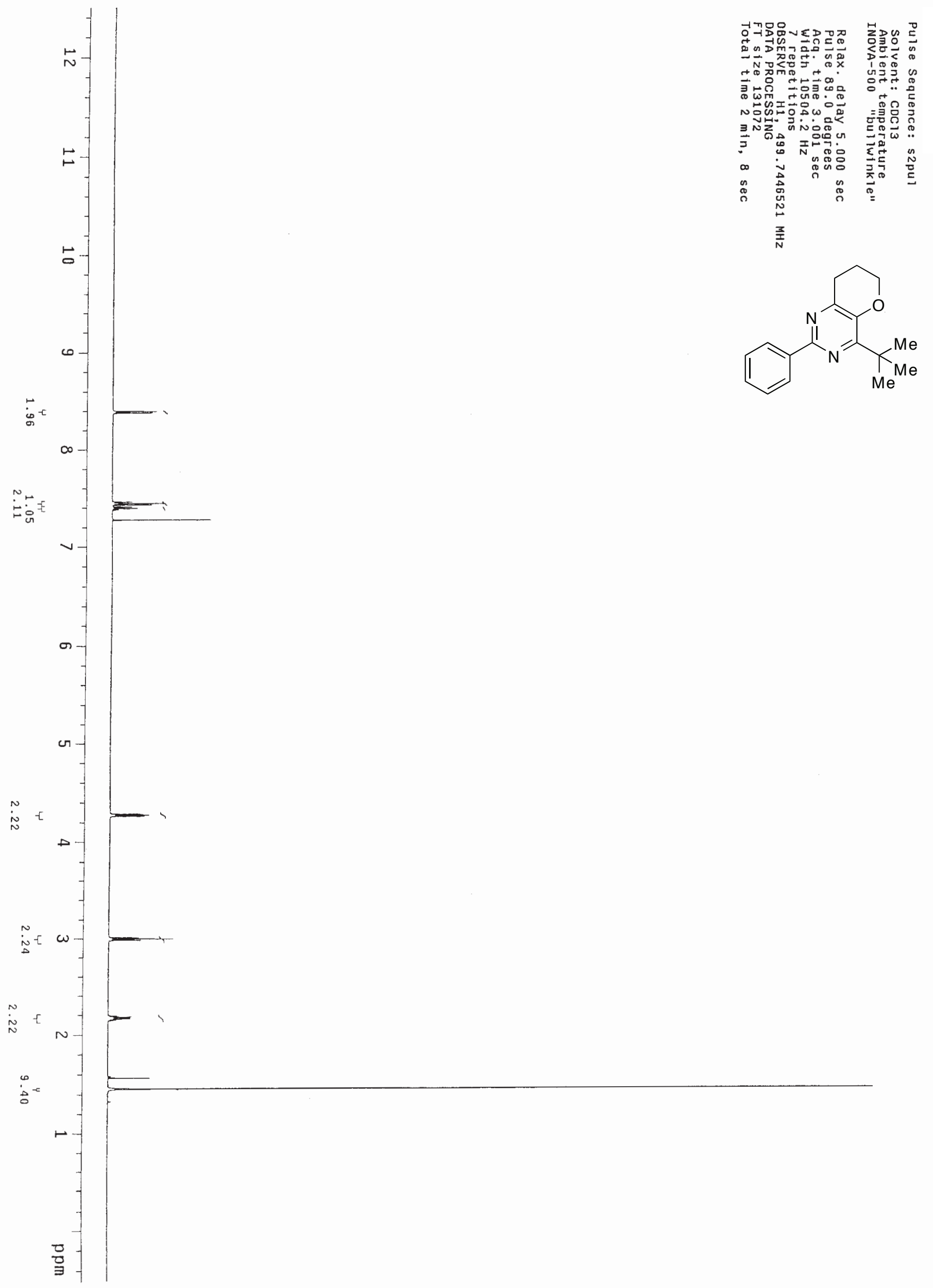




$$
1
$$




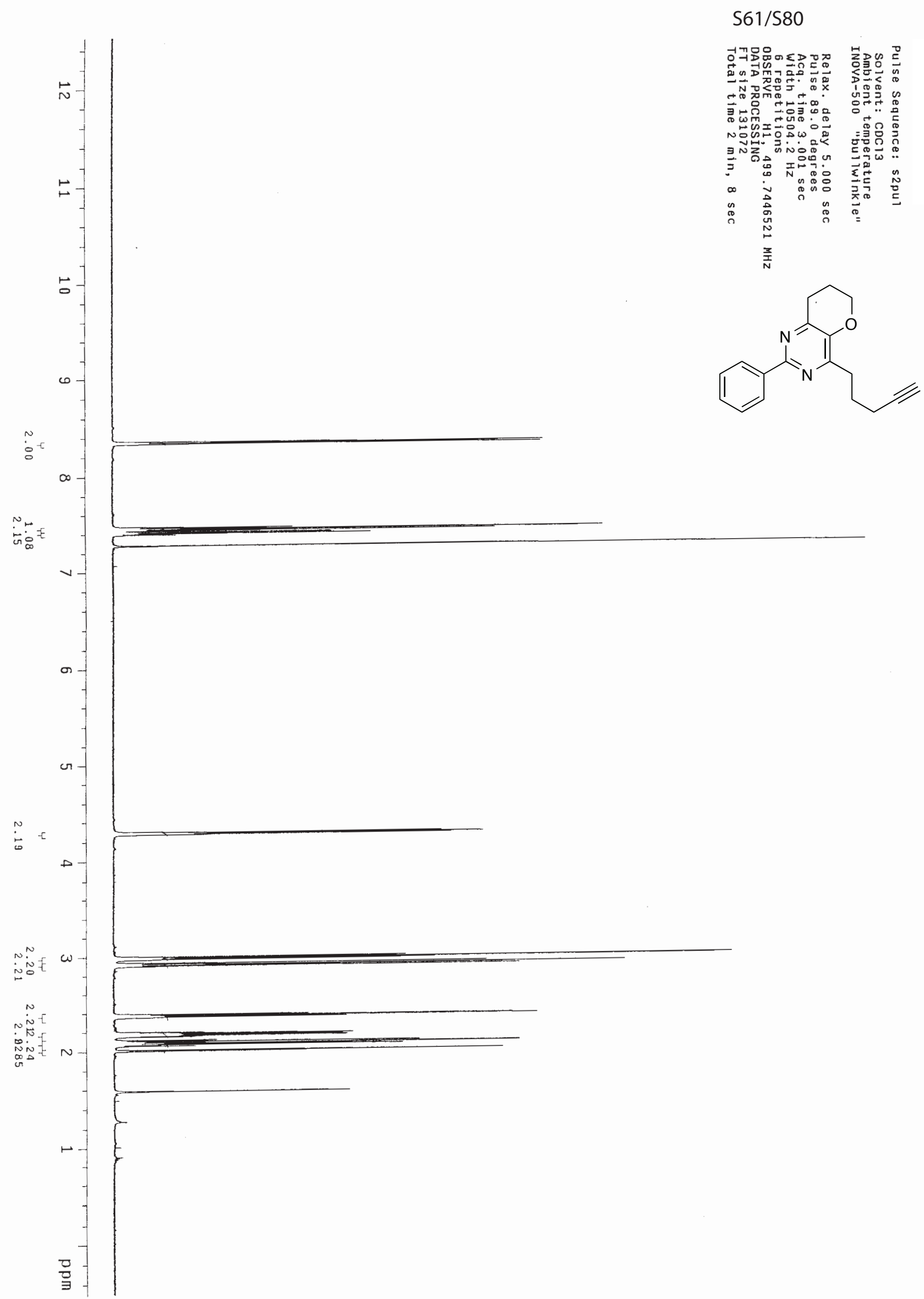




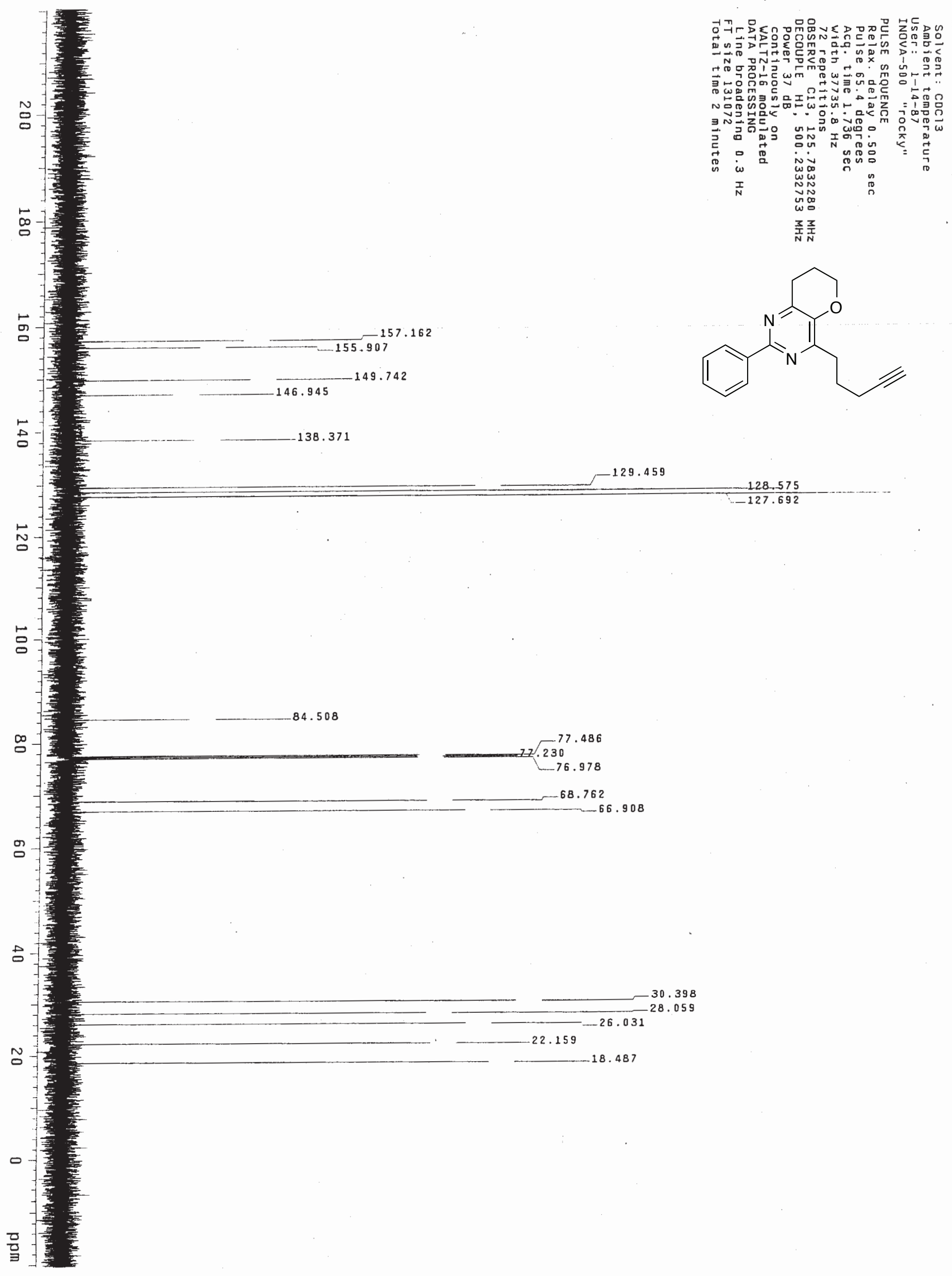




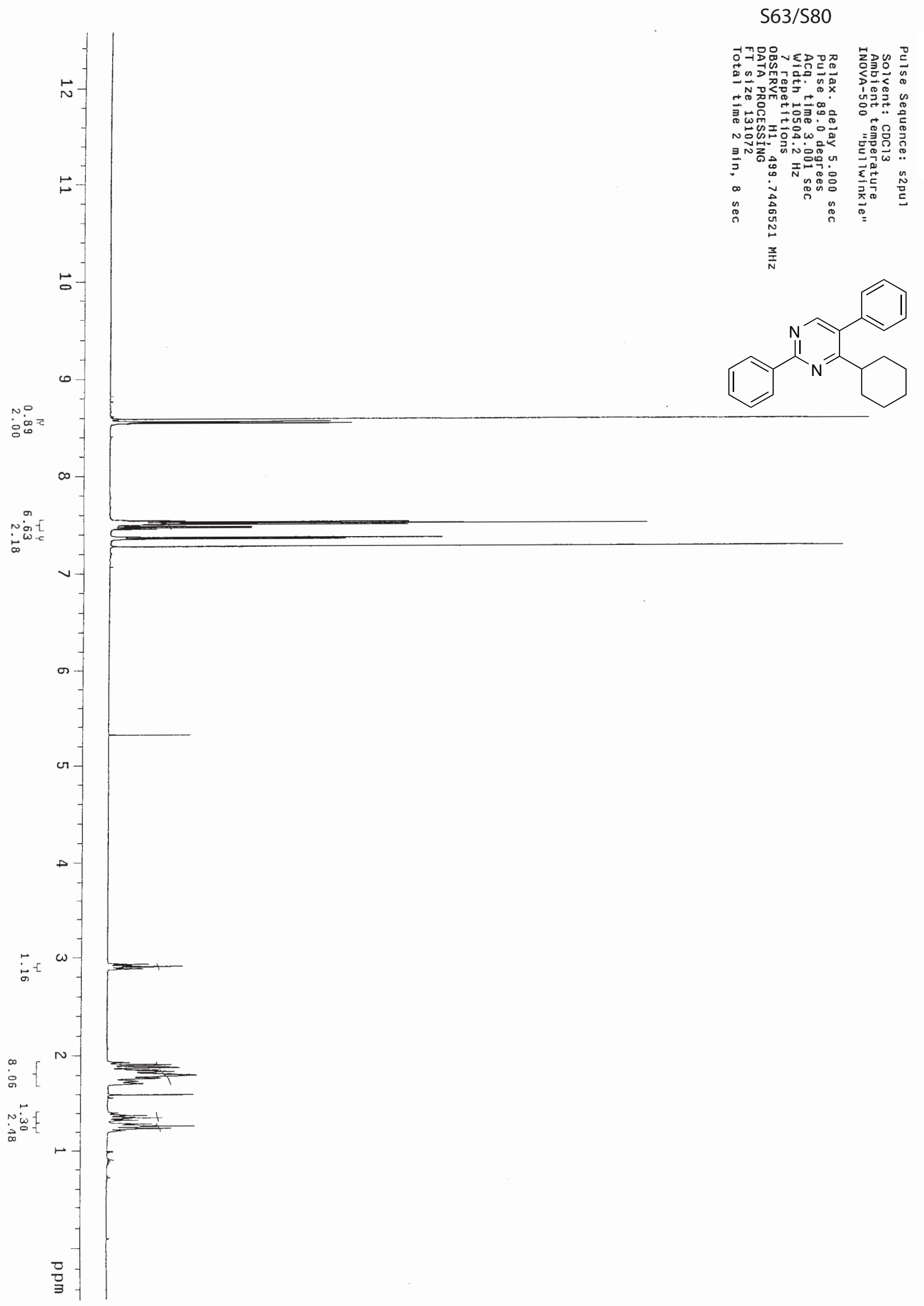




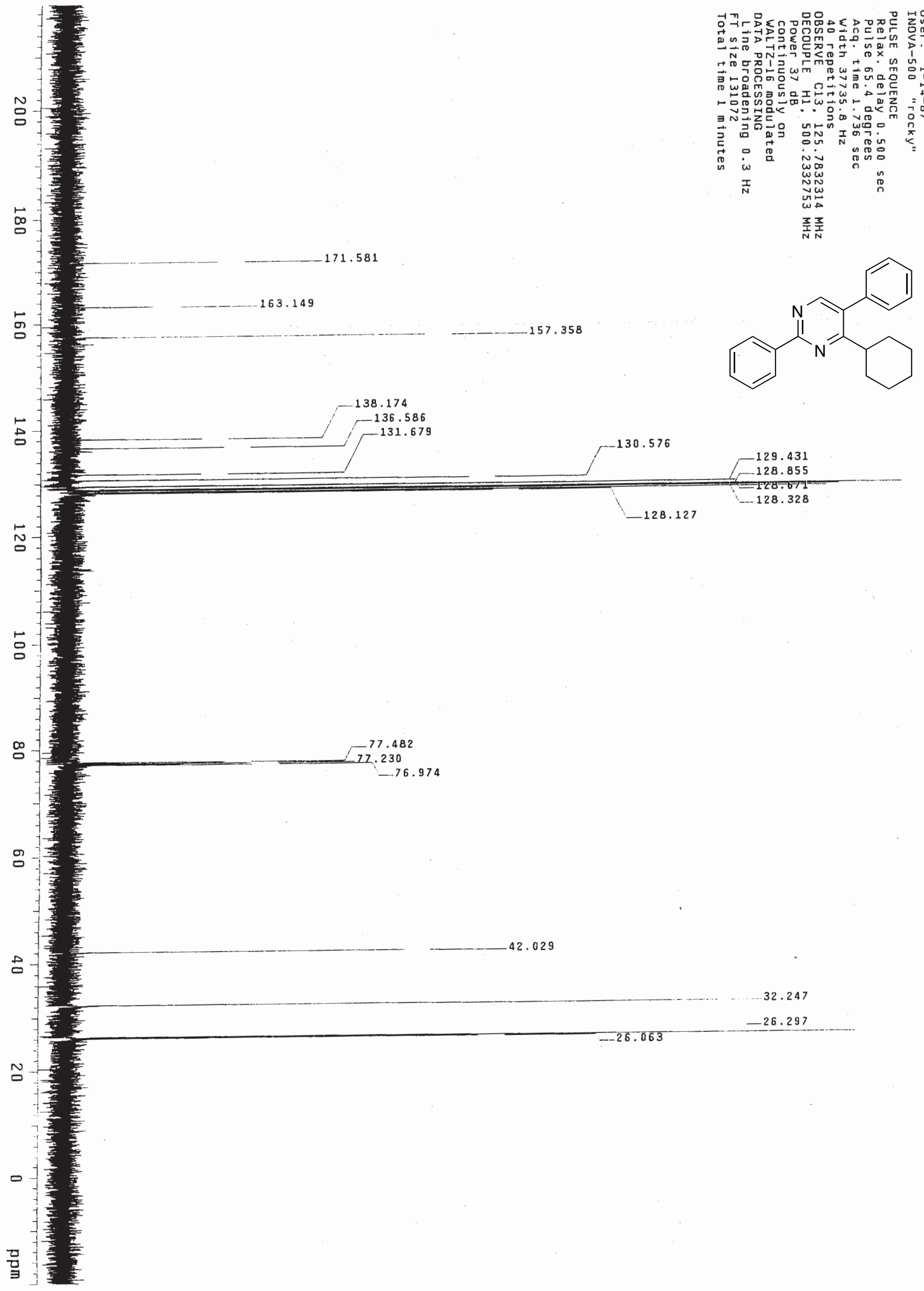




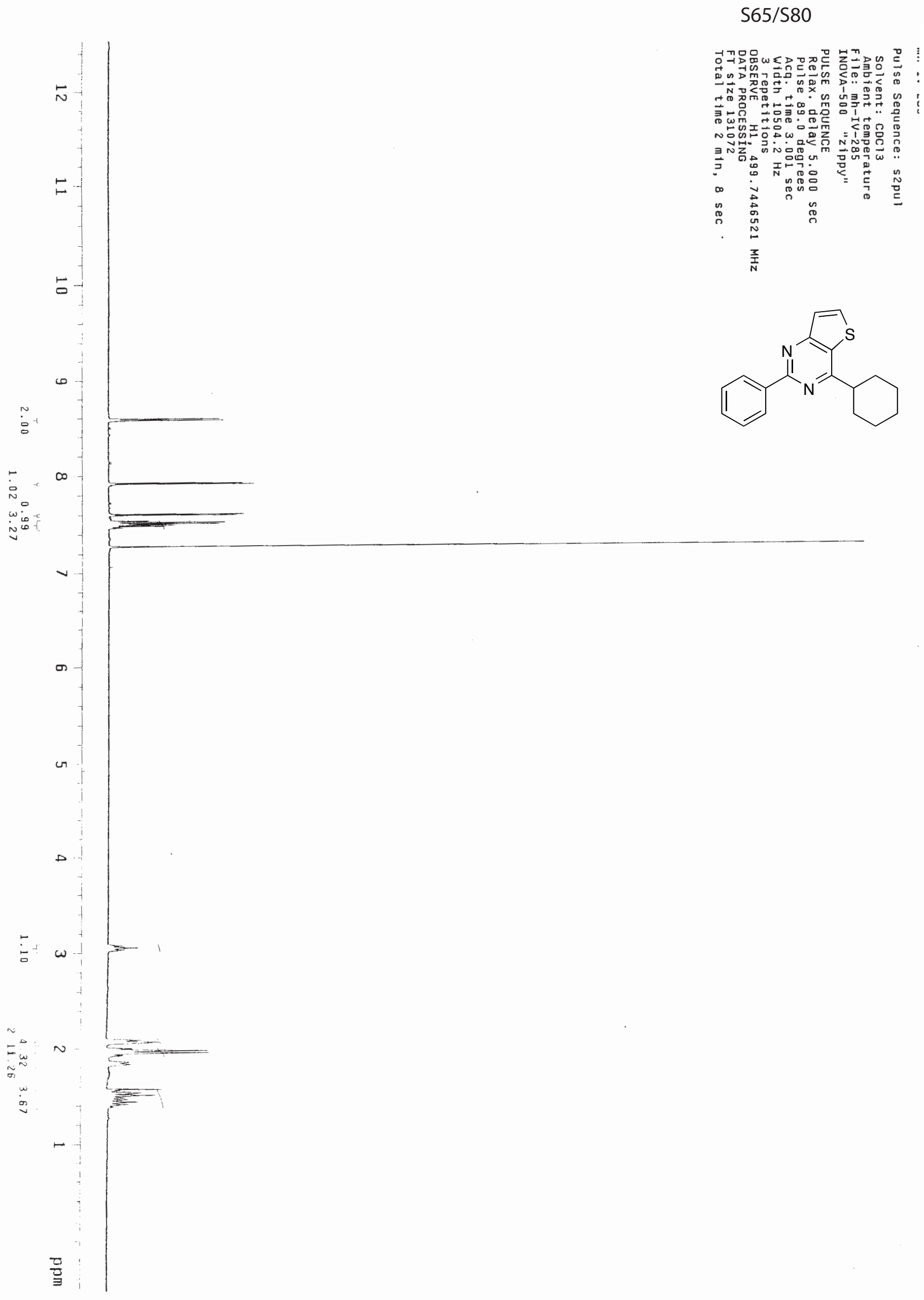




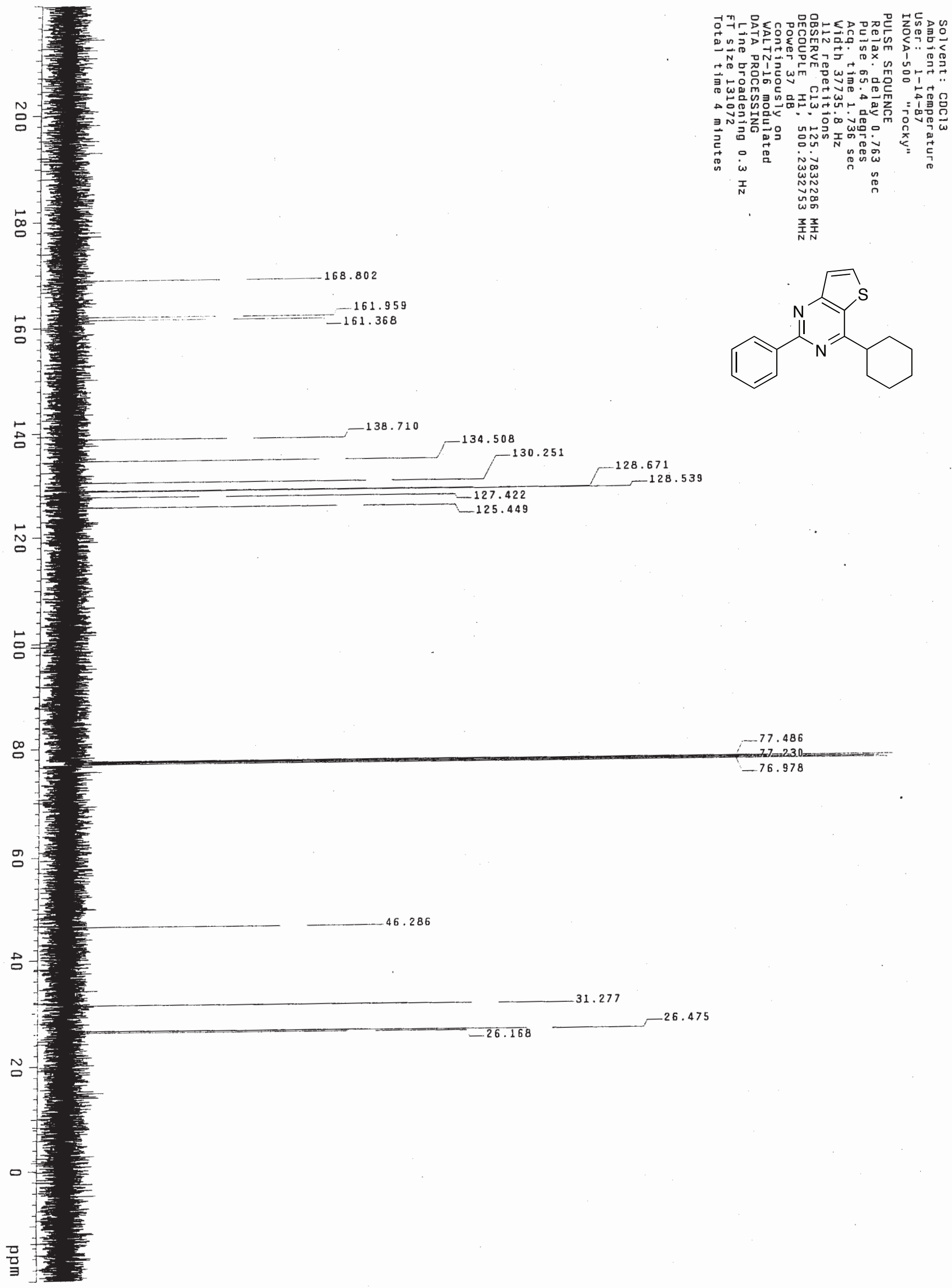




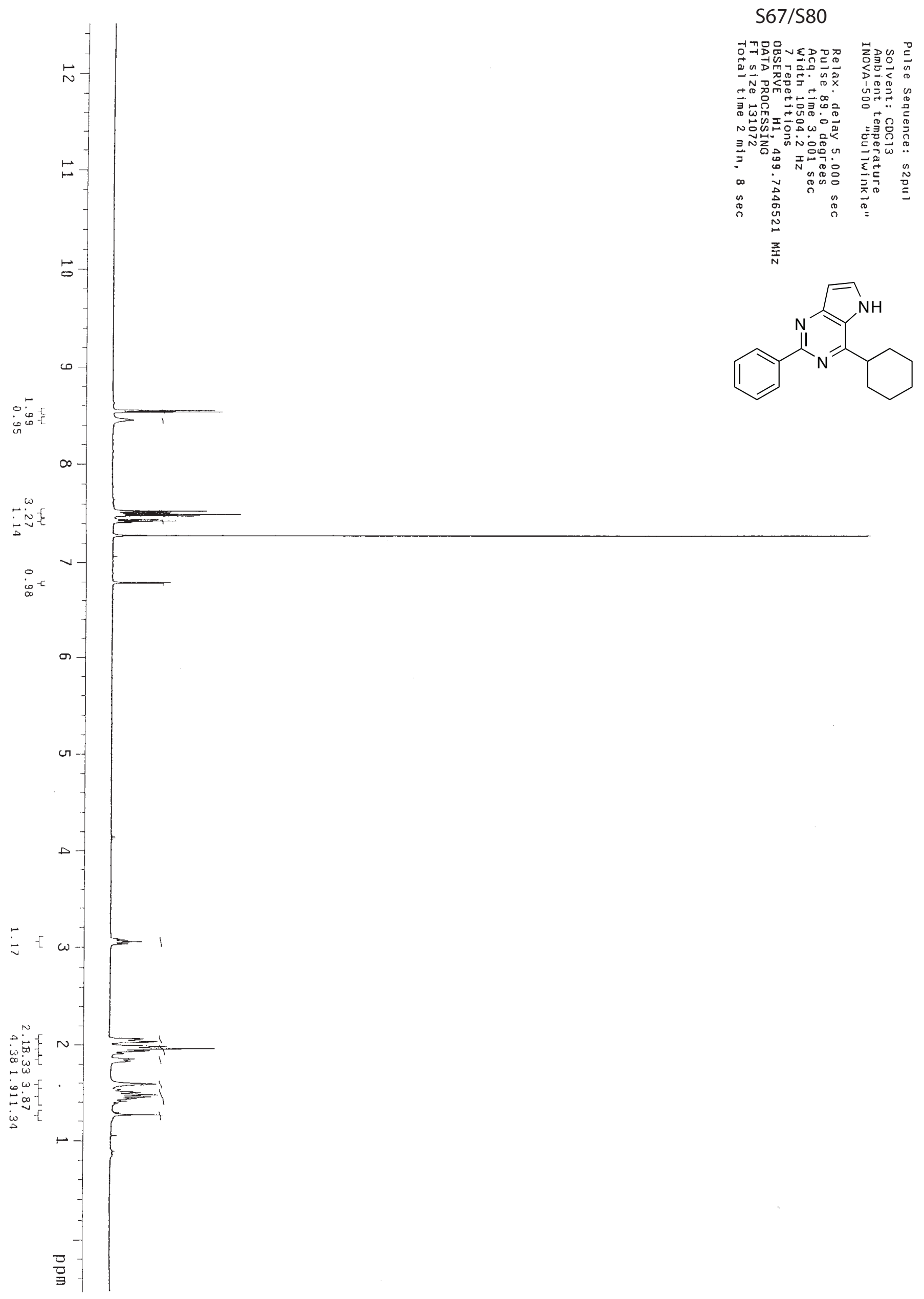




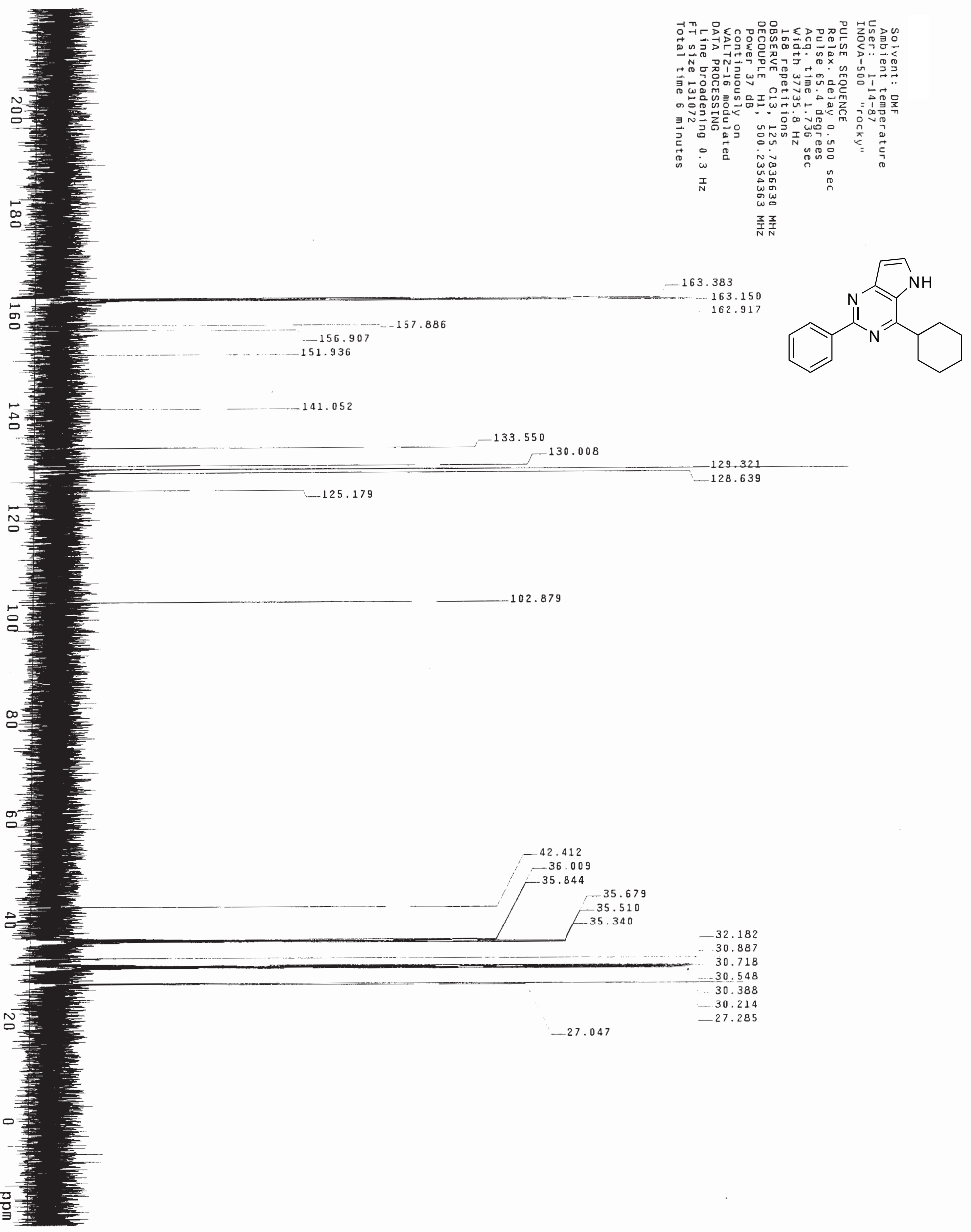




\section{$S 69 / S 80$}

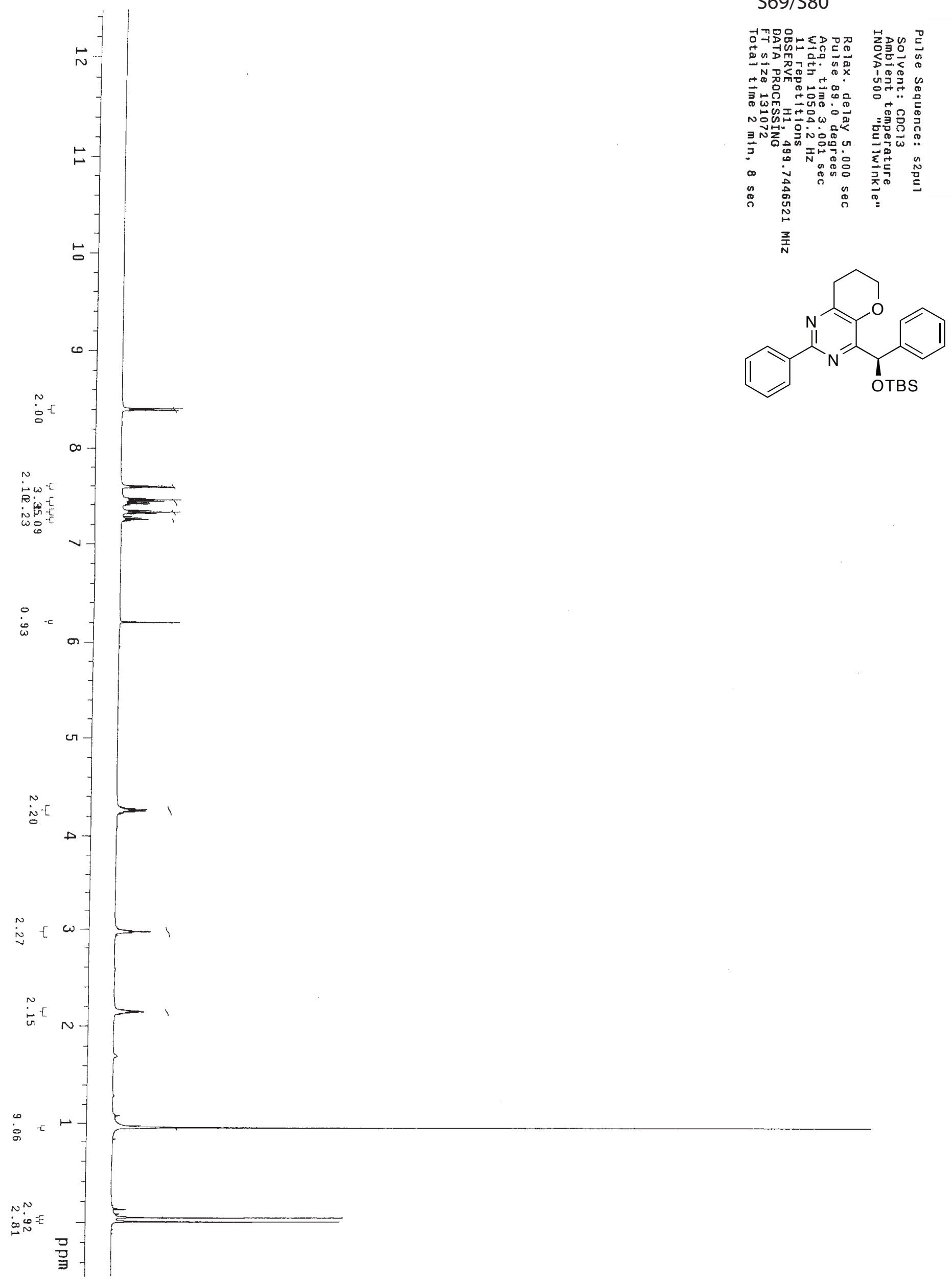




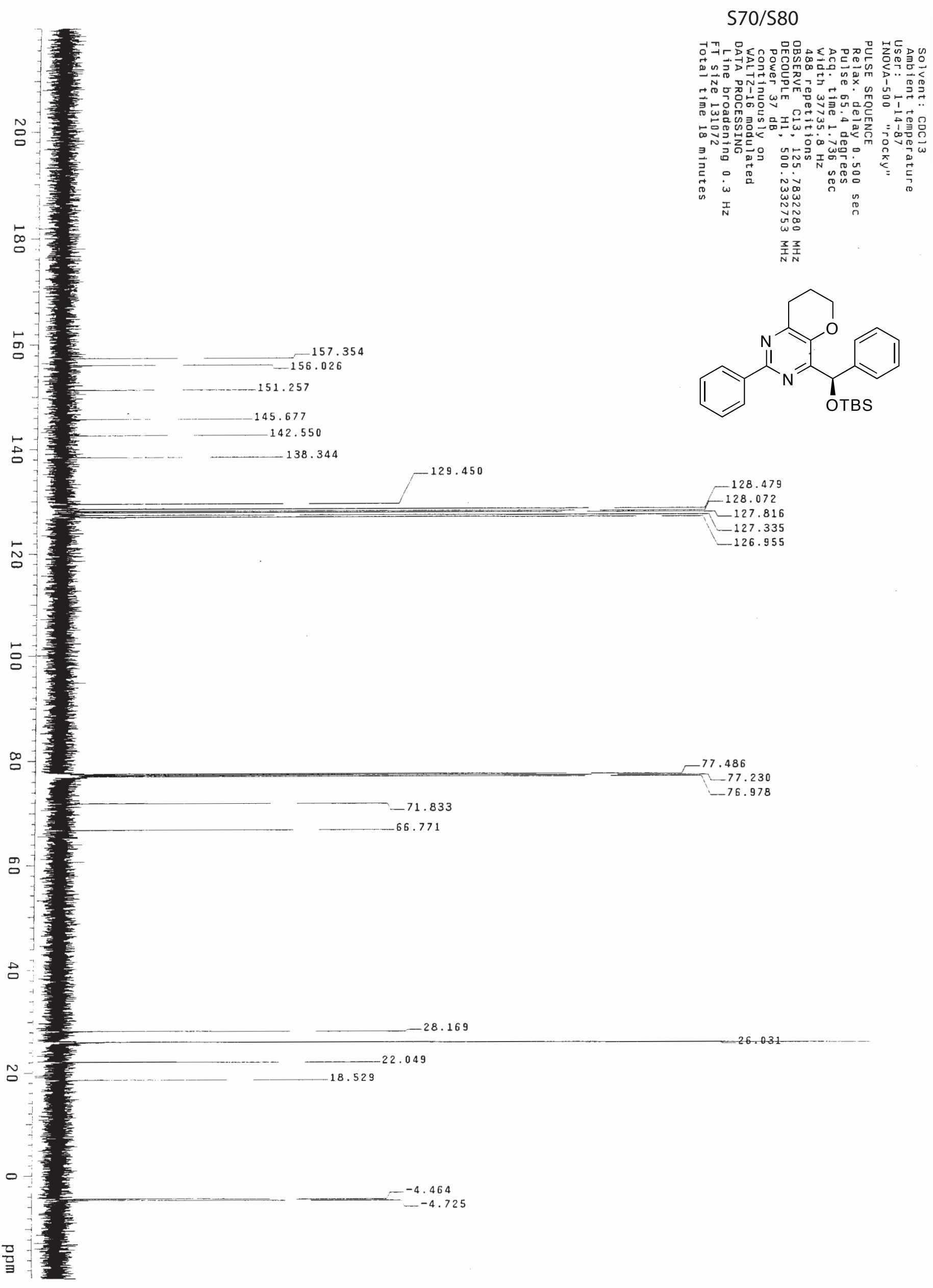


Data File C: $\backslash$ HPCHEM $\backslash 2 \backslash$ DATA $\backslash$ MHV6 7 .D

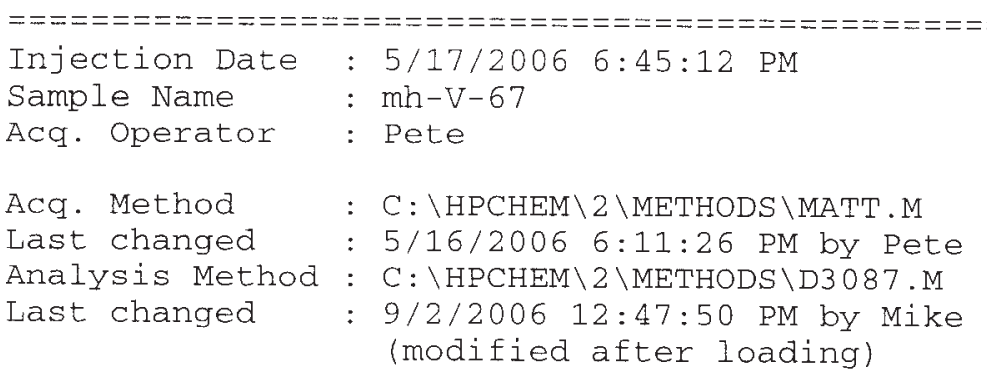

MWD1 A, Sig=220,16 Ref $=360,100($ MHV67.D)
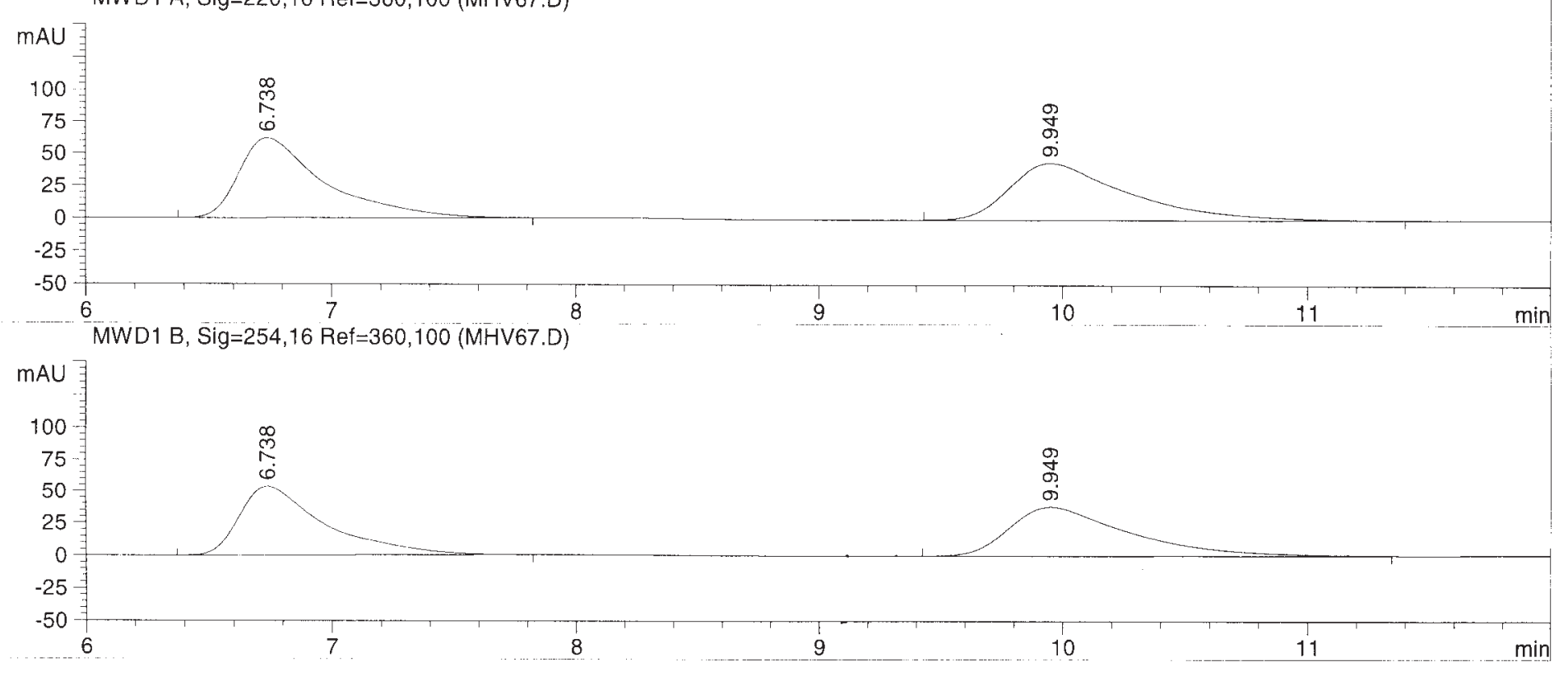

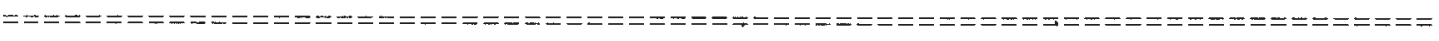

Area Percent Report

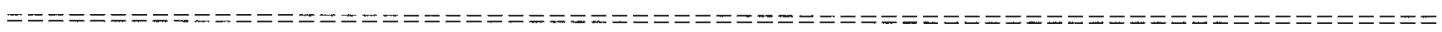

Sorted By

Multiplier

Dilution

Use Multiplier \& Dilution Factor with ISTDs

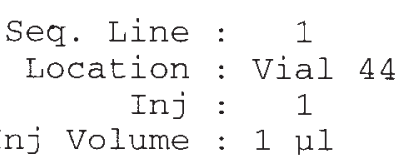

Inj Volume : $1 \mu 1$ 
Data File C: \HPCHEM \2\DATA \MHV71.D

\begin{tabular}{|c|c|}
\hline $\begin{array}{l}\text { Injection Date } \\
\text { Sample Name } \\
\text { Acq. Operator }\end{array}$ & $\begin{aligned}: & 5 / 17 / 2006 \quad 6: 27: 00 \mathrm{PM} \\
: & \text { mh-V-71 } \\
: & \text { Pete }\end{aligned}$ \\
\hline $\begin{array}{l}\text { Acq. Method } \\
\text { Last changed } \\
\text { Analysis Method } \\
\text { Last changed }\end{array}$ & 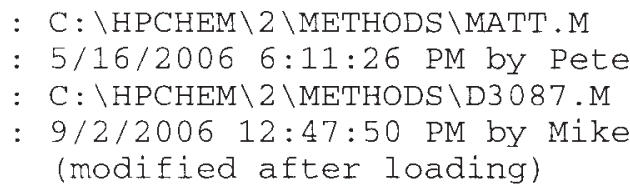 \\
\hline
\end{tabular}
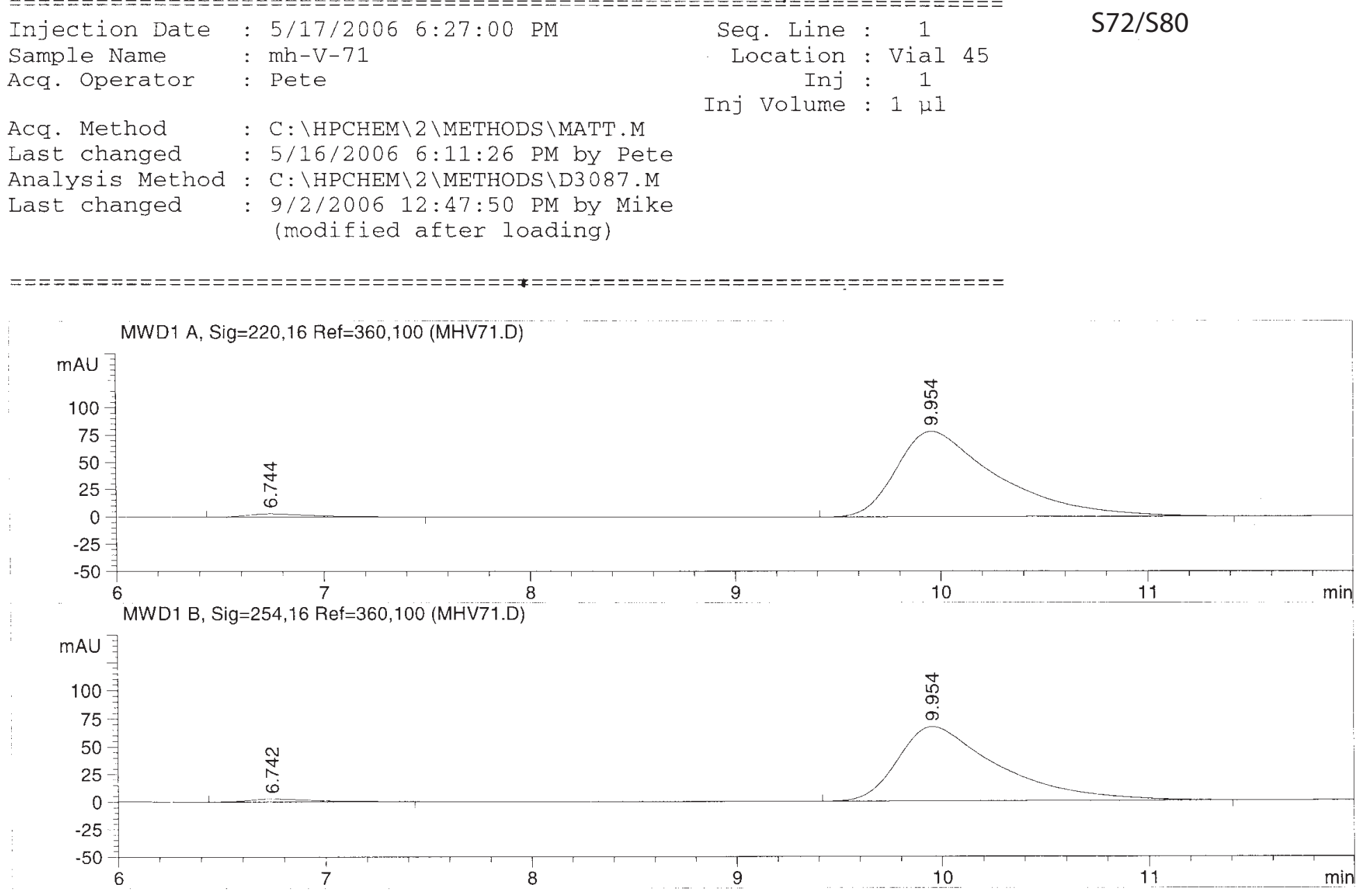

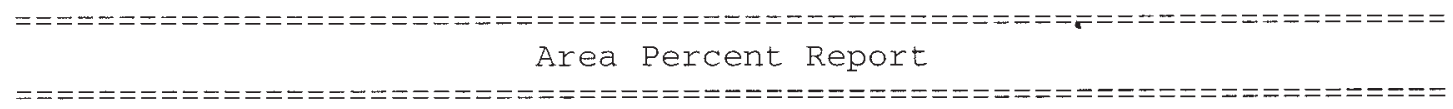

Sorted By : : Signal

Multiplier : : 1.0000

Dilution : $\quad 1.0000$

Use Multiplier \& Dilution Factor with ISTDs

Signal 1: MWD1 A, Sig=220,16 Ref=360,100

\begin{tabular}{|c|c|c|c|c|c|c|}
\hline $\begin{array}{c}\text { Peak } \\
\#\end{array}$ & $\begin{array}{c}\text { RetTime } \\
{[\mathrm{min}]}\end{array}$ & Type & $\begin{array}{l}\text { Width } \\
\text { [min] }\end{array}$ & $\begin{array}{c}\text { Area } \\
{\left[m A U^{*} \mathrm{~s}\right]}\end{array}$ & $\begin{array}{l}\text { Height } \\
{[\mathrm{mAU}]}\end{array}$ & $\begin{array}{c}\text { Area } \\
\text { 음 }\end{array}$ \\
\hline & & & & & & \\
\hline 1 & 6.744 & BB & 0.3266 & 67.53790 & 2.97821 & 2.4983 \\
\hline 2 & 9.954 & $\mathrm{~PB}$ & 0.4889 & 2635.80933 & 77.87540 & 97.5017 \\
\hline
\end{tabular}

Totals : $\quad 2703.34723 \quad 80.85362$

Results obtained with enhanced integrator!

Signal 2: MwD1 B, Sig=254,16 Ref=360,100

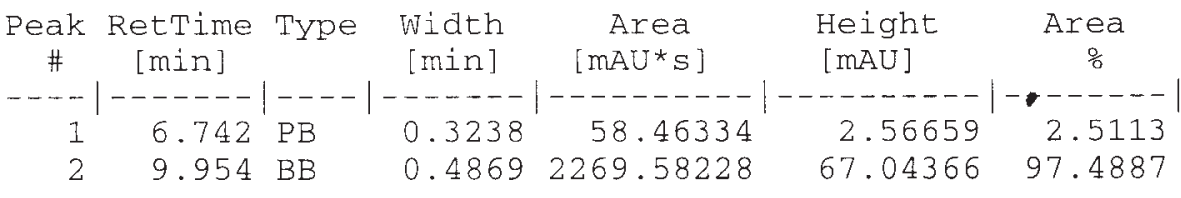

Totals : $\quad 2328.04562 \quad 69.61026$ 


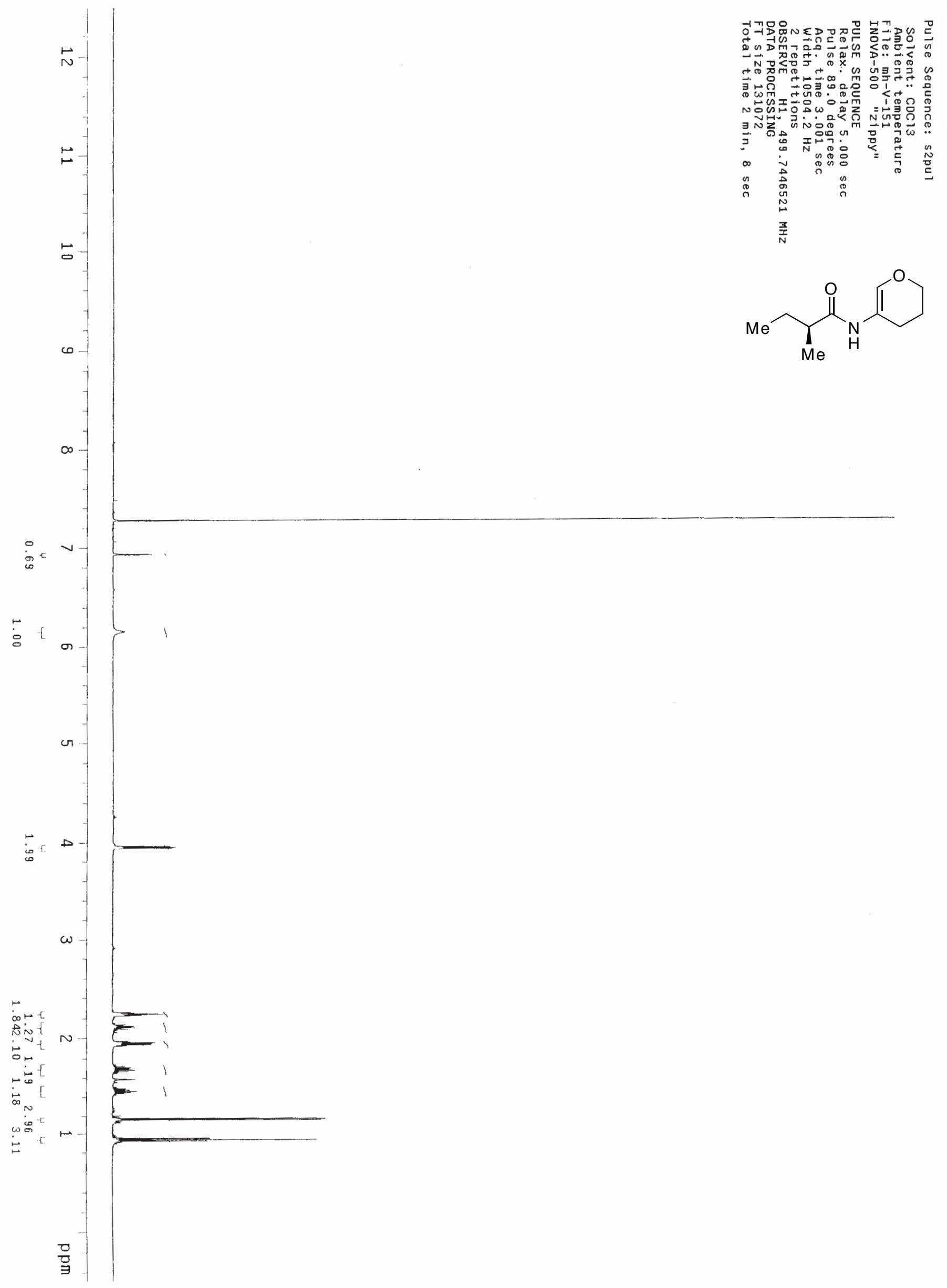




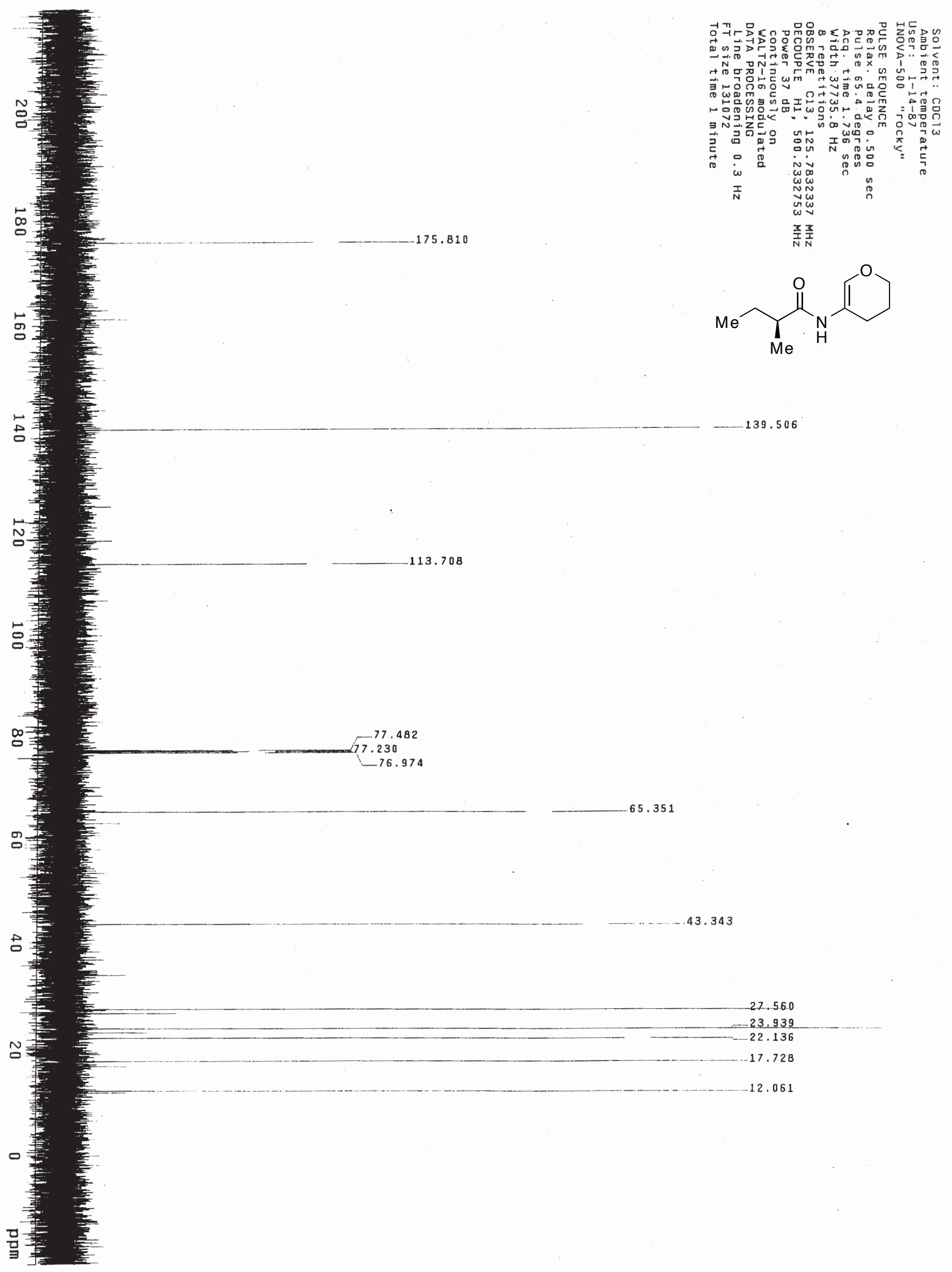


Data File C: \HPCHEM \2\DATA \MHV171.D

Racemis; Chiralcel OD $99 \%$ hex $1 \%$ IPA $0.5 \mathrm{ml} / \mathrm{min}$
$F======= \pm=$
Injection Date
: $8 / 22 / 2006$ 10:50:07 AM
Sample Name : mh-v-171
Acq. Operator: Mike
Acq. Method
$: C: \backslash$ HPCHEM $\backslash 2 \backslash M E T H O D S \backslash D 3087 . M$
wast changed
: 8/22/2006 10:50:23 AM by Mike (modified after loading)
Analysis Method : C: \HPCHEM $\backslash 2 \backslash$ METHODS $\backslash D 3087 . M$
Last changed : 9/2/2006 12:14:09 PM by Mike
(modified after loading)

Seq. Line :

Location : Vial 52

Inj : 1

Inj Volume : $1 \mu l$

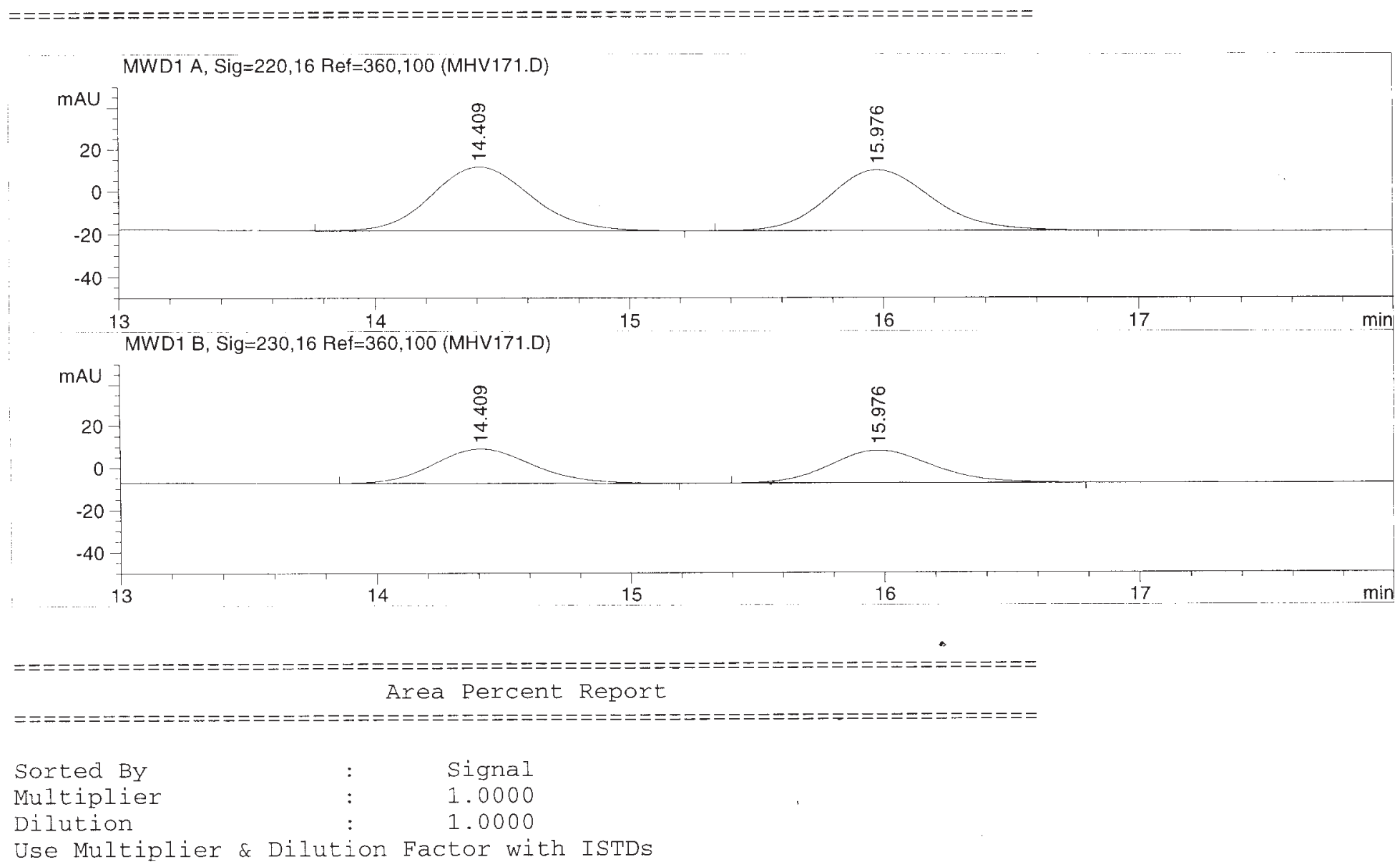

Signa1 1: MWD1 A, Sig=220,16 Ref $=360,100$

\begin{tabular}{|c|c|c|c|c|c|c|}
\hline $\begin{array}{c}\text { Peak } \\
\#\end{array}$ & $\begin{array}{c}\text { RetTime } \\
\text { [min] }\end{array}$ & Type & $\begin{array}{l}\text { Width } \\
\text { [min] }\end{array}$ & $\begin{array}{c}\text { Area } \\
{\left[m A U^{\star} s\right]}\end{array}$ & $\begin{array}{l}\text { Height } \\
\text { [mAU] }\end{array}$ & $\begin{array}{c}\text { Area } \\
\frac{\%}{0}\end{array}$ \\
\hline-- & & & ----- & -------- & -------- & - \\
\hline 1 & 14.409 & VP & 0.4294 & 817.90497 & 29.87720 & 6648 \\
\hline 2 & 15.976 & $B B$ & 0.4386 & 796.44165 & 28.27765 & 49.3352 \\
\hline
\end{tabular}

Totals :

$1614.34662 \quad 58.15485$

Results obtained with enhanced integrator!

Signal 2: MWD1 B, Sig=230,16 Ref $=360,100$

\begin{tabular}{|c|c|c|c|c|c|c|}
\hline $\begin{array}{c}\text { Peak } \\
\#\end{array}$ & $\begin{array}{c}\text { RetTime } \\
\text { [min] }\end{array}$ & Type & $\begin{array}{l}\text { Width } \\
\text { [min] }\end{array}$ & $\begin{array}{c}\text { Area } \\
{\left[\mathrm{mA} U^{\star} s\right]}\end{array}$ & $\begin{array}{l}\text { Height } \\
\text { [mAU] }\end{array}$ & $\begin{array}{c}\text { Area } \\
\%\end{array}$ \\
\hline-- & $-\cdots$ & & ---- & ---------- & ------- & --- \\
\hline 1 & 14.409 & $B B$ & 0.4259 & 445.15985 & 16.43794 & 3785 \\
\hline 2 & 15.976 & $\mathrm{BB}$ & 0.4316 & 438.47003 & 15.61679 & 6215 \\
\hline
\end{tabular}


Data File C: \HPCHEM $\backslash 2 \backslash D A T A \backslash M H V 172 . D$

Racemis; Chiralcel OD $99 \%$ hex 1\% IPA $0.5 \mathrm{ml} / \mathrm{min}$

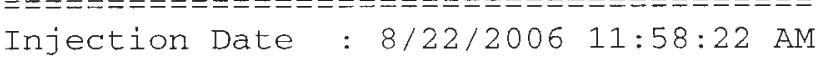

Sample Name : $m h-v-172$

Acq. Operator : Mike

Acq. Method

Last changed

Analysis Method:

Last changed
: C : \HPCHEM $\backslash 2 \backslash$ METHODS $\backslash D 3087 . \mathrm{M}$ : 8/22/2006 11:57:39 AM by Mike

: C: \HPCHEM $\backslash 2 \backslash M E T H O D S \backslash D 3087 . \mathrm{M}$ : 9/2/2006 12:26:23 PM by Mike (modified after loading)

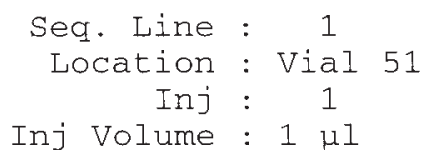

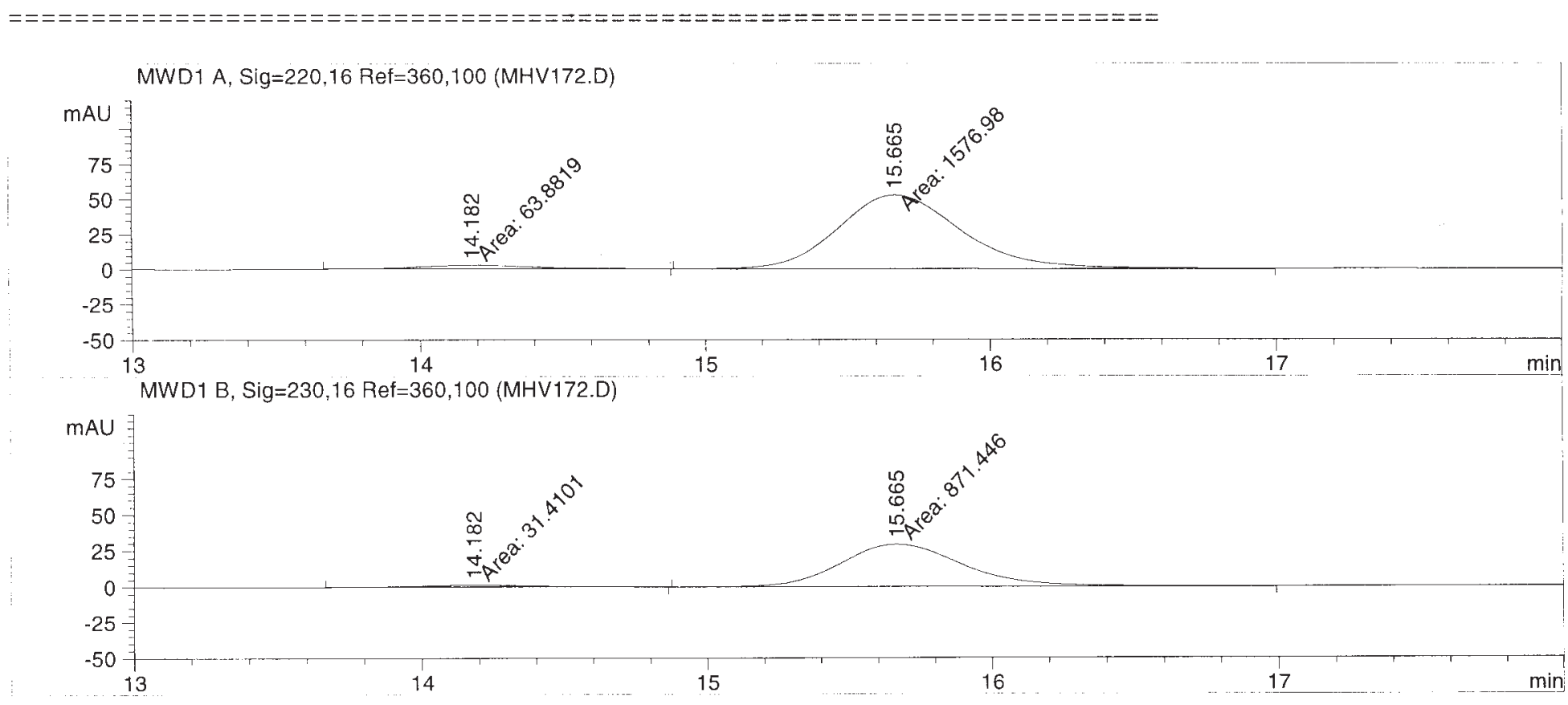

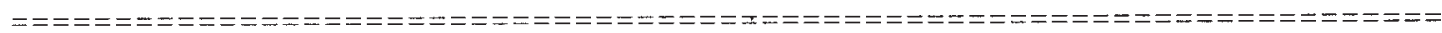
Area Percent Report

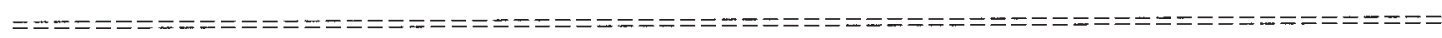

Sorted By

Multiplier

Dilution

Use Multiplier \& Dilution Factor with ISTDs
Signal

1.0000

1.0000

Signal 1: MwD1 A, Sig=220,16 Ref=360,100

\begin{tabular}{|c|c|c|c|c|c|c|}
\hline $\begin{array}{c}\text { Peak } \\
\#\end{array}$ & $\begin{array}{c}\text { RetTime } \\
\text { [min] }\end{array}$ & Type & $\begin{array}{l}\text { Width } \\
\text { [min] }\end{array}$ & $\begin{array}{c}\text { Area } \\
{\left[\mathrm{mAU}^{\star} \mathrm{s}\right]}\end{array}$ & $\begin{array}{l}\text { Height } \\
\text { [mAU] }\end{array}$ & $\begin{array}{c}\text { Area } \\
\%\end{array}$ \\
\hline & & & & & & \\
\hline 1 & 14.182 & MM & 0.4311 & 63.88190 & 2.46999 & 3932 \\
\hline 2 & 15.665 & MM & 0.5027 & 1576.97693 & 52.28671 & 1068 \\
\hline
\end{tabular}

Totals :

$1640.85883 \quad 54.75670$

Results obtained with enhanced integrator!

Signal 2: MWD1 B, Sig=230,16 $\operatorname{Ref}=360,100$

\begin{tabular}{|c|c|c|c|c|c|c|}
\hline $\begin{array}{c}\text { Peak } \\
\#\end{array}$ & $\begin{array}{c}\text { RetTime } \\
\text { [min] }\end{array}$ & Type & $\begin{array}{l}\text { Width } \\
\text { [min] }\end{array}$ & $\begin{array}{c}\text { Area } \\
{\left[\mathrm{mAU}^{*} \mathrm{~s}\right]}\end{array}$ & $\begin{array}{l}\text { Height } \\
\text { [mAU] }\end{array}$ & $\begin{array}{c}\text { Area } \\
\frac{8}{\circ}\end{array}$ \\
\hline & & & & $-------\ldots$ & ------ & $\cdots \cdots$ \\
\hline 1 & 14.18 & MM & 0.4046 & 31.41007 & 1.29372 & 3.4790 \\
\hline 2 & 15.665 & MM & .5021 & 871.44592 & 28.92579 & 96.5210 \\
\hline
\end{tabular}

Totals :

902.85600

30.21951 


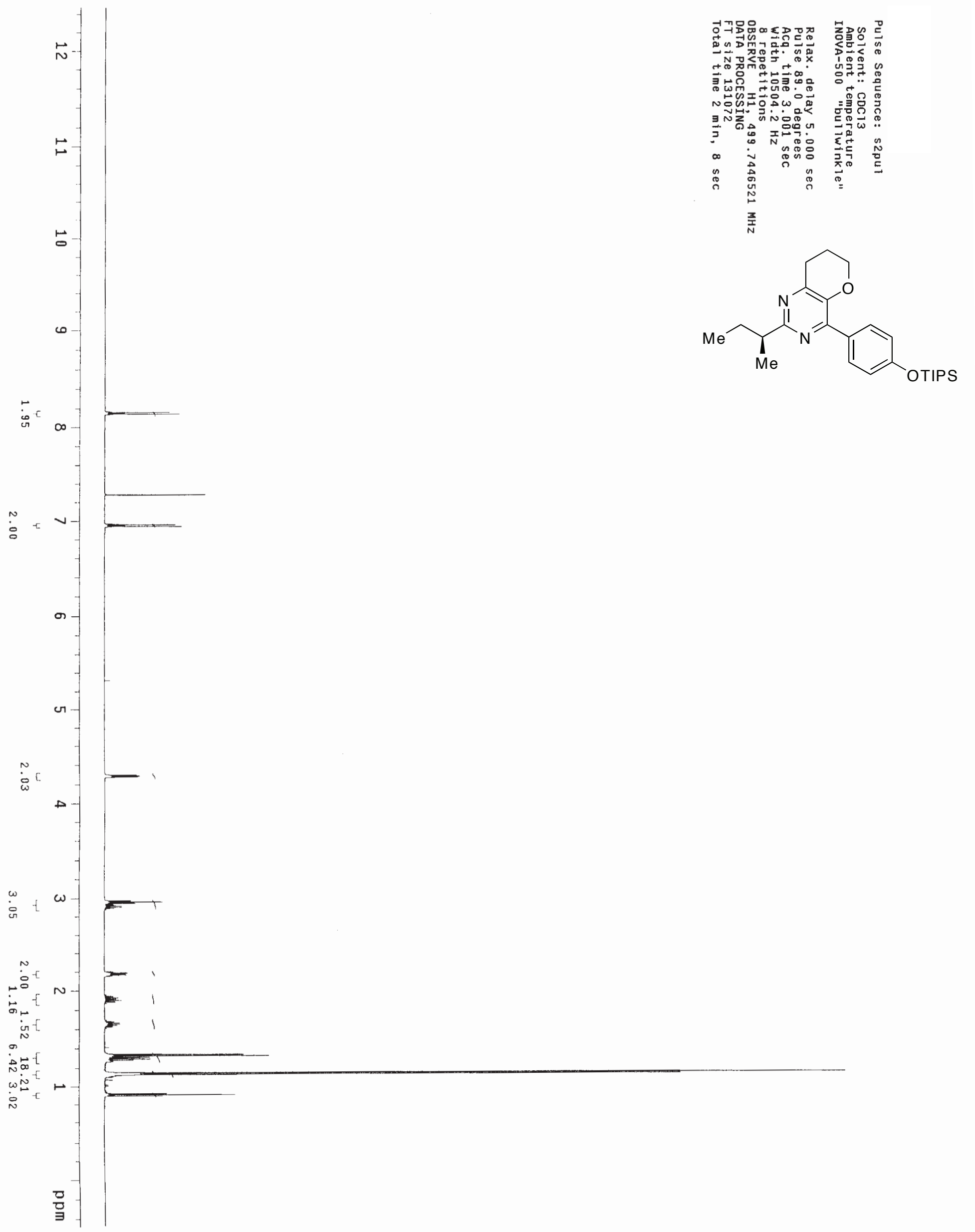




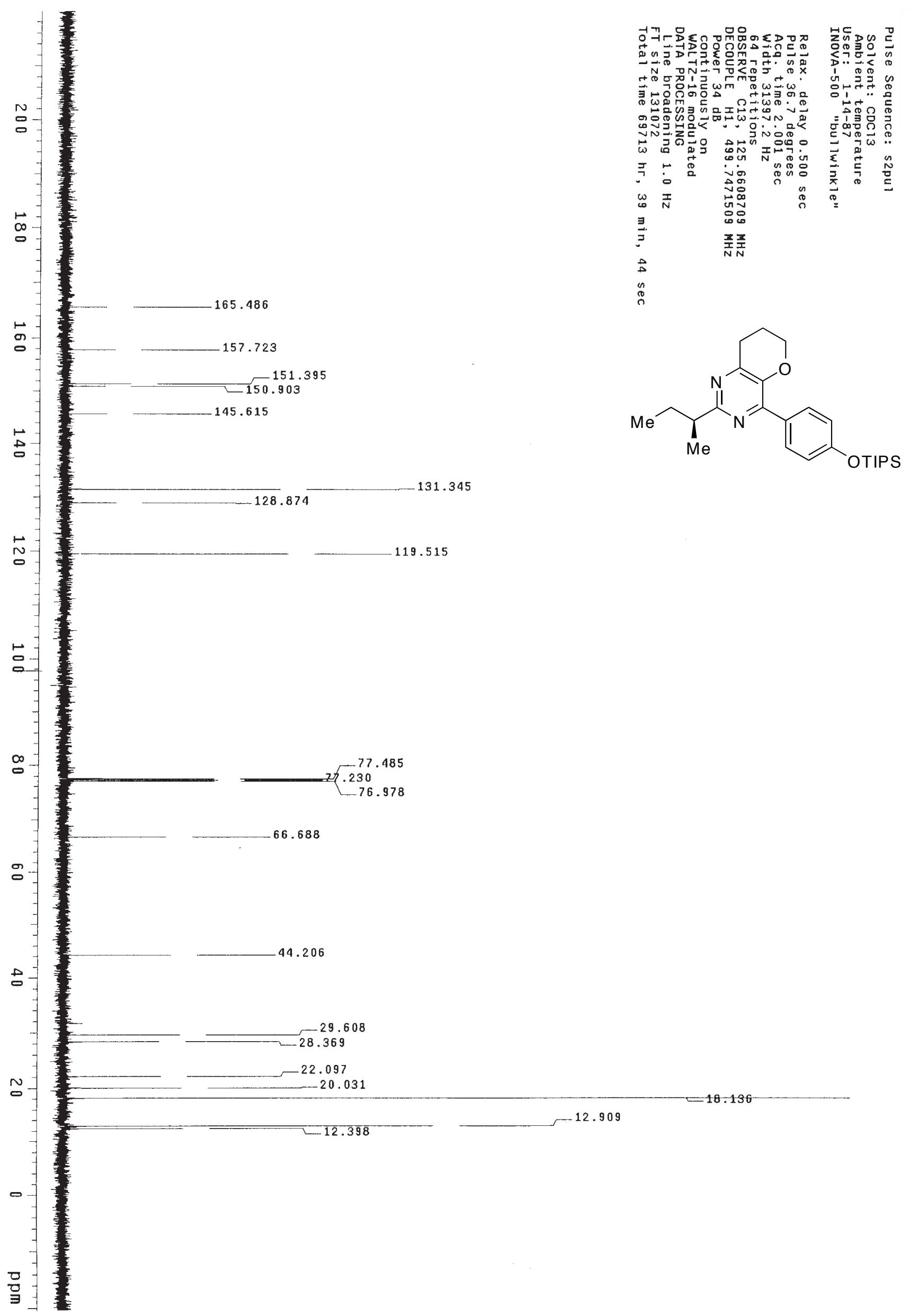


Data File C: \HPCHEM \2\DATA \MHV169.D

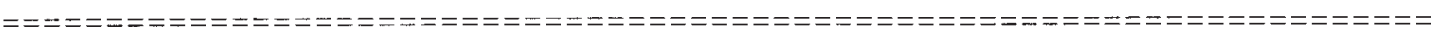

Injection Date : 9/2/2006 12:22:20 PM

Seq. Line : 1

Location : Vial 31

Sample Name : mh-V-169

Inj : 1

Acq. Operator : Mike

Inj Volume : $1 \mu 1$

Acq. Method : C: $\backslash$ HPCHEM $\backslash 2 \backslash$ METHODS $\backslash$ MATT.M

Last changed : 9/2/2006 12:21:32 PM by Mike

Analysis Method : C: \HPCHEM $\backslash 2 \backslash$ METHODS $\backslash D 3087 . M$

Last changed : 9/2/2006 12:43:49 PM by Mike

(modified after loading)

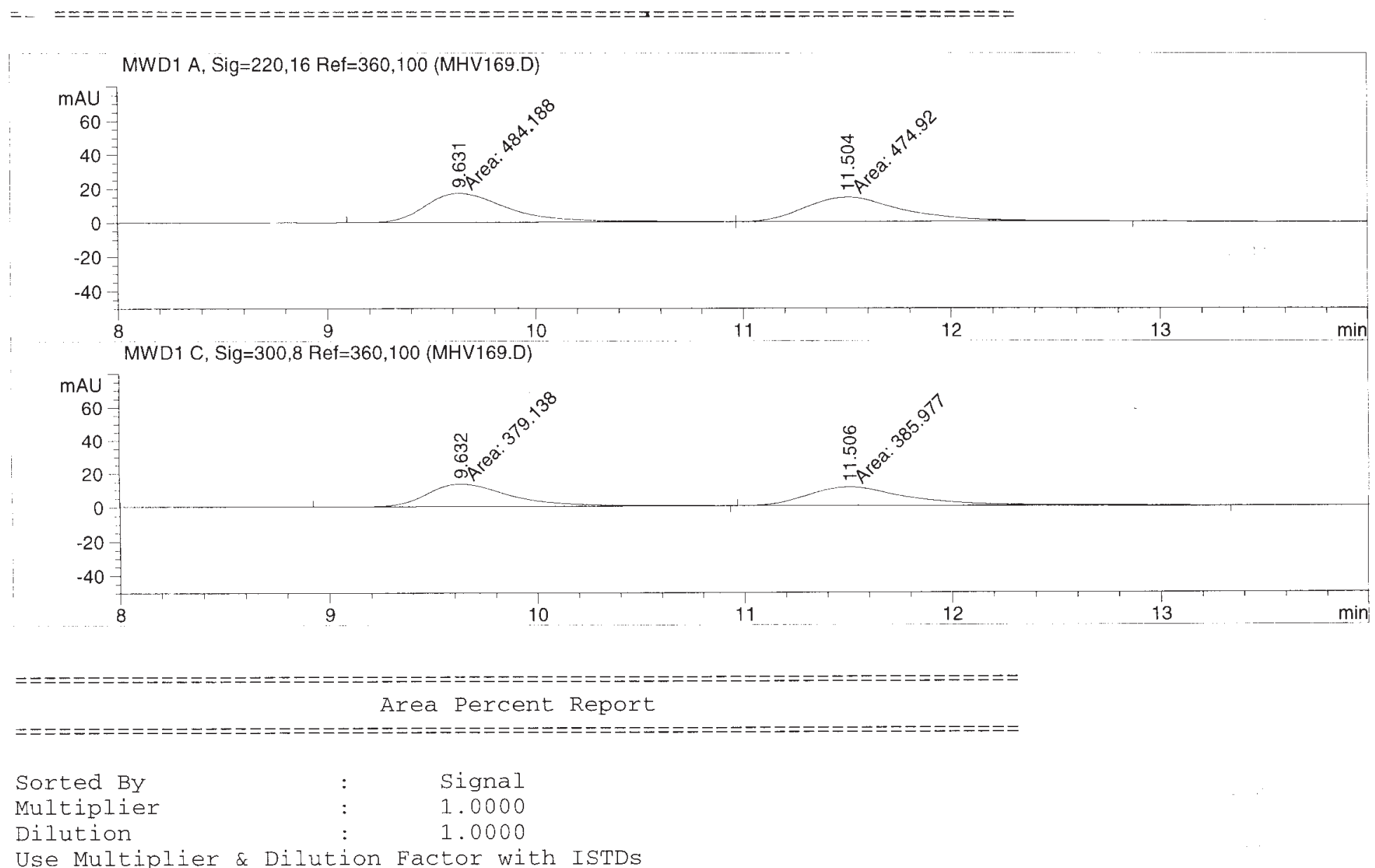

Signa1 1: MWD1 A, Sig=220,16 Ref=360,100

\begin{tabular}{|c|c|c|c|c|c|c|}
\hline $\begin{array}{c}\text { Peak } \\
\#\end{array}$ & $\begin{array}{c}\text { RetTime } \\
\text { [min] }\end{array}$ & Type & $\begin{array}{l}\text { Width } \\
\text { [min] }\end{array}$ & $\begin{array}{c}\text { Area } \\
{\left[m A U^{*} s\right]}\end{array}$ & $\begin{array}{l}\text { Height } \\
{[\text { mAU }]}\end{array}$ & $\begin{array}{c}\text { Area } \\
\text { 응 }\end{array}$ \\
\hline 年 & 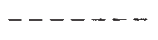 & & $-\cdots-$ & --------- & ----- & ------ \\
\hline 1 & $53+3$ & MM & 0.4723 & 484.18787 & 17.08 & 50.483 \\
\hline 2 & 11.50 & IM & .5551 & 474.92029 & 14.26056 & 49.5169 \\
\hline
\end{tabular}

Totals :

$959.10815 \quad 31.34710$

Results obtained with enhanced integrator!

Signal 2: MWD1 C, $\operatorname{Sig}=300,8$ Ref $=360.100$

\begin{tabular}{|c|c|c|c|c|c|c|}
\hline $\begin{array}{c}\text { Peak } \\
\#\end{array}$ & $\begin{array}{c}\text { RetTime } \\
\text { [min] }\end{array}$ & Type & $\begin{array}{l}\text { Width } \\
\text { [min] }\end{array}$ & $\begin{array}{c}\text { Area } \\
{\left[\mathrm{mAU}^{*} \mathrm{~s}\right]}\end{array}$ & $\begin{array}{l}\text { Height } \\
{[\mathrm{mAU}]}\end{array}$ & $\begin{array}{c}\text { Area } \\
\%\end{array}$ \\
\hline & & & ------- & $\cdots------1$ & & $-\cdots------$ \\
\hline 1 & 9.632 & MM & 0.4717 & 379.13776 & 13.39615 & 49.5530 \\
\hline 2 & 11.506 & MM & 0.5841 & 385.97714 & 11.01431 & 50.4470 \\
\hline+ & & & & 765.11490 & 41047 & \\
\hline
\end{tabular}


Data File C: $\backslash$ HPCHEM $\backslash 2 \backslash D A T A \backslash M H V 183 . D$

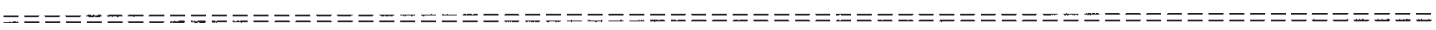

Injection Date : 8/26/2006 10:53:00 AM

Seq. Line : 1

Location : Vial 81

Sample Name : mh-V-183

Inj : 1

Acq. Operator : Mike

Inj Volume : $1 \mu 1$

Acq. Method : C: \HPCHEM $\backslash 2 \backslash$ METHODS $\backslash$ MATT .M

8/26/2006 10:53:06 AM by Mike (modified after loading)

Analysis Method : C: \HPCHEM \2\METHODS \D3087.M

Last changed : 9/2/2006 12:02:15 PM by Mike (modified after loading)

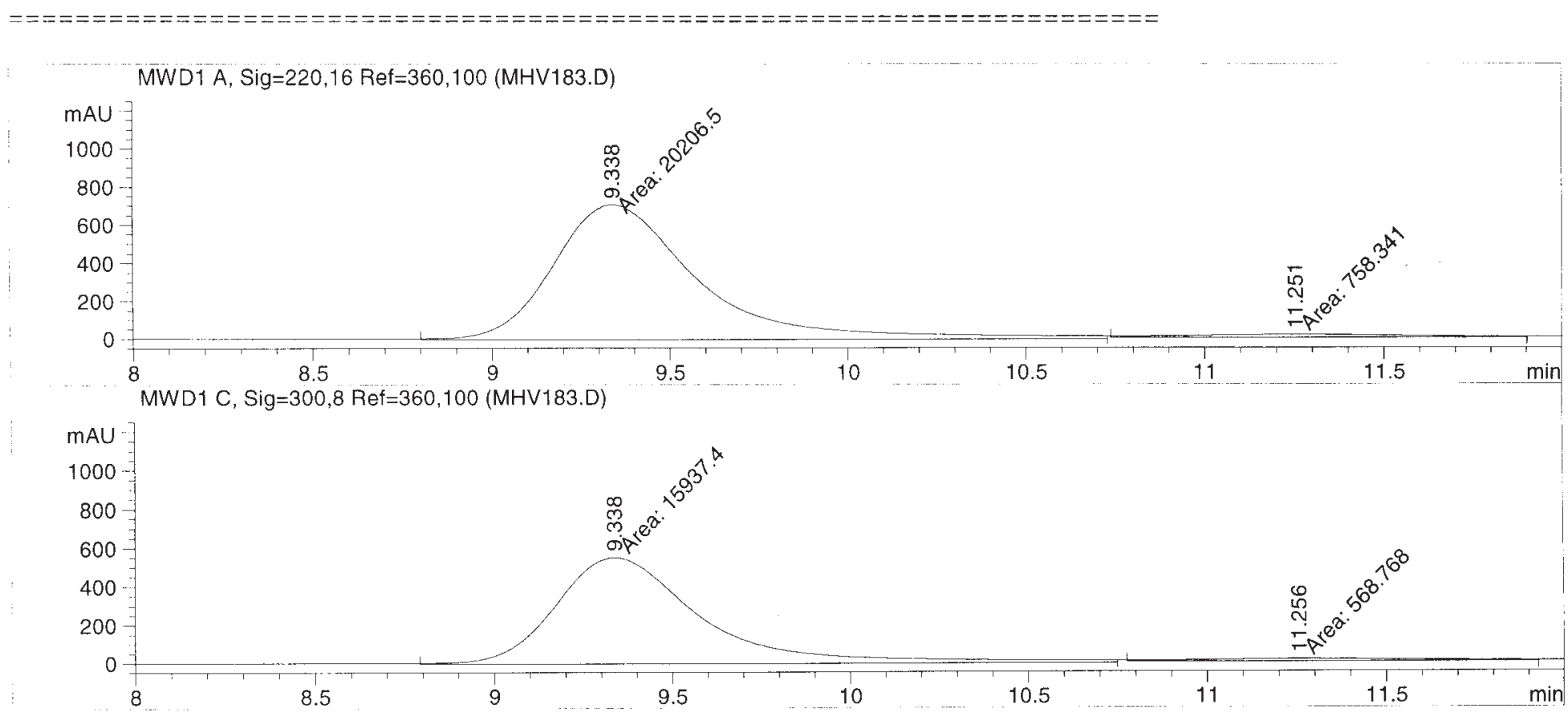

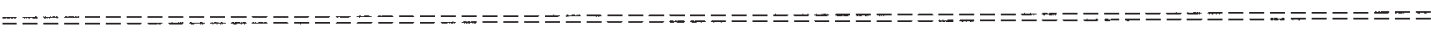

Area Percent Report

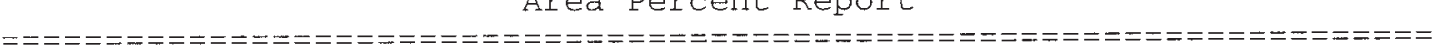

Sorted BY

Multiplier

Dilution

Use Multiplier \& Dilution Factor with ISTDs
$\mathrm{S} 80 / \mathrm{S} 80$ 